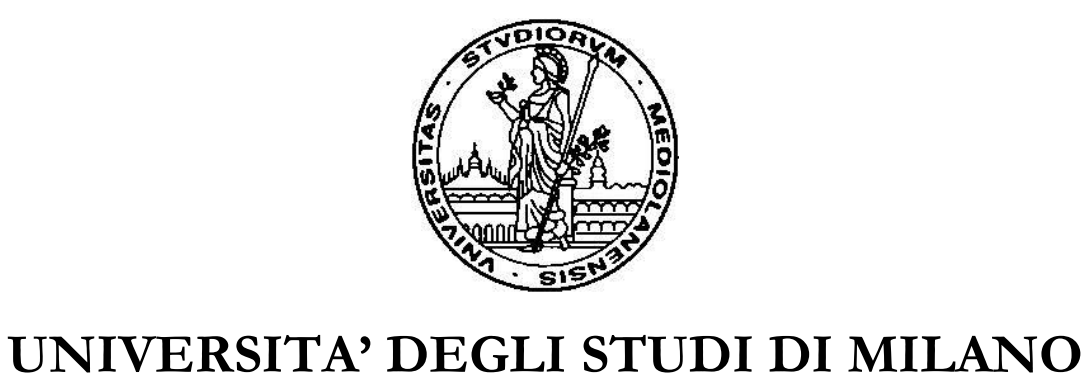

Faculty of Veterinary Medicine

Department of Animal Science

Doctoral Course in Biotechnology Applied to

Veterinary and Animal Sciences

Coordinator: Prof. Fulvio Gandolfi

\title{
ISOLATION, CHARACTERIZATION AND \\ DIFFERENTIATION ABILITY OF CARDIAC PROGENITOR CELLS IN ADULT PIGS
}

Arianna Vanelli

Student NR: R08037

Supervisor: Prof. Tiziana A.L. Brevini 


\section{$\underline{\text { Index }}$}

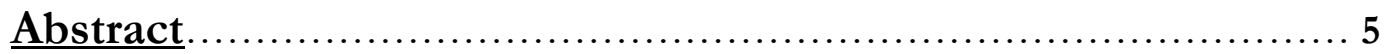

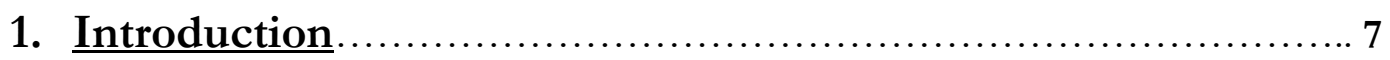

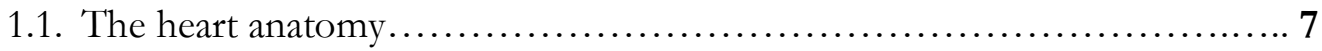

1.2. Development of the embryonic heart............................... 12

1.3. Cardiac development pathways.................................. 16

1.4. Self-renewal, pluripotency and differentiation ability of stem cells.......... 20

1.5. Cardiac diseases................................................... 29

1.5.1. Cardiomyopathies......................................... 29

1.5.2. Ischemic cardiomyopathy..................................... 31

1.5.3. Valvular heart disease........................................... 34

1.5.4. Congenital heart defects....................................... 35

1.6. Cardiac stem cells available for heart therapy......................... 36

1.6.1. Embryonic stem cells........................................... 37

1.6.2. Cardiac stem cells................................................ 41

1.6.3. Adult cardiac progenitor cells................................... 44

1.6.4. Isl1 ${ }^{+}$cardioblasts................................................ 45

1.6.5. Mesoangioblasts.......................................... 46

1.6.6. Cardiac mesoangioblasts......................................... 48

1.6.7. Mesenchymal stem cells........................................ 50

1.6.8. Skeletal myoblast cells............................................ 51

1.6.9. Bone marrow-derived progenitor cells............................... 51 
1.6.10. Endothelial and epicardial progenitor cells....

1.7. Cardiac stem cells available in large animal models.....................54

1.8. Which animal for which pathology? ................................6 60

1.9. Murine models for cardiac diseases................................6 63

1.10. Porcine models for cardiac diseases............................67 67

2. Aim of the research...................................... 71

3. Materials and methods................................... 74

3.1. Isolation and culture of Pig Adult Cardiac Progenitors.................. 74

3.2. Analysis of Pig Adult Cardiac Progenitor proliferation ability.............. 77

3.3. Karyotype analysis of Pig Adult Cardiac Progenitors....................... 78

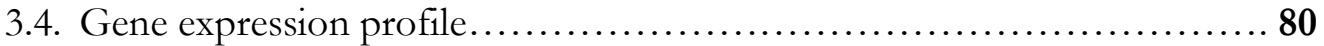

3.4.1. $\mathrm{RN} A$ extraction................................................ 80

3.4.2. $\mathrm{RN} A$ reverse transcription ..................................... 82

3.4.3. Polymerase Chain Reaction (PCR) .............................. 83

3.4.4. Pig Adult Progenitor gene expression .................................. 84

3.5. Characterization of Pig Adult Cardiac Progenitors surface markers........................................................ 88

3.6. Pig Adult Cardiac Progenitor differentiation ability.................... 90

3.6.1. Cardiac differentiation ......................................... 90

3.6.2. Smooth muscle differentiation......................................90

3.6.3. Skeletal muscle differentiation ...................................... 91

3.7. Immunocytochemistry and immunofluorescence..................... 92 
3.8. Pig Adult Cardiac Progenitors cocultured with fetal rat cardiomyocytes 94

3.9. Data analysis. .95

4. Results. 96

4.1. Isolation and proliferation ability of Pig Adult Cardiac Progenitors 96

4.2. Karyotype analysis of Pig Adult Cardiac Progenitors. 99

4.3. Characterization of Pig Adult Cardiac Progenitors surface markers 101

4.4. Gene expression analysis of Pig Adult Cardiac Progenitors.... 105

4.5. Differentiation ability of Pig Adult Cardiac Progenitors 108 4.5.1. Analysis of Pig Adult Cardiac Progenitor ability to differentiate into smooth muscle. 108

4.5.2. Analysis of Pig Adult Cardiac Progenitor ability to differentiate into skeletal muscle. 109

4.5.3. Analysis of Pig Adult Cardiac Progenitor ability to differentiate into cardiomyocytes.

4.6. Fusion ability of Pig Adult Cardiac Progenitors....

5. Discussion.

6. References.

7. Appendix 185

8. Acknowledgements. 


\section{$\underline{\text { Abstract }}$}

Cardiac progenitor cells have been recently identified in the post-natal heart. However, the experiments carried out so far were predominantly performed on mice and humans. Considering the potential future application of these cells for human cell therapy, we propose the pig as an intermediate preclinical model, due to the morphological and functional affinity of the porcine species with the human. Pig adult cardiac progenitors were isolated from explants of adult pig hearts and cultured in complete DMEM medium. Cells were analyzed for their expansion ability and for the expression of surface markers. All lines were positive for CD44 and CD34. Only a small percentage of cells expressed CD31, while screening for CD45 gave a negative result in all the lines obtained, regardless to their origin. Molecular characterization was performed using primers designed for pluripotency, mesenchymal and cardiac related genes. These cells were shown to actively transcribe for c-kit, Oct4, Gata6, CD31, CD34, CD44, Mesp1, Mesp2, Mef2a, Nkx2.5, ANP, Cx43, Cardiac Actinin, Tbx5 and Tbx18. Staining with Desmin, Connexin43, MF20, Rhodamine Phalloidin, $\alpha$-Tropomyosin and Smooth Muscle Actin antibodies demonstrated that adult pig cardiac progenitors could differentiate into cardiomyocytes and smooth muscle cells, when exposed to the appropriate inducing media. Fusion experiments revealed that pig cardiac progenitor cells 
have the ability to fuse with fetal rat cardiomyocytes, reflecting a distinct property common to many types of cardiac progenitors. The data obtained indicate that adult porcine cardiac progenitor cells can be isolated and cultured in vitro. These cells display a high molecular affinity and share many differentiation properties with a cardiac progenitor cell population recently described in weanling pigs. This suggests that cardiac progenitors, although more abundant and functional in the neonatal and post weaning period, are present and active in adult porcine hearts and may represent an interesting tool for preclinical and translational studies of stem cell-based cardiovascular therapy. 


\section{Introduction}

\subsection{The heart anatomy}

The heart is the central organ that by rhythmic contraction pumps blood continuously through the blood vessels. It is a hollow organ located in the chest cavity above the diaphragm between the two lungs. It's contained in the connective tissue, the fibrous pericardium, and lined by a serous membrane, the serous pericardium. The interior has four chambers: two upper atria, right and left, and two lower ventricles, right and left.

The right pump receives deoxygenated (venous) blood from the body and ejects it into the pulmonary trunk, which carries it to the lungs for reoxygenation; the left pump receives the oxygenated (arterial) blood from the lungs and ejects it into the aorta, which distributes it once more to the body. The right atrium communicates with the right ventricle through an atrioventricular opening with a valve, called tricuspid valve, which is composed of three cusps that attach to a fibrous ring that encircle the opening. Similarly, the left atrium communicates with the left ventricle through an atrioventricular opening with a valve, called bicuspid or mitral valve, which generally has only two major cusps. The atrioventricular valves are intended to flush the blood from the ventricle during atrial systole and 
prevent blood reflux from the ventricle to the atrium during ventricular systole.

The right atrium receives blood effluent from the general circulation by the two venae cavae and the coronary sinus. The caudal vena cava enters the caudodorsal part of this chamber, above the opening of the much smaller vein, the coronary sinus that drains the heart itself. The cranial vena cava opens craniodorsally at the terminal crest.

The left atrium has generally a similar form. It receives the pulmonary veins, which enter at 2 sites (craniosinistral and craniodextral).

The right ventricle receives venous blood from the atrium and pumps it to the lungs through the pulmonary artery. The pulmonary artery opening is located at the base of the ventricle, more anteriorly and higher than the atrioventricular opening and has 3 semilunar valves, characterized by a small fibrous dimple, which allows the complete closure of the orifice during the ventricular diastole. The right ventricle walls are irregular due to the various muscle protrusions, the trabeculae carneae, which in some cases (papillary muscles) reach with thin tendons, the chordae tendineae, the tricuspid valve flaps.

The left atrium receives oxygenated blood returning from the lungs through four pulmonary veins, which are devoid of valvular apparatus. The medial wall corresponds to the interatrial septum, the anterior wall is irregular due to the 
presence of muscular trabeculae and the lower wall is characterized by bicuspid or mitral valve orifice.

The left ventricle receives oxygenated blood, reflued from the lungs, and pumps it into the systemic circulation through the aorta. The aorta orifice is located at the base of the left ventricle, in the anterior-medial position respect to the mitral valve orifice. The aorta orifice has three semilunar valves similar for morphology and function to the pulmonary artery orifice. The left ventricle walls have an irregular appearance due to the presence of numerous trabeculae carneia that intersect each other. As the right ventricle, the trabeculae carneia are different and between them the papillary muscles send the tendon chordae to the valve cusps.

The heart wall consists of three overlapping layers from the inside out that are the endocardium, myocardium and epicardium. The endocardium is the innermost layer of the tissue that lines all the heart chambers. The epicardium is a double-walled sac that contains the heart and the roots of the great vessels. The pericardial sac has two layers: the outermost fibrous pericardium and the inner serous pericardium. The serous pericardium, in turn, is divided into two layers, the parietal pericardium, which is fused to and inseparable from the fibrous pericardium, and the visceral pericardium, which is part of the epicardium. The epicardium is the layer immediately outside of the heart muscle proper, namely the myocardium. The myocardium is the heart muscle 
itself and varies in thickness depending on its location, being thin in the atria and thick in the ventricles. The myocardium is divided into common and specific myocardium. The common myocardium allows the heart to contract and is composed of single striated muscle fibers, namely the cardiomyocytes interconnected each other by intercalated discs. The specific myocardium has instead the function to conduct the contraction impulse along specific directions and consists of globular cells with a few myofibril bundles that are organized into two conduction systems, the sinuatrial system and the atrioventricular system.

The system begins with the sinuatrial node, a specific cluster of myocardial cells, located at the top of the right atrium, near the superior vena cava orifice. The sinuatrial node generates spontaneously action potentials that propagate through conduction fibers to the common myocardium of the wall atria. The sinuatrial node function thanks to the presence of specific channels, called HCN channels (Hyperpolarization-activated cyclic nucleotide-gated), through which passes an inward current of potassium ions $\left(\mathrm{K}^{+}\right)$able to induce depolarization (Di Francesco et al. 1986). The intensity and frequency of the inward current is governed by the hyperpolarization potential and by the intracellular concentration of cAMP. Cardiomyocytes during diastole has a hyperpolarized potential that stimulates the activation of $\mathrm{HCN}$ channels and, therefore, the initiation of an action potential. $\beta$-adrenergic stimulation 
increases the heart rate but decreases the vagal stimulation, increasing and decreasing, respectively, the intracellular concentration of cAMP and, consequently, the level of HCN channels activation.

The atrioventricular system begins with the atrioventricular node, localized in the medial wall of the right atrium, near the coronary sinus orifice. From the node starts a bundle of specific myocardial cells, known as the bundle of His, which reaches the interventricular septum and, arrived in the muscular portion of the septum, is divided into two branches. Each branch runs in the interventricular septum to the apex and then backs in the papillary muscles. At this level, branches ramify into Purkinje networks that go back to the base of the ventricles (Figure 1) (Dyce, Sack and Wensing, Textbook of Veterinary Anatomy, 1987).
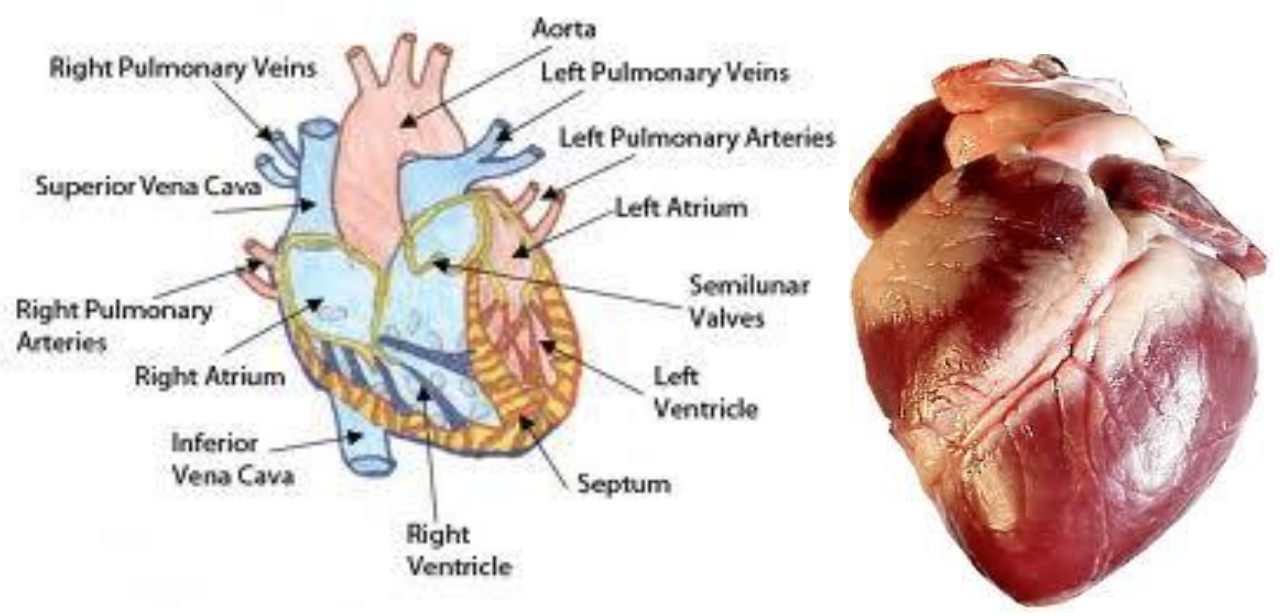

Figure 1. Pig heart anatomy. 
1.2 Development of the embryonic heart

Heart and vascular system development begin very early in the mesoderm both within (embryonic) and outside (extra embryonic) the embryo. The heart forms initially in the embryonic disc as a simple paired tube inside the forming pericardial cavity, which, when the disc folds, gets carried into the correct anatomical position in the chest cavity. During gastrulation, cells migrate to the embryo so as to be arranged in three layers: ectoderm, mesoderm and endoderm (Gilbert SF. 2000, Developmental Biology, 6th edition). In mammals, the mesoderm forms by the ingression of epiblast cells through the primitive streak. Cells exiting at the posterior end of the primitive streak move into the extra-embryonic region where they give rise to a mesodermal lineage (allantoids, amnion and blood islands of the yolk sac). By contrast, cells located in more anterior regions of the streak remain inside the embryo proper and produce the paraxial, intermediate and lateral plate mesoderm of the future trunk (Bachiller et al. 2003).

The mesoderm can be divided into five regions:

1) Cordamesoderm, which forms the notochord, a transient organ whose major functions include inducing the formation of the neural tube and establishing the anterior-posterior body axis (Gilbert SF. 2000, Developmental Biology, 6th edition); 
2) Paraxial mesoderm (or somitic dorsal mesoderm), which forms somites, blocks of mesodermal cells on both sides of the neural tube that will produce many of the connective tissues of the back (bone, muscle, cartilage, and dermis). The term dorsal refers to the observation that the tissues developing from this region will be in the back of the embryo, along the spine (Gilbert SF. 2000, Developmental Biology, 6th edition);

3) Intermediate mesoderm, from which form the urinary system and genital duct (Gilbert SF. 2000, Developmental Biology, 6th edition);

4) Lateral plate mesoderm, which gives rise to the heart, blood vessels, and blood cells of the circulatory system, as well as to the lining of the body cavities and to all the mesodermal components of the limbs except the muscles. It will also form a series of extra embryonic membranes that are important for transporting nutrients to the embryo (Gilbert SF. 2000, Developmental Biology, 6th edition);

5) Head mesenchyme, which contributes to the connective tissues and musculature of the face (Scott et al. 1997; Gilbert SF. 2000, Developmental Biology, 6th edition).

The heart, therefore, arises from cardiac progenitor cells located in two regions of the visceral mesoderm that growing extend cranially and laterally. Subsequently, the cardiac progenitors migrate into the ventral position to form 
the cardiac tube that is composed of two layers, the endocardium and the epicardium. The cardiac tube, therefore, go against a series of events, for which the heart takes a spiral shape with the atria precursor region over the ventricles precursor region. Meanwhile, at the atrioventricular canal level endocardial cushions are formed, which refers to a subset of cells in the primordial heart that play a fundamental role in the proper heart septation. During this phase, there is also the formation of trabeculae, myocytes layer along the inner surface of the ventricle and interventricular septa. Finally, in the remodeling process, the heart is divided into four rooms through the formation of septa, consisted for the most part of muscle structures and atrioventricular cushions. Septa have cracks that permit the blood to pass across the heart, allowing the embryo survival. With the first breath, these cracks close completely, permanently separating the right circulatory system from the left circulatory system (Moorman et al. 2003; Anderson et al. 2003; Harvey et al. 2003).

Two processes are responsible for the formation of new blood vessels: vasculogenesis and angiogenesis (Vailhé et al. 2001). Vasculogenesis refers to the de novo formation of blood vessels from mesoderm (Pardanaud and Eichmann 1998). This process occurs in the intestine, lung, aorta and in the visceral mesoderm surrounding the yolk sac. The mesoderm of these organs contains cells, called angioblasts, able to organize themselves into capillaries 
then take contact with the vessels of greater caliber. The main growth factors that promote vasculogenesis are: FGF2 (Basic Fibroblast Growth Factor), which is necessary for the formation of angioblasts from mesoderm (Ribatti et al. 1995); VEGF (Vascular Endothelial Growth Factor), which promotes the differentiation of angioblasts into vascular endothelium (Hoeben et al. 2004); Angiopoietin-1 that mediates the interaction between endothelial cells and the surrounding smooth muscle (Ferrara et al. 1996; Vikkula et al. 1996). Angiogenesis consists rather in the formation of new blood vessels from existing vessels (Allen and Wilson 1993; Risau et al. 1988). The developing organs release angiogenic factors that induce endothelial cells to proliferate and migrate to form new blood vessels inside the organ. The embryo blood vessel system is organized so that the umbilical vein bring into the heart oxygenated nutrient-rich blood, which is pumped in the aortic arches and then to the entire embryo. At the same time, the umbilical artery leads to the placenta the waste products. 
1.3 Cardiac development pathways

The heart development is controlled by a series of factors that activate the expression of cardiac transcription factors and are essential for proper organogenesis (Figure 2).

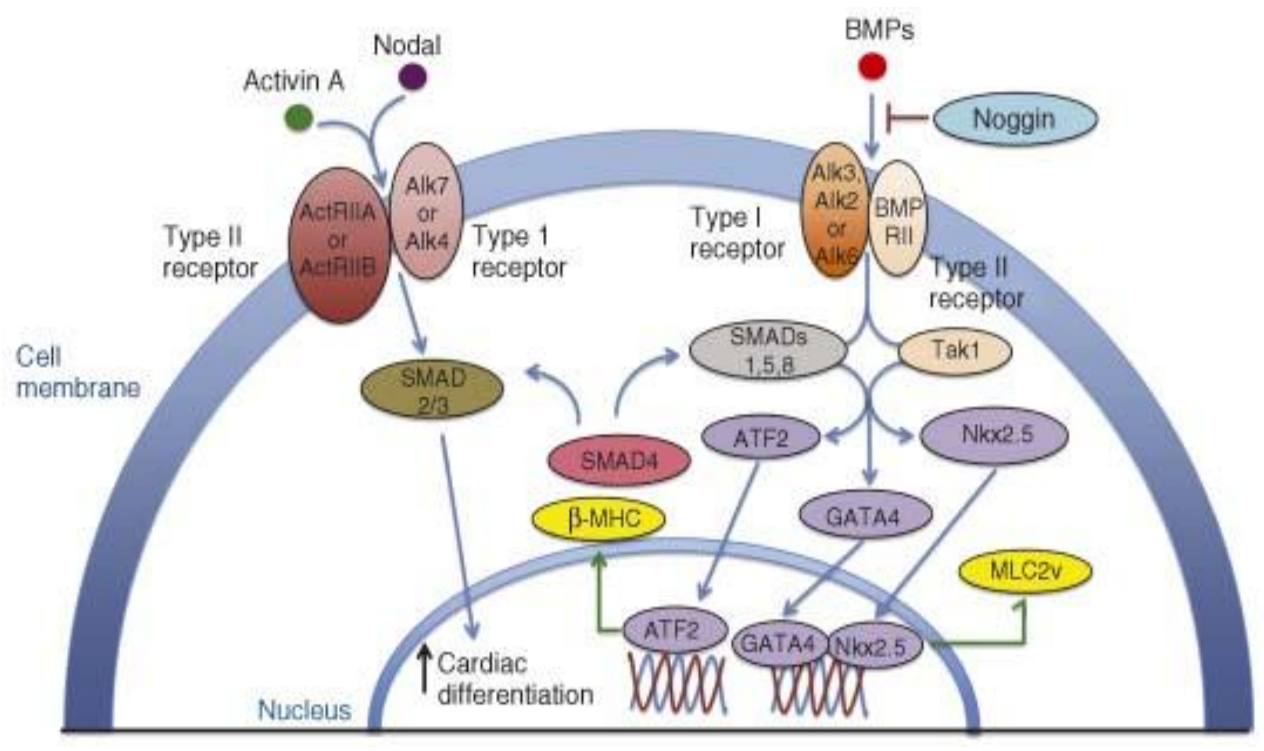

Figure 2. Cardiogenic pathways (Young et al. 2010).

Among these, the BMP (Bone Morphogenetic Protein) signaling has a key role in specifying and maintaining the cardiac lineage. BMP family members are expressed in the endoderm, which is in close association with the cardiac mesoderm. BMP active receptors promote the expression of Smad transcription factors, which, in turn, induce the expression of cardiac genes 
(Schultheiss et al. 1997; Andree et al. 1998; Schlange et al. 2000; Schwartz and Olson 1999; Searcy et al. 1998; Lien et al. 2002).

FGF8 is involved in cardiogenesis and, together with transcription factors basic helix-loop-helix Mesp1 and Mesp2 (mesoderm posterior 1 and 2), stimulates the migration of cardiac precursors (Kitajiama et al. 2000).

Notch signaling remains restricted to the potential cardiac precursors cardiomyogenic and adjusts the timing of their differentiation (Rones et al. 2000).

The main and best-known transcription factors that activate the differentiation program of cardiac precursors are GATA4, Nkx2.5, Tbx5 and Mef2.

GATA4 belongs to the family of GATA transcription factors that regulate the expression of many genes interacting with the consensus sequence WGATAR through a DNA binding domain that consists of two zinc finger motifs (Whyatt et al. 1993). The GATA family consists of 6 isoforms: GATA1, 2, 3 are not redundant and are expressed specifically in the hematopoietic system (Tsai et al. 1994; Pandolfi et al. 1995; Fujiwara et al. 1996). GATA4, 5, 6 are restricted to the heart and intestines (Kelley et al. 1993; Grepin et al. 1995; Laverrière et al. 1994; Jiang and Evans 1996). GATA4 is able to activate the expression of numerous cardiac genes, often acting as a cofactor. In particular, one of the most important interactions for the development rate is between GATA4 and Nkx2.5: the binding of GATA4 to the Nkx2.5 C-terminal 
domain induces a conformational change that unmasks the Nkx2.5 activation domain (Figure 3). The activation of Nkx2.5 is responsible for the expression of several cardiac genes including ANF (Atrial Natriuretic Factor), $\alpha$-cardiac actin and MHC (Myosin Heavy Chain) (Durocher et al. 1997; Peterkin et al. 2003).

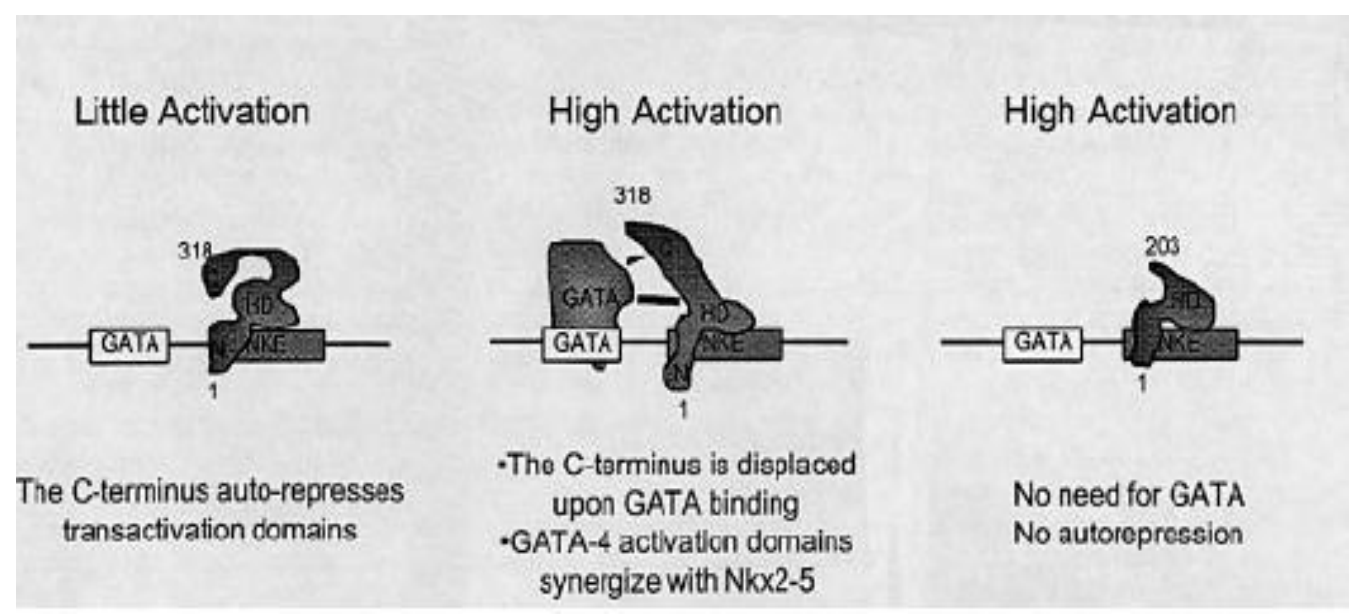

Figure 3. Interactions between GATA4 and Nkx2.5.

Mef2 proteins are expressed at high levels in all muscle cells. The 4 Mef2 isoforms, Mef2a, Mef2b, Mef2c and Mef2d form homo- and heterodimers able to interact with DNA at the consensus sequence $(\mathrm{T} / \mathrm{C}) \mathrm{TA}(\mathrm{A} / \mathrm{T})_{4} \mathrm{TA}(\mathrm{G} / \mathrm{A})$ present in the promoters of several muscle specific genes. Several evidences indicate that Mef2 proteins have a critical role in regulating the differentiation of the all three muscle lines (Lin et al. 1997; Bi et 
al. 1999). The role of Mef2 has been studied mainly in skeletal muscle, where it acts as a cofactor of the myogenic proteins bHLH (basic Helix-Loop-Helix) MyoD, Myf5, myogenin and MRF4 (Kaushal et al. 1994; Molkentin et al. 1995). Numerous cardiac genes contain the binding site for Mef2 proteins, including MLCV2V (Ventricular Myosin Light Chain), cardiac troponin T, cardiac troponin I, MHC (Myosin Heavy Chain) and Desmin (Iannello et al. 1991; Molkentin and Markham 1993; Kuisk et al. 1996; Di Lisi et al. 1998). Mef2 has a low affinity for cardiac promoters and is recruited at the level of promoter sequences from the GATA transcription factors. The physical interaction between GATA4 and Mef2, in particular, enhances the expression of cardiac genes (Zang et al. 2004).

Finally, the transcription factor $\mathrm{Tbx} 5$ is added to the complex GATA4/Nkx2.5 increasing the transcription levels of the cardiac differentiation genes (Garg et al. 2003). Additional Tbox genes, including Tbx2, Tbx3, Tbx18 and Tbx20 are expressed in distinct compartments of the developing heart (Ryan and Chin 2003). Together, these T-box genes likely contribute to cardiac lineage determination, chamber specification, valve formation, epicardial development and specialization of the conduction system (Plageman et al. 2005). T-box genes, including Tbx18 and Tbx5 are also expressed in the epicardial cell layer of the heart and its progenitors (Kraus et al. 2001; Hatcher et al. 2004; Tanaka and Tickle 2004). 
1.4 Self-renewal, pluripotency and differentiation ability of stem cells

Stem cells are defined by both their ability to make more stem cells, a property known as 'self-renewal', and their ability to produce cells that differentiate. One strategy by which stem cells can accomplish these two tasks is the asymmetric cell division, whereby each stem cell divides to generate one daughter cell with a stem-cell fate (self-renewal) and one daughter cell that differentiates. Stem cells can also use symmetric divisions to self-renew and to generate differentiated progeny. Symmetric divisions are defined as the generation of daughter cells that are destined to acquire the same fate (Morrison and Kimble 2006). Symmetric divisions are observed especially at the early stages of embryonic development in order to increase the cell mass of the embryo. Asymmetric division, however, is typical of embryonic stem cells in the later stages of development and of adult stem cells in order to ensure the homeostasis of the organs (Figure 4). The information about the molecular mechanisms of self-renewal and pluripotency are not well known. 


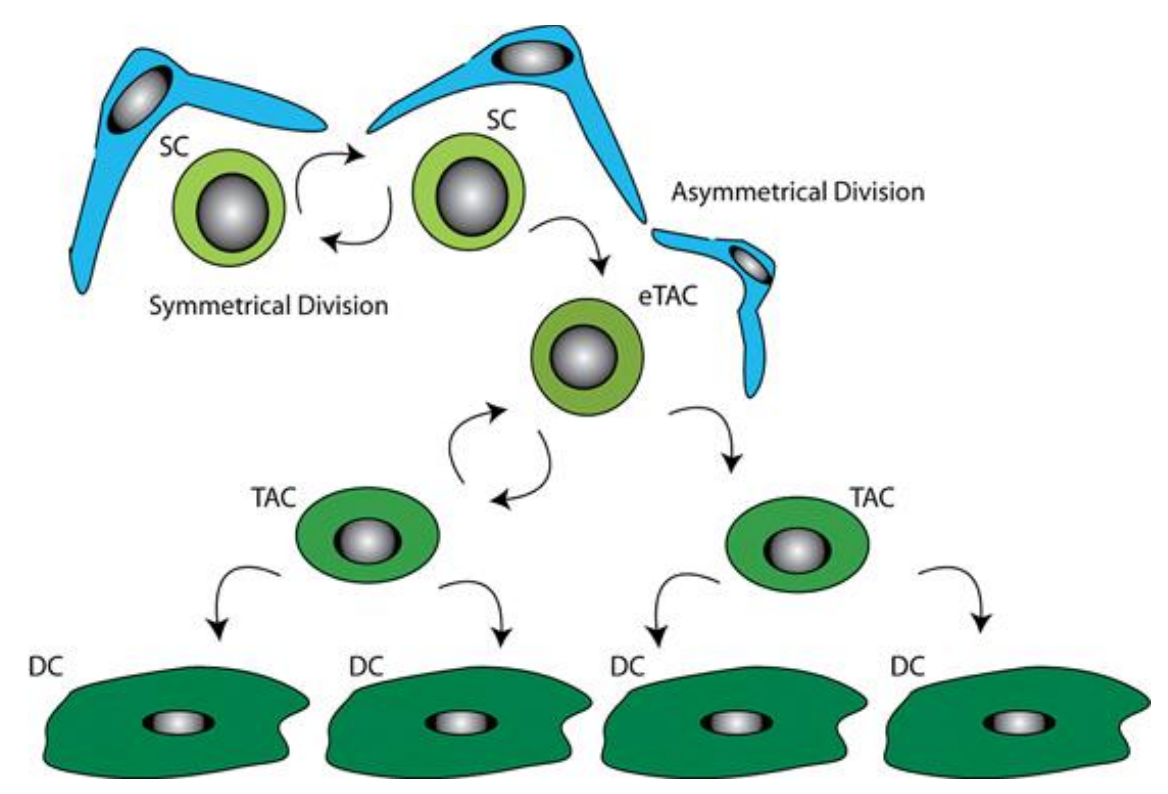

Figure 4. Illustration of stem cell control by the niche (Secker et al. 2009).

One of the most studied pathways is the cytokine LIF (leukemia inhibitory factor). LIF is a cytokine of the family of interleukin-6 produced by fibroblasts that can regulate cell cycle progression and maintain the pluripotent ability of embryonic stem cells. LIF acts on the LIF receptor (LIFR) that belongs to the family of cytokines class I receptors: at the extracellular level consists of fibronectin and at the intracellular level contains, instead, three domains, called box1, 2 and 3, responsible for signal transduction (Taga et al. 1997; Patthy et al. 1990, Bazan et al. 1989, Bazan et al. 1991). The receptor activation determines the activation of the tyrosine kinase receptor associated with the Box regions, which phosphorylate a number of transcription factors that 
promote the expression of the pluripotent genes. Among these, the most important are STAT1 and STAT3 (Latent Factors Transcription Transmitting Signals), ERK1 and ERK2 (Extracellular Signal Receptor Kinase), MAPK (Mitogen Activated Kinases), Grb2 (Growth Factor Receptor Bound Protein) and Gab1 (Grb2 Associated Protein Binder) (Heinrich et al. 1998; Vanhaesebroeck and Alessi 2000). Besides, among the genes regulated by the LIF pathway, Oct4 transcription factor is the key of the pluripotency. The target genes of Oct 4 can be divided into three groups: those activated by Oct 4 and its cofactor Sox-2 (FGF4, Utf1, Fbx15 and Lefty1) (Yuan et al. 1995; Nishimoto et al. 1999; Tokuzawa et al. 2003); those repressed by Oct4 (a-hCG and b-hCG) (Pesce et al. 2001) and those activated by Oct4 but also repressed by a squelching mechanism when Oct4 is over expressed (Rex1) (Niwa et al. 2000; Niwa et al. 2001; Matoba et al. 2006).

It was recently highlighted the importance of another pluripotent transcription factor: Nanog. Nanog knockout embryos die soon after implantation because the epiblast of these embryos is not pluripotent but have a differentiation potential restricted to the endodermal cell line. Similarly, the inactivation of Nanog in embryonic stem cells results in the differentiation to the extra embryonic endoderm layer of the visceral and parietal yolk sacs (Chambers et al. 2003; Mitsui et al. 2003; Theunissen and Silva 2011). Another particular aspect of a stem cell is the different cell cycle progression in contrast of that of 
a somatic cell, which is primarily regulated at the G1 phase by the RB (retinoblastoma protein) and the Myc pathway. In embryonic stem cells, the cyclin-CDK complexes (Cyclin Dependent Kinase) are constantly active and require no adjustment. The regulation of $\mathrm{G} 1$ phase mediated by the $\mathrm{RB}$ pathway is required only during differentiation (Savatieret al. 1996; Wianny et al. 1998; Sherr and Roberts 1995). The high proliferative rate of embryonic stem cells is also due to the fact that the cell cycle progression is independent from the action of mitogenic factors, such as the Ras/ERK pathway (Burdon et al. 1999; Jirmanova et al. 2002; Schratt et al. 2001). The stem cells proliferative ability is also independent of the PI3K signaling kinase that activates PKB by phosphorylation, which increases the cyclin D1 degradation level and increases the expression levels of the p27 inhibitor (Ojaniemi et al. 2003). During embryonic development, the embryonic stem cells give way to adult stem cells that colonize the various tissues and organs. The formation of various cell types is completed after birth. Nevertheless, many tissues have a pool of multipotent adult stem cells able to ensure the homeostasis of the host tissue (Schofield and Weightman 1978).

Adult stem cells reside within niches that protect stem cells. Niches are composed not only of stem cells but also of differentiated cells that retain some stem cells within the niche while, on the other hand, exposed stem cells to a series of signals that control their pluripotency. The microenvironment of 
the niche is characterized by numerous signals, including factors secreted by stem cells and cell-cell interactions mediated by integral membrane proteins (integrins, cadherins) and the extracellular matrix (Figure 5). The cell adhesion mediated by cadherins is crucial for the organization and maintenance of stem cells within the niche. Among the signals within the niche, the adhesion to the extracellular matrix, mediated primarily by integrins, plays a fundamental role in maintaining stem cells contained in the niche. For example, high expression levels of $\beta 1$ integrin are required for the maintenance of epidermal stem cells where $\beta 1$ integrin regulates the differentiation of keratinocytes and other cell types through the MAP kinase signaling. Integrins also properly localize cells within the tissue and an altered integrin expression in the niche induces stem cells differentiation or apoptosis (Jensen et al. 1999, Zhu et al. 1999, Quesenberry and Becker 1998). In addition, integrins play a role in signaling by activating a series of growth factors receptors (Moro et al. 1998). 


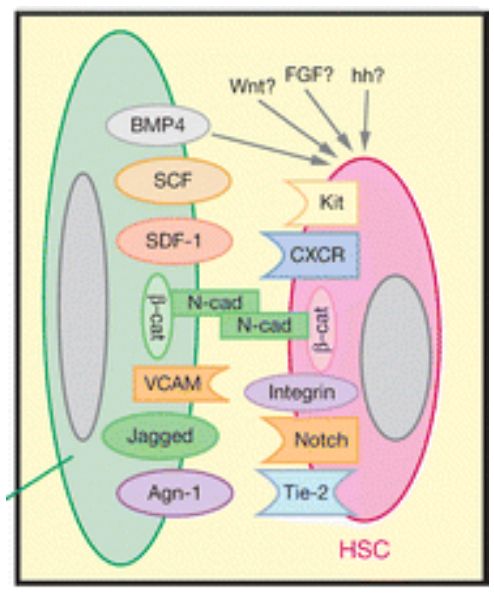

Figure 5. Niche signals (Li and Xie 2005).

The niche, therefore, protects stem cells from differentiation. So, the strategy used by stem cells to generate a differentiated progeny is to follow the asymmetrical division according to a specific polarity axis and a precise orientation of the mitotic spindle that allow one of the daughter cells to become external of the niche in an environment that promotes differentiation (Li and Xie 2005). Stem cells progeny in the niche is surround by an environment specific of a certain type of tissue, characterized, therefore, by the presence of factors that induce the differentiation into cell types typical of the tissue. But it has been shown that, adult stem cells are multipotent, so they are able to differentiate into cells of other tissues and organs (Brazelton et al. 2000; Mezey et al. 2000; Krause et al. 2001; Lagasse et al. 2000; Clarke et al. 2000; Bjornson et al. Science 1999; Ferrari et al. 1998; Orlic et al. 2001; Blau et al. 2001). 
The multipotent mechanisms are the subject of a debate between those who argue that adult stem cells transdifferentiate by fusion and those who argue that the transdifferentiation is fusion independent. Cell fusion of two cells that have several states of differentiation generates a hybrid cell that loses the differentiating features of fused cells and, therefore, can be reprogrammed. Nygren and colleagues have shown that transplanting unfractionated marrow cells labeled with GFP under the control of the $\beta$-actin promoter in the infarcted hearts of transgenic LacZ mice the percentage of GFP positive cardiomyocytes is very low. These cells are also located outside the infarcted area and derive from cell fusion events between the transplanted cells and the cardiomyocytes survived (Nygren et al. 2004).

In contrast, the Anversa's group said that the differentiation of bone marrow cells into cardiomyocytes is independent of cell fusion. In fact, in this set of experiments, $\mathrm{Lin}^{-} / \mathrm{c}^{-\mathrm{kit}^{+}}$cells labeled with GFP and isolated from a donor male were transplanted in the infarcted hearts of female patients. At the damaged level the cells GFP/Y chromosome positive do not express the hematopoietic markers CD45 but expressed, however, specific markers of cardiac differentiation. They are mononuclear and do not possess more than one $\mathrm{X}$ chromosome in addition to the $\mathrm{Y}$ chromosome. These results exclude, therefore, the fusion of transplanted cells with resident cardiomyocytes (Kajstura et al. 2005). 
Recently, a series of molecules that play a fundamental role in the cardiac differentiation processes has been described. These include Notch, which is responsible for the differentiation of various cell types of the ventricle. Notch acts on the cardiac progenitors by inhibiting the expression of heart muscle proteins and activating the expression of markers characteristic of conduction cells, such as SNAP25 and HNK1 (Chau et al. 2006).

Noggin, however, is an antagonist of BMP (Bone Morphogenetic Protein), which, together with Wnt and FGF, is involved in the heart development (Marvin et al. 2001). During the development, Noggin is expressed at high levels but in a transient way in the heart formation region. It has been shown that the inhibition of BMP signaling by Noggin induces mouse embryonic stem cells to differentiate into cardiomyocytes (Yuasa et al. 2005).

Wnt also seems to play a key role in cardiac differentiation. It has been demonstrate that Wnt induces human circulating endothelial progenitors differentiation into cardiomyogenic cells acting along a pathway independent of $\beta$-catenin when cocultured with rat cardiomyocytes (Koyanagi et al. 2005). It was also reported that reactive oxygen species (ROS) generated by the NOX family of NADPH oxidases act as second messengers regulating cell growth and differentiation. In fact, ROS drive early stages of cardiogenesis, as revealed by an impaired cardiac differentiation in the presence of ROS scavengers. Down-regulation of NOX4, the major NOX isoform present during early 
stages of differentiation, suppressed both cardiogenesis and cardiac myofibrillogenesis while $\mathrm{H}_{2} \mathrm{O}_{2}$ could rescue the altered phenotype. Mechanisms of ROS-dependent signaling included p38 mitogen-activated protein kinase (MAPK) activation and nuclear translocation of the cardiac transcription factor myocyte enhancer factor 2c (Mef2c).The active form of Mef2c translocates into the nucleus and promotes the expression of cardiac genes, including sarcomeric proteins ( $\mathrm{Li}$ et al. 2006). 
1.5 Cardiac diseases

Cardiac disease can be divided into five main groups: ischemic cardiomyopathy, chronic cardiomyopathy, valvular disease, myocardial ischemic diseases and congenital disorders.

\subsubsection{Cardiomyopathies}

Cardiomyopathies are a group of heart muscle disease caused by the deterioration of the myocardium function. They are divided into three main groups on the basis of clinical, functional and pathological aspects: dilated (DCM), hypertrophic (HCM) and restrictive (RCM).

DCM is defined by structural hallmarks of left ventricle dilation and increased left ventricle chamber radius-to-wall thickness ratio, resulting in increased left ventricle wall stress (Dixon and Spinale 2009). There are frequent mural thrombi that can give rise to emboli. Sometimes, there is mitral reflux for expansion of the ventricular chamber. Most hypertrophic cells have enlarged nuclei but many are thin and streaked. Varying degree of interstitial and endocardic fibrosis are present and there are often evident fibrous scars. About $40 \%$ of dilated cardiomyopathy cases have no identifiable reasons. 
Other possible causes are genetic or family factors, immunologic abnormalities, viral myocarditis and cytotoxic damage from alcohol.

HCM is a primary myocardial disease that has variable manifestations because the interactions between the many facets of systolic and diastolic dysfunction of the heart are complex (Lin et al. 2002). HCM is characterized by myocardial hypertrophy, abnormal diastolic filling and a good number of cases of obstruction intermittent left ventricular outflow. The disease is inherited in an autosomal dominant fashion. Genes involved in the onset of hypertrophic cardiomyopathy encode for contractile proteins of heart muscle, including myosin heavy chains $\beta$, cardiac troponin $\mathrm{T}, \alpha$-tropomyosin and $\mathrm{C}$ protein bound to myosin. The massive and diffuse left ventricular hypertrophy cause a decrease in cavity volume and a reduced wall compliance with the reduction of diastolic filling, decrease of stroke volume and cardiac failure. This results in an increase of pulmonary venous pressure and left ventricular pressure in the chamber. The most severe complications are atrial fibrillation, mural thrombus formation and possible embolism, ventricular arrhythmias, infective endocarditis of the mitral valve and sudden death.

RCM is defined as heart-muscle disease that results in impaired ventricular filling, with normal or decreased diastolic volume of either or both ventricles but does not affect the contractile function of the ventricle. Systolic function usually remains normal, at least in the early disease, and wall thickness may be 
normal or increased, depending on the underlying cause. The condition usually results from increased stiffness of the myocardium that causes pressure within the ventricle (or ventricles) to rise precipitously with only small increases in volume. RCM can be idiopathic or associated with other diseases affecting the myocardium, in particular actinic fibrosis, amyloidosis, sarcoidosis, metastatic tumors or metabolic disorders (Kushwaha et al. 1997).

\subsubsection{Ischemic cardiomyopathy}

The ischemic cardiomyopathy (IHD) is the consequence of ischemia, namely a situation in which the coronary perfusion is not adequate to the needs of blood required by the myocardium. In most of myocardial ischemia cases, the cause is a change of an atherosclerotic plaque only partially stenotic. Events able to determine the complete coronary artery occlusion are a hemorrhage within the atheroma with increased plaque volume, a breakage or cracking of the plaque with consequent exposure of highly thrombogenic components or an erosion or ulceration of plaque with exposure of thrombogenic constituents of the basement membrane.

The clinical manifestations of IHD are angina pectoris, myocardial infarction, chronic ischemic cardiomyopathy and sudden cardiac death. 
Angina pectoris is characterized by paroxysmal attacks of chest pain caused by transient myocardial ischemia sufficient to cause the infarction. There are three main forms of angina pectoris:

- Stable angina is related to coronary atherosclerosis chronic stenosing responsible of the reduced perfusion. In this condition, increases in metabolic demands make the heart vulnerable to ischemia. Stable angina recedes with rest, leading to a decreased of metabolic demand, or with nitroglycerin that is a potent vasodilator;

- Unstable angina can occur with or without physical exertion and rest or medicine may not relieve the pain. Unstable angina is caused by ulceration or rupture of an atherosclerotic plaque with overlapping of the parietal thrombosis and possible embolization or vasospasm;

- Microvascular Angina, or Angina Syndrome X, is characterized by angina-like chest pain but have different unknown causes, which appear to be the result of poor function in the tiny blood vessels of the heart, arms and legs.

Furthermore, myocardial infarction (MI) is characterized by severe and longterm ischemia that can result in heart muscle death. There are two basic types of acute myocardial infarction: transmural (TMI) and subendocardial infarction (SEI). 
TMI isassociated with atherosclerosis involving major coronary artery. TMI extends through the whole thickness of the heart muscle and are usually a result of complete occlusion of the area's blood supply.

SEI involves a small area in the subendocardial wall of the left ventricle, ventricular septum or papillary muscles. Subendocardial infarcts are the result of locally decreased blood supply, possibly from a narrowing of the coronary arteries. For this reason, the subendocardial infarction may occur in the absence of plaque rupture and thrombosis, or simply be consequent to diffuse stenosing coronary atherosclerosis. Typically, total occlusion of a coronary artery leads to amyocardial infarction. The atherosclerotic plaque modification attracts platelets at the plaque level that adheres to the vessel wall, aggregate and release powerful aggregators such as TXA2, serotonin and platelet factors 3 and 4 that stimulate the vasospasm. At the same time, it is released tissue thromboplastin, which activates the extrinsic pathway of coagulation. Within a few minutes, the thrombus occluded completely the lumen of the coronary vessel considered. Ten $\%$ of myocardial infarction cases are not associated with atherosclerotic thrombosis. Other possible etiologic mechanisms are vasospasm and emboli. In some cases, the heart attack remains unexplained. Sudden cardiac death is caused by lethal arrhythmia. The long-term atherosclerosis, in association with diffuse myocardial atrophy, interstitial 
fibrosis and myocardial scarring, in fact, can damage the conduction system and create an unstable cardiac electro-mechanics condition.

Heart failure is usually a long-term (chronic cardiomyopathy) illness and coincides with the post-infarct heart failure and is associated to hypertrophy.

\subsubsection{Valvular heart disease}

Valvular heart disease is any disease process involving one or more of the valves of the heart (the aortic and mitral valves on the left and the pulmonary and tricuspid valves on the right). Valve problems may be congenital (inborn) or acquired (due to another cause later in life). Treatment may be with medication but often (depending on the severity) involves valve repair or replacement (insertion of an artificial heart valve). Specific situations include those where additional demands are made on the circulation, such as in pregnancy. Pulmonary and tricuspid valve diseases are right-side heart diseases. Pulmonary valve diseases are the least common heart valve disease in adults. Both tricuspid and pulmonary valve diseases are less common than aortic or mitral valve diseases due to the lower pressure those valves experience (MacRae Calum, Genetics of Cardiomyopathy and Heart Failure 2010). 


\subsubsection{Congenital heart defects}

Congenital heart defects are problems with the heart's structure that are present at birth. These defects can involve the interior walls of the heart, valves inside the heart or the arteries and veins that carry blood to the heart or out to the body. Congenital heart defects change the normal flow of blood through the heart. There are many different types of congenital heart defects. They range from simple defects with no symptoms to complex defects with severe, life-threatening symptoms (Peter H. Bruno, Cardiomyopathies: Causes, Effects and Treatment 2008). 
1.6 Cardiac stem cells available for heart therapy

The heart has always been considered a terminally differentiated post-mitotic organ and so unable to renew itself. According to this theory, in the heart tissue there was no population of myocytes able to re-enter the cell cycle and no population of primitive cells that once activated differentiate into cardiomyocytes. The only response to stress is hypertrophy and death of cardiomyocytes. The inability of the heart to regenerate the myocardium has been attributed to the fact that most of the precursors differentiated into cardiac myocytes during the heart development. In fact, the heart is the first organ completely differentiated that formed and function during the embryonic development (Leri et al. 2005). Recently, the identification of different classes of cardiac progenitor cells suggests that the heart may rather contain a stem cell compartment, responsible for both tissue turn-over and regeneration, which follows acute or chronic damage to the cardiac tissue(Beltrami et al. 2003; Oh et al. 2003; Matsuura et al. 2004; Messina et al. 2004; Laugwitz et al. 2005; Pfister et al. 2005; Tomita et al. 2005). A distinct characteristic of cardiogenic cells is that they can be either endogenous or derive from outside the heart itself, can originate as the natural course of their differentiation program (e.g., embryonic stem cells) or can be the result of specific inductive conditions (e.g., mesenchymal stem cells). Why so many cell 
types have a cardiogenic potential, at least in vitro, is not clear. This can reflect the requirement for a specific precursor of each cell types that are found in the heart including cardiomyocytes, endothelial cells, smooth muscle cells, conduction system cells as well as neurons or it can simply mimic the process of cardiac differentiation, where a variety of progenitor cells contribute to new cardiac tissue at different stages of embryonic development. The following are the better-characterized cardiac progenitor cells.

\subsubsection{Embryonic stem cells}

Embryonic stem cells (ES) are pluripotent and able to differentiate into all cell types while adult stem cells are multipotent and can form a limited number of cell types. ES were derived from the inner mass of blastocysts, therefore, in the pre-implantation embryo (Figure 6). 


\section{Pluripotent Stem Cells}

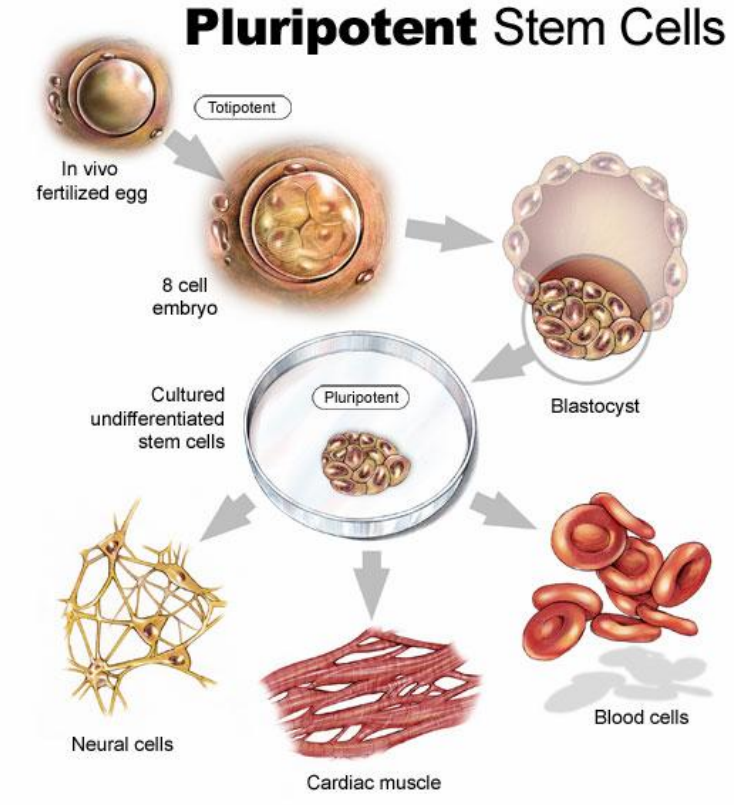

Figure 6. Embryonic stem cell differentiation ability.

The outer layer of the blastocyst, the trophectoderm, is selectively removed by immunosurgery techniques to free the internal mass that is plated on a feeder layer of mouse embryonic fibroblasts non-proliferating (MEF) to form colonies of stem cells embryo, which, on the one hand, are able to proliferate remaining undifferentiated and retaining a stable diploid karyotype and, on the other hand, are able to differentiate in the presence of suitable conditions in the cells of all types of tissues. The most common method for inducing differentiation in vitro is to remove the ES cells from the feeder layer and to grow them in suspension. ES cells begin to differentiate, forming threedimensional aggregates called embryoid bodies (EBs), which are then grown 
on plates pre-coated with gelatin. In this condition, EBs begins to express in different regions several markers specific of embryonic ectoderm, mesoderm and endoderm (Itskovitz-Eldor et al. 2000). Regarding the cardiac differentiation, the EBs formed regions that contract spontaneously. Cells isolated from these regions express transcription factors and proteins specific of cardiomyocytes, including GATA4, Nkx2.5, cardiac troponin I and T, ANP (Atrial Natriuretic Peptide) and MLCs (Myosin Light Chains). Stem cellderived cardiomyocytes are able to integrate functionally into the myocardium of adult mice (Klug et al. 1996).

Embryonic stem cells and, more recently, induced Pluripotent Stem cells (iPS) have been shown to be able to differentiate in vitro into genuine cardiomyocytes (Figure 7) and supportive cardiac cells (Passier et al. 2008; Narazaki et al. 2008) as well as to integrate into heart tissue, improving cardiac function (Yan et al. 2009; Laflamme et al. 2007).
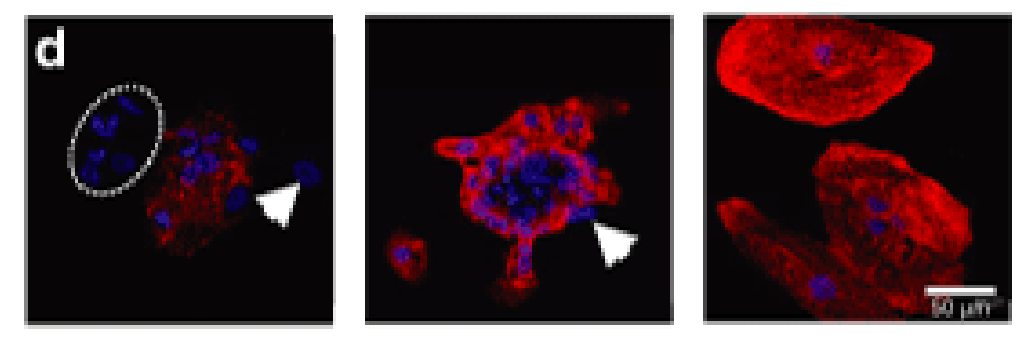

Figure 7. ES differentiation into cardiomyocytes (Anderson et al. 2007). 
However, ES and iPS also have disadvantages that may limit their use in clinical settings. Possibly, the most serious is their propensity to develop teratomas, tumors that contain a variety of different tissues (Nussbaum et al. 2007). Furthermore, ES/iPS cells differentiate into heterogeneous populations, where cardiac cells represent approximately $1 \%$. It is therefore necessary to improve this efficiency and to obtain heart specialized cell types, such as ventricular and atrial myocytes or pacemaker and conduction system cells (Behfar et al. 2008). Finally, grafted ES form a syncytium that usually becomes separated from the myocardium by a layer of fibrotic tissue. This prevents a proper electrical coupling and is a major risk factor for arrhythmias (Laflamme et al. 2007). Most of these limitations, however, could be overcome by the recently reported derivation of induced cardiomyocytes (iCM) (Ieda et al. 2010). These new cells were obtained by transfecting postnatal cardiac fibroblasts with a combination of three developmental transcription factors, such as Gata4, Mef2c and Tbx5. Induced cardiomyocytes express cardiac specific markers and have a gene expression profile similar to cardiomyocytes and contract spontaneously. Since the reprogramming protocol does not involve, in this instance, a pluripotent embryonic-like status, these cells should not have the propensity to develop teratomas. 


\subsubsection{Cardiac stem cells}

It has been documented that small clusters within the ventricles and atria of the adult heart contain a pool of resident cardiac stem-progenitor cells (CSCs) that not only can replenish the cardiomyocytes population (Beltrami et al. 2003; Oh et al. 2003; Matsuura et al. 2004; Messina et al. 2004; Laugwitz et al. 2005; Pfister et al. 2005; Tomita et al. 2005) but are also able to regenerate coronary vessels (Beltrami et al. 2003; Torella et al. 2005). As well as playing an essential role in myocardial regeneration, it is increasingly evident that resident CSCs also play an important role in normal cardiac homeostasis and myocardial response to injury. Moreover, the CSCs likely represent the best candidate cell for long-term reconstitution of lost myocardium either by cell transplantation or through in situ activation (Torella et al. 2005). CSCs are derived from small heart biopsies through a delicate enzymatic digestion that releases round cells, which in turn form round bodies in suspension culture, called cardiospheres. Various evidences suggest that CSCs effectively repair the damaged myocardium, probably because their natural function is to repair proper the damaged myocardium. The intra-coronary injection of CSCs in a mouse model of heart attack, in fact, significantly improves the hemodynamic parameters of the treated mice compared with those not treated. The injected CSCs are able to cross the vessel wall and migrate into the infarcted region and 
to differentiate into vascular and cardiac cells and exert positive paracrine effects (Smith et al. 2007). The new generation of myocytes is distinguished from the rest of the cardiac tissue because they gather in sites surrounded by scar tissue (collagen I and III) and have morphology similar to that of neonatal cells. Instead, in the myocardium surrounding the infarcted area of the injected stem cells formed cardiac myocytes mature indistinguishable from the rest of the cardiomyocytes.

CSCs and their progeny are located within the heart tissue in specific niches and form connections with the supporting cells, fibroblasts and cardiomyocytes (Figure 8). The cardiac niches are arranged in the less mechanical stress regions, mostly at the atria level (Urbanek et al. 2006).

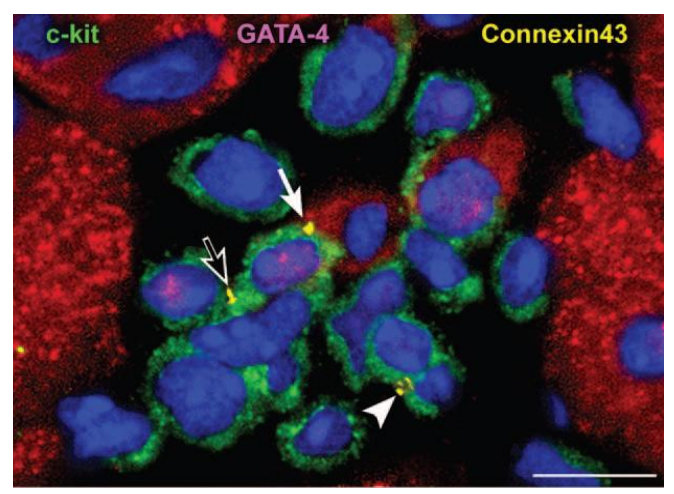

Figure 8. Cardiac niches containing CSCs and putative supporting cells (Urbanek et al. 2006). 
Furthermore, Anversa et al. have isolated from adult myocardium groups of stem cells that express c-kit, MDR1 and Sca-1 markers but do not express transcription factors and proteins specific of cardiomyocytes. Cells positive to c-kit surface antigen are located in small clusters within the ventricles and atria of the adult heart. These cardiac c-kit ${ }^{+}$cells are self-renewing, clonogenic and multipotent, giving rise to a minimum of three different cardiogenic cell lineages: myocytes, smooth muscle cells and endothelial cells (Figure 9) (Beltrami et al. 2003; Rota et al. 2008; Tallini et al. 2008). c-kit ${ }^{+}$CSCs are different from other progenitors because they are negative for CD34, typical of endothelial progenitor cells (EPCs), and CD45, expressed in hematopoietic stem cells. The CSC population also includes cells expressing stem cell antigen 1 (Sca-1) but not c-kit (Oh et al. 2003), a cell population Sca-1-/c-kit-/CD31(Laugwits et al. 2005) as well as another Sca-1+/ c-kit ${ }^{+}$cell type (Matsuura et al. 2004).

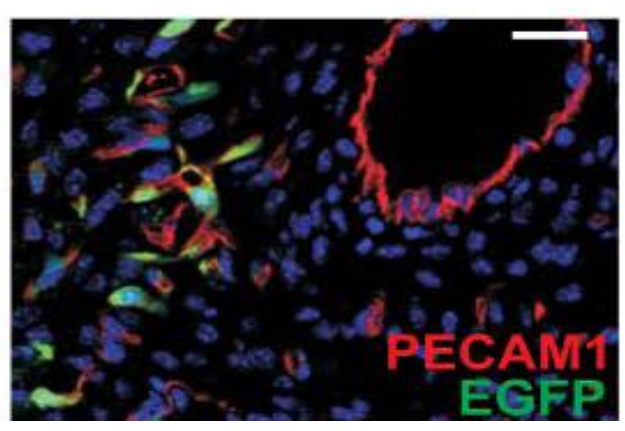

Figure 9. Some $\mathrm{c}-\mathrm{kit}^{+}$cells coexpress PECAM1, indicating endothelial commitment (Tallini et al. 2008). 


\subsubsection{Adult cardiac progenitor cells}

In 2003, Oh's group isolated the Sca- $1^{+}$cardiac progenitors from the adult heart muscle. In particular, cardiomyocytes were separated from the other adult heart cells disrupting the tissue in lethal conditions for most of the cardiomyocytes. The adult heart cells were subsequently analyzed by flow cytometry to assess the expression of different markers. Approximately, 1417\% of analyzed cells expressed Sca-1. Sca-1+ ${ }^{+}$cells are small interstitial cells adjacent to the basal lamina, do not express hematopoietic stem cells markers and do not express c-kit, Flt1, Flk1, vWF and VEC. They express, however, CD31 or its receptor CD38 involved in cell-cell adhesion processes (Figure 10). These cells also show high telomerase activity and express the early cardiac transcription factors, such as GATA4, TEF1 and Mef2c, but do not express the typical genes of mature cardiomyocytes. The Sca- $1^{+}$progenitors differentiate into cardiac mature myocytes in vitro when cultured in the presence of 5'-azacytidine, a demethylating agent that induces differentiation, and if transplanted into a model of myocardial infarction, Sca- $1^{+}$progenitors are able to reach the damaged tissue and to differentiate into cardiomyocytes through fusion event with the survived cardiomyocytes (Oh et al. 2003). 

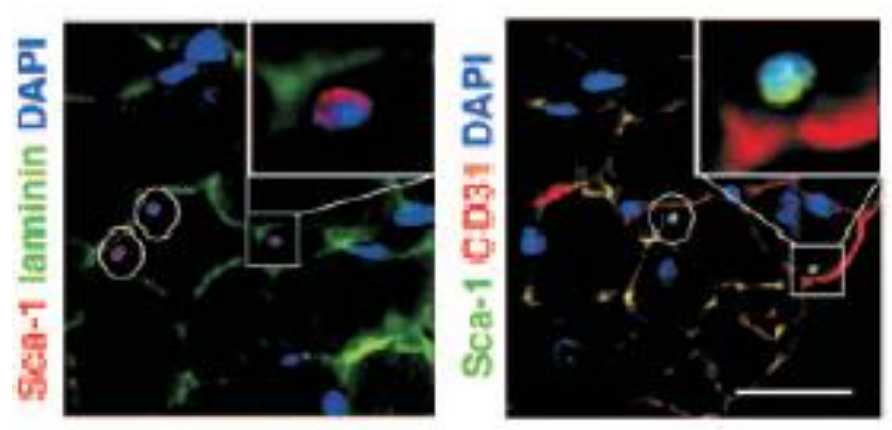

Figure 10. Isolation of Sca- $1^{+}$cells from adult mouse myocardium (Oh et al. 2003).

\subsubsection{Is $11^{+}$cardioblasts}

Cells derived from the secondary heart field during embryonic development persist, in small numbers, in the adult myocardium of different species and are marked by the expression of Islet1 (Isl1) (Chien et al. 2003). Isl1 is a transcription factor characteristic of a cells population abundantly present in the embryonic heart (Figure 11). Some of these cells remain undifferentiated even after the complete formation of the heart but their number decreases gradually. In the adult heart, Isl1 ${ }^{+}$cardioblasts are present in groups in both atria and ventricles as single cells. They express specific markers of early cardiac tissue, such as Nkx2.5 and GATA4, but do not express transcription factors typical of mature cardiomyocytes and are also negative for Sca-1 and c- 
kit (Laugwitz et al. 2005). Is $11^{+}$cardioblasts spontaneously differentiate into cardiomyocytes and express cardiac proteins in the presence of mature cardiomyocytes independently of their fusion with them. Isl1 cells can also give rise to smooth muscle and endothelial cells (Laugwitz et al. 2008).

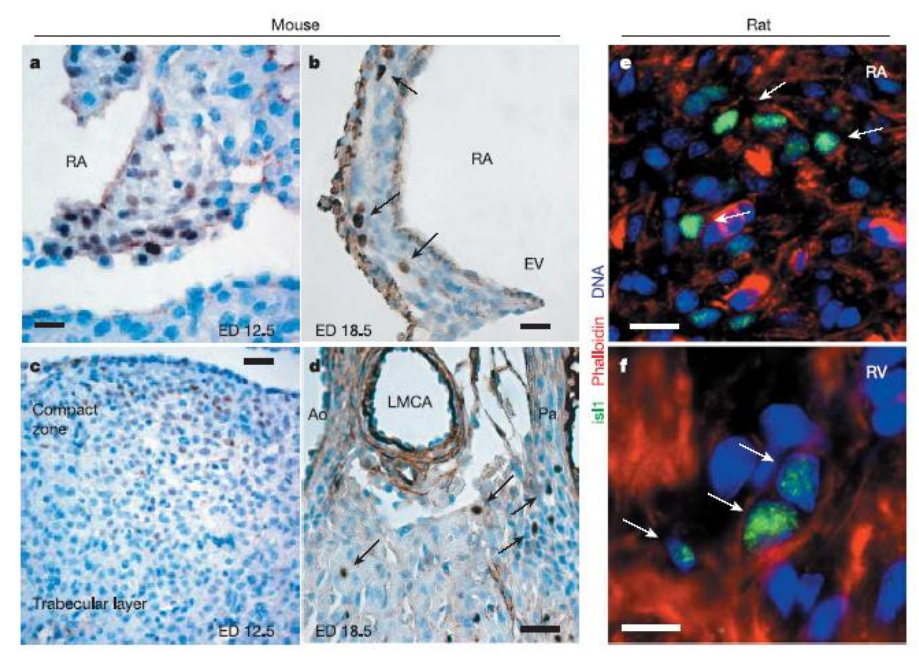

Figure 11. Isl1 ${ }^{+}$progenitors in the late embryonic and postnatal heart (Laugwitz et al. 2005).

\subsubsection{Mesoangioblasts}

A possible alternative source of precursors is represented by mesoangioblasts (Mabs), vessel-associated progenitor cells that can differentiate into all cell types of the mesoderm, so also into cardiac tissue but with a low efficiency 
(Minasi et al. 2002; De Angelis et al. 1999; Jackson et al. 1999; Cossu and Bianco 2003). Mesoangioblasts and hemangioblasts derive from a common ancestor, the primitive angioblasts, located in the region aorta-gonadmesonephros (AGM). Mesoangioblasts are able to repair the damaged heart tissue by different mechanisms. In 2005, Galli et al. have shown that intraarterial injection of mesoangioblasts isolated from the dorsal aorta of embryos at 9.5 days improves cardiac function in rats subjected to myocardial infarction. It has been hypothesized that this benefit depends on the formation of new blood vessels around the infarcted area, on the greater survival of the heart tissue and, to a lesser extent, on the formation of new cardiomyocytes. One of the main mechanisms is the release by the transplanted cells of growth factors and chemokines that promote the formation of new blood vessels and, consequently, reduce the death of the surviving cardiomyocytes. Among these, VEGFB (Vascular Endothelial Growth Factor B) is known to be a growth factor that promotes angiogenesis and maturation of the neovessels.

The mesoangioblasts also produce other growth factors that promote the cardiomyocytes survival independently of the formation of new blood vessels, including bFGF, HGF (Hepatocyte Growth Factor) and IGF1 (Insulin-like Growth Factor 1) (Figure 12). Differentiation of mesoangioblasts into cardiomyocytes is, however, a very rare event (Galli et al. 2005). 


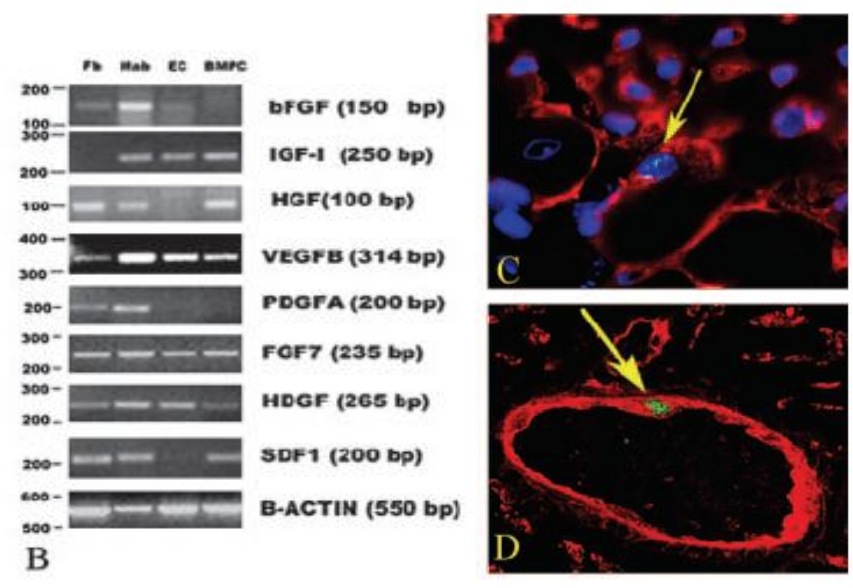

Figure 12. Growth factors producedby mesoangioblasts (Galli et al. 2005).

\subsubsection{Cardiac mesoangioblasts}

Cardiac mesoangioblasts have been isolated from the vessels of ventricle, atrium and aorta taken from the heart of adult mice. Cardiac mesoangioblasts have the same phenotypic characteristics of embryonic mesoangioblasts but express genes necessary for cardiac differentiation, such as Nkx2.5, GATA4 and Connexin43 (Cx43). They do not express, however, muscle markers and are unable to differentiate into skeletal muscle. Unlike embryonic mesoangioblasts, cardiac mesoangioblasts are able to produce osteoblasts or adipocytes but they maintain the ability to differentiate into smooth muscle. Their vascular origin is demonstrated by the fact that they express some of the 
early endothelial markers, including CD31, CD34, NG2 and alkaline phosphatase (AP). Cardiac mesoangioblasts isolated from the ventricle differentiate spontaneously in vitro in functional cardiomyocytes with high efficiency (Figure 13). Differently, cells isolated from the aorta show a high differentiation potential while cells of atrial origin are not able to spontaneously differentiate into cardiomyocytes and with low efficiency, although cocultured with fetal rat cardiomyocytes. Cardiac mesoangioblasts are also able to reach and colonize the damaged heart tissue in a model of myocardial infarction (Galvez et al. 2008).
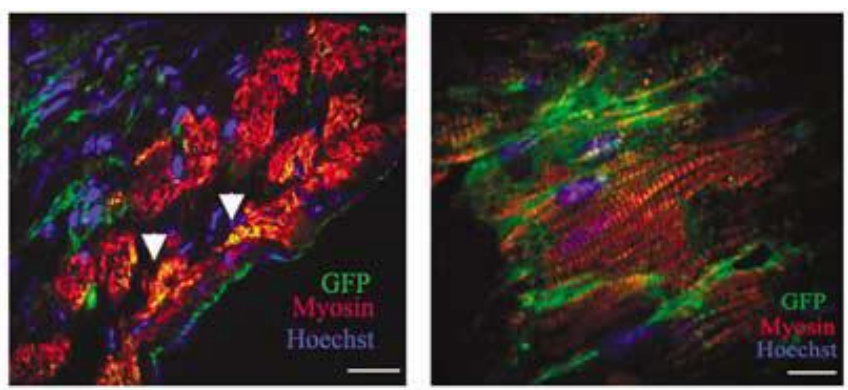

Figure 13. Differentiation of cardiac mesoangioblasts (Galvez et al. 2008). 


\subsubsection{Mesenchymal stem cells}

Mesenchymal stem cells (MSC) are mainly found in the bone marrow stroma and in adipose tissue, are multipotent, can be easily amplified in culture and differentiate efficiently into different cell types including adipocytes, chondrocytes, osteoblasts and endothelial cells (Pittenger et al. 1999). Despite the fact that they differentiate into contracting cardiomyocytes with low efficiency, MSC administration leads to a significant functional improvement and to a lower mortality rate (Silva et al. 2005). However, the ability of MSCs to transdifferentiate into cardiomyocytes is highly controversial (Rose et al. 2008) and their beneficial effect is thought to derive mainly from their influence on neovascularization of the ischemic tissue and their protection of resident cells (Gnecchi et al. 2008). This property, together with their low immunogenicity (Aggarwal et al. 2005), make MSCs an efficient cellular vehicle for delivering therapeutic substances to the myocardial lesion (Boudoulas et al. 2009), promoting their use in allogeneic recipients as well. 


\subsubsection{Skeletal myoblast cells}

Skeletal myoblasts, or satellite cells, are the endogenous stem cell population that efficiently maintains homeostasis in skeletal muscle (Buckingham et al. 2008). They are easy to isolate and propagate in vitro. The similarity between skeletal and cardiac muscle cells suggests that satellite cells should be able to switch towards a cardiomyocytes fate once inside the ventricular tissue. However, even if the administration of satellite cells brings the formation of contracting cells, these largely fail to form intercalated disks and appropriate gap junctions with resident cardiomyocytes (Reinecke et al. 2002), often causing serious arrhythmias (Leobon et al. 2003).

\subsubsection{Bone marrow-derived progenitor cells}

Bone marrow-derived progenitor cells (BMPCs) are a heterogeneous mixture that comprises endothelial progenitor cells, mononuclear bone marrow cells and $\mathrm{CD} 34^{+}$cells. BMPCs have been administered to patients affected by acute myocardial infarction or chronic ischemic heart failure with positive effects on cardiac function and documented safety of this therapeutic approach (MartinRendon et al. 2008). These cells constitute an appealing source of cardiac 
precursors because they can be easily collected from bone marrow aspirates or from the peripheral blood. However, BMPCs plasticity and their ability to acquire the cardiomyocytes lineage after infarction are still controversial (Hosoda et al. 2010).

\subsubsection{Endothelial and epicardial progenitor cells}

Finally, both endothelial (Zeisberg et al. 2007) and epicardial (van Tuyn et al. 2007) cells become activated after injury and give rise to cardiac, vascular and myofibroblast/smooth muscle cells resuming their capacity during development. In particular, during heart development, cells from the proepicardial organ spread over the naked heart tube to form the epicardium. From here, epicardium-derived cells (EPDCs) migrate into the myocardium. The epicardium is the principal source of precursor cells for coronary vasculogenesis (Perez-Pomares et al. 2006). More recently, the epicardium has been shown to contribute $\sim 4 \%$ of the cardiomyocytes of the developed heart (Cai et al. 2008). Furthermore, EPDCs proved to be indispensable for the formation of the ventricular compact zone and myocardial maturation, by largely unknown mechanisms. EPDCs also contribute to the development of ventricular myocardiumand can stimulate neonatal cardiomyocytes 
proliferation, a phenomenon that was described earlier for fetal cardiomyocytes (Weeke-Klimp et al 2010). They express some genes typical of cardiomyocytes, such as CX43 and Mef2a and are also characterized by the specific markers of epicardium, such as Tbx18, epicardin (TCF21) and WT-1 (Smart et al. 2009). These evidences suggest that the epicardium can be a possible site of origin for resident stem or progenitor cell populations in the mouse and in the human (Figure 14) (Zhou1 et al. 2008; Smart et al. 2009; Smart et al. 2011; Zhou2 et al. 2008).
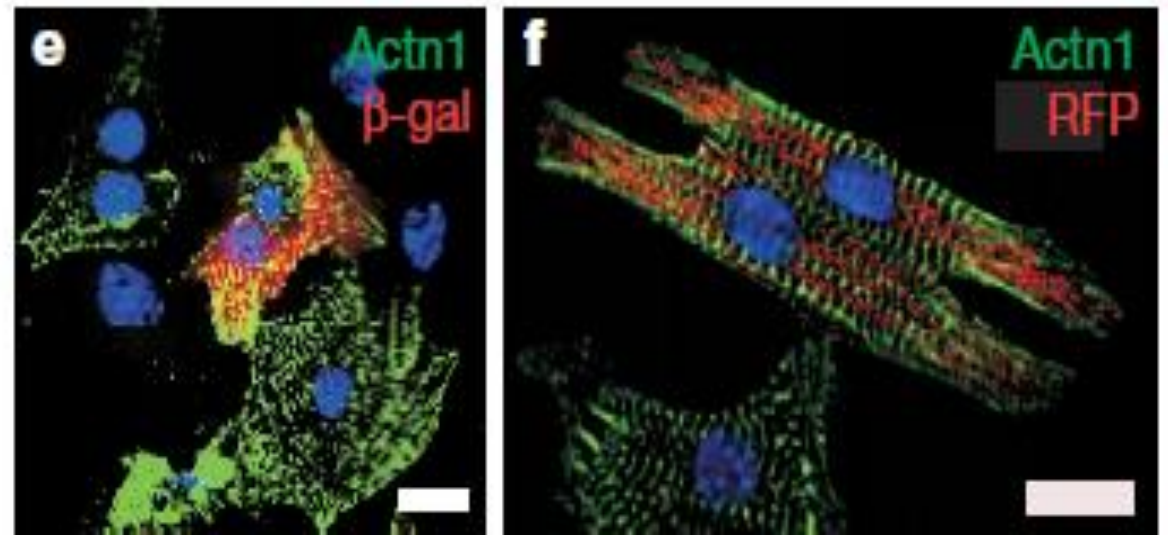

Figure 14. EPDCs-derived cells differentiate into cardiomyocytes (Zhou1 et al. 2008). 
1.7. Cardiac stem cells available in large animal models

After having described the different kind of cardiogenic population cells known so far in the heart or in other organs able to generate cardiomyocytes, we now describe which cells are available in the most common large animal models, such as dog, sheep and pig (Figure 15).

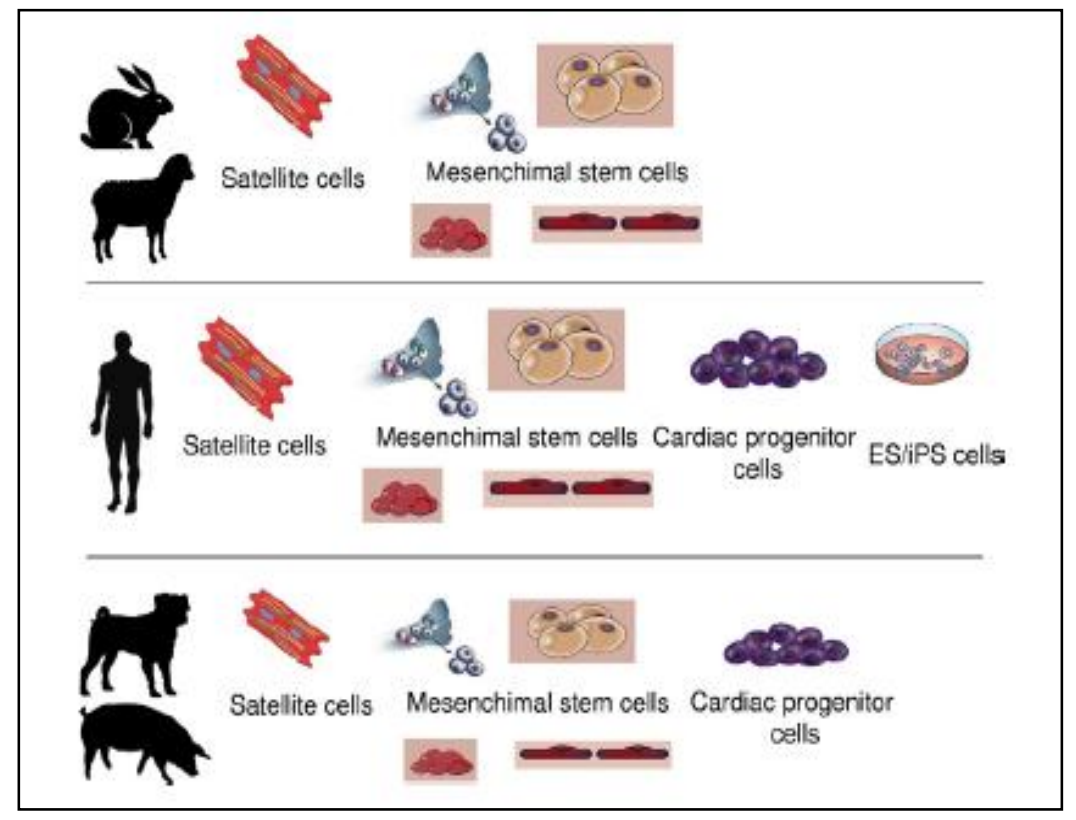

Figure 15. Cardiac stem cells available in large animal models.

Dog cardiac stem cells are available from different sources. Furthermore, canine skeletal muscle satellite cells were one of the first cell types isolated and tested for their capacity to regenerate damaged myocardial tissue providing proof of principle studies on the safety and efficacy of this method (Yoon et 
al. 1995). One of the most investigated cell type is the bone marrow-derived MSC that has the important advantage of eliciting a very mild immune response and can therefore be used in heterologous transplants with no need of immunosuppressive treatments (Silva et al. 2005). Dog MSCs can also undergo cardiomyogenic specification by ex vivo pre-treatment with specific growth factors, thus improving their regenerative properties (Bartunek et al. 2007). These cells have positive effects when administered after both an acute or chronic myocardial ischemia (Silva et al. 2005; Vulliet et al. 2004). Very recent data demonstrate that it is possible to derive dog endothelial progenitor cells and, thanks to the anatomical similarities described above, it was possible to demonstrate that these cells can also be administered effectively following subendocardial injections, a clinically more practical route of administration (Mitchell et al. 2010). The dog heart also possesses an endogenous cardiac stem cell pool characterized by undifferentiated cells that are self-renewing, clonogenic and multipotent (Linke et al. 2005). As described for the corresponding human cells (Beltrami et al. 2003) canine CSCs express c-kit, MDR1, and Sca-1-like antigens suggesting that results obtained in the dog are likely to be relevant to man. Dog CSCs can also form three-dimensional cell aggregates, so called cardiospheres, whose regenerative properties are currently under investigation (Bartosh et al. 2008). Sheep mesenchymal stem cells can be easily derived as in other large animal models (Weir et al. 2008). In this species 
the perivascular STRO-3 positive mesenchymal precursor cells (MPCs), a small fraction of mesenchymal stem cells that demonstrate an extensive capacity for proliferation and differentiation, have also been identified and tested for their regenerative properties (Hamamoto et al. 2009).

Sheep is often used to study the possibility to use MSC for cardiac valve regeneration in association with bioabsorbable valved patches (Kalfa et al. 2010; Sutherland et al. 2005). Bone marrow mononuclear cells (BMMC) have been used to create in vitro tissue-engineered heart valves based on a decellularized porcine scaffold then tested in autologous transplantats (Vincentelli et al. 2007). Endothelial progenitor cells (EPCs) have also been used as a cell source for the creation of tissue-engineered heart valves in sheep (Sales et al. 2010). Skeletal myoblast can be derived and propagated in vitro in sheep as described in other species and large areas of grafted cells can be found within the myocardial lesion, however the cells maintain the histological features of well-differentiated skeletal muscle cells (Ghostine et al. 2002).

Pig cardiogenic stem cells are the most studied. In this species all sort of bone marrow-derived stem cells are currently available. These include BM-derived mononuclear cells (BM-MNCs) (Kamihata et al. 2001; Bhakta et al. 2006; Makela et al. 2007), peripheral blood mononuclear cells (PB-MNCs) (Kamihata et al. 2002; Doyle et al. 2008) and BM-derived mesenchymal stem cells (Pak et al. 2003). Bone marrow-derived MSC have been magnetically 
labeled in order to develop non-invasive methods for studying the engraftment based on magnetic resonance imaging (MRI) (Kraitchman et al. 2003; He et al. 2007). Pig MSC were used also to explore new delivery methods like a patch of a fibrin matrix seeded with autologous cells (Liu et al. 2004). As it was observed in other species, pig MSCs can be prepared from an allogeneic donor without being rejected, confirming that these cells have a major practical advantage for their widespread application in a clinical setting (Amado et al. 2005) and are also being tested for proving the safety of an "offthe-shelf' cellular cardiomyoplasty strategy (Poh et al. 2007). In addition, direct intramyocardial injection of MSCs results in successful engraftment and differentiation into cardiomyocytes and endothelial cells and preserves left ventricular function in acute (Makkar et al. 2005) and chronic myocardial lesions (Schuleri et al. 2009). Cardiogenic stem cells have been derived from pig adipose tissue (ADSCs) and can engraft in the infracted region four weeks after transcatheter intracoronary cell transplantation improving cardiac function and perfusion via angiogenesis with an efficiency comparable to that of bone marrow-derived stem cells (Valina et al. 2007). Pig amniotic fluidderived mesenchymal cells (AFC) are also available. However, when auto transplanted in a porcine model of acute myocardial infarction, AFC are able to transdifferentiate to cells of vascular cell lineages but not to cardiomyocytes (Sartore et al. 2005). Resident cardiac stem cells can be derived from pig 
endomyocardial specimens. When pig CSCs are grown in primary culture they form cardiospheres that can be plated to obtain cardiosphere-derived cells (CDCs). CDCs are cardiogenic in vitro as indicated by spontaneous intracellular calcium transients and action potentials as well as fast, inward sodium currents, however, cardiospheres and CDCs do not spontaneously contract (Smith et al. 2007). Satellite cells and many different kind of mesenchymal cell types are available in every large animal model species but cardiac progenitor cells have been derived only in dog and pig while in human cardiac stem cells can be either endogenous or derive from outside the heart itself like satellite cells, different kind of mesenchymal stem cells, or embryonic/iP stem cells. Recently, an exhaustive study reported the isolation of a c-kit ${ }^{+} / \mathrm{CD} 45^{-}$ cardiogenic cell population from weanling pigs (Figure 16)(Ellison et al. 2011), demonstrating a robust regenerative effect of these cells that are most likely involved in the myocardium hyperplastic growth and maturation to adulthood, consistent with data previously shown in neonatal mice (Zaruba et al. 2010). 
c-kit ${ }^{\text {pos }}$ CD45 ${ }^{\text {neg }}$ Cardiac Cells

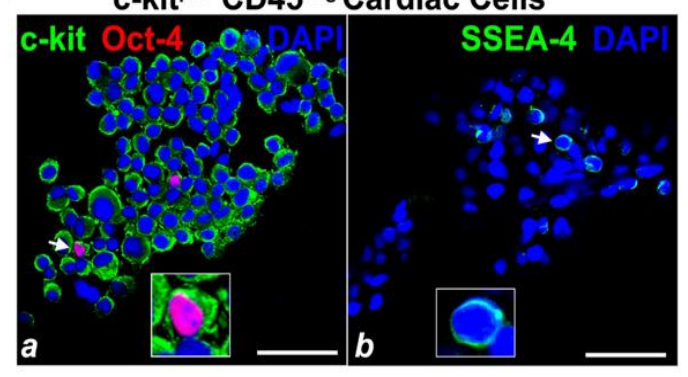

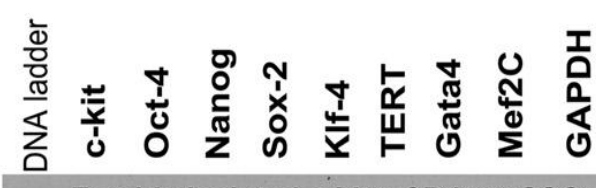

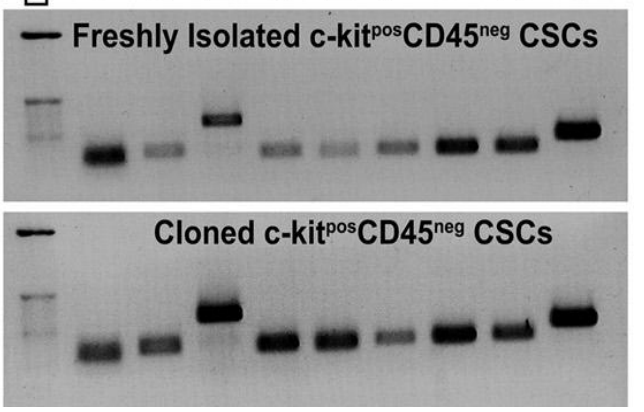

Figure 16. Phenotype of Porcine c-kitposCD45neg Cardiac Stem/Progenitor cells. 
1.8. Which animal for which pathology?

Large animal models are a heterogeneous group and, as such, there is no single perfect animal model. The more common large animal models used in cardiac disease are dog, pig and sheep.

Dogs are becoming an increasingly popular model due to their behavior and ease of handling. Research on dogs built the foundation on which current reperfusion treatment guidelines for acute coronary syndromes were developed and provided proof of concept for thrombolytic therapy. Physiological similarities with humans extend to the endocrine system enabling the study of the cardioprotective effect of drugs modulating the reninangiotensin pathway (Jugdutt et al. 2004). However relation between heart size and body weight in the dog compared to human is almost twice and, on the other hand, dog heart has a collateral coronary circulation approximately four times more extended than that of man, making it difficult to obtain a consistent degree of myocardial injury following experimental ischemia and to reliably extrapolate to human the post-infarction course observed in dogs (White et al. 1986).

Pig seems to differ from man in its predisposition for refractory arrhythmogenesis, providing an altered response to myocardial infarction, 
although methods are available to reduce the impact of this issue (Mukherjee et al. 2003).

When it comes to heart vascularisation, detailed anatomical studies show that the pig is by far the best model. In fact, not only the coronary anatomy but even the poor subendocardial to epicardial collateral network of the swine heart are very similar to that of humans (Weaver et al. 1986). Minor differences have only been described in the septal arteries: the anterior ones provide most of the irroration in man, whereas in the porcine heart, anterior and posterior arteries share the septal ventricular vascularisation almost equally (Bertho et al. 1964). Such extensive similarities allowed us to perform studies that evaluated the re-establishment of stable collateral networks and improved myocardial perfusion in response to the administration of angiogenic growth factors (Lu et al. 2007).

When postinfarction congestive heart failure is to be studied, the sheep is a better model because lack of collateral blood flow to the infarcted area, maintenance of normal blood flow to uninfarcted areas, and the moderate size of the infarcted myocardium allow us to faithfully reproduce the three major clinical causes of this pathology (Mukherjee et al. 2003). This has greatly contributed to the understanding of differing outcomes dependent on specific locations of MI creation (Gorman et al. 1998). Limitations of working with sheep, being ruminants, derive from their gastrointestinal anatomy and 
thoracic contours that are substantially different from those of monogastric species. This can make certain imaging approaches difficult, specifically ultrasonic imaging that requires an invasive approach as opposed to transthoracic imaging applicable to other models. 
1.9. Murine models for cardiac disease

Cardiovascular disease is controlled both genetically and environmentally. Much of our insight into the molecular and cellular basis of cardiovascular biology comes from small animal models, particularly mice. However, significant differences exist with regard to several cardiac characteristics when mice are compared with humans (Table 1) (Gandolfi et al. 2011; Dixon et al. 2009).

Species

Heart weight

(gr)

Human

Mouse

\section{$360-480$}

$0.14-0.15$
Heart

(rate/min)
Systolic pressure

(mmHg)

\begin{tabular}{|c|cc|}
\hline $360-480$ & $60-90$ & $60-120$ \\
$0.14-0.15$ & $500-600$ & $80-160$ \\
\hline
\end{tabular}

Table 1. Comparison of indicative anatomy and physiology data between the human and the mouse (Gandolfi et al. 2011) (Appendix a).

An important parameter is heart rate, with an adult mouse heart beating $500-$ 600 times per minute, compared with the 60-100 times typical of the human. Apart from size, human and murine hearts differ in coronary architecture, the variations of which are much bigger in humans compared with mice. As a 
consequence, whereas the size and location of the ischemic area are fairly constant in the mouse, a much larger variation exists in the human (Blankesteijn et al. 2001). It is also important to remember the basic differences in cardiovascular physiology between mice and humans. Although it is clear that the basic organizational, developmental, and signaling pathways are conserved, and much can be learned from the mouse models, the subtleties of the different proteomes and the way in which the different components interact and differ between mice and humans are critical, particularly when therapeutic approaches are considered. Important differences continue at the molecular level: humans have a high level of myosin heavy chain isoform, whereas mice have a high level of the myosin heavy chain isoform compared with the total myofibrillar myosin protein in the ventricles (Doevendans et al. 1998; Swynghedauw et al. 1986). Despite these differences, significant data have accumulated in which the contractile apparatus, including myosin, has been modified, resulting in hypertrophy or dilation followed by failure. These kinds of important physiological differences can be found in many of the basic parameters underlying cardiac output (Stull et al. 2002), cardiac electrophysiology (Baker et al. 2000) and calcium flux (Bers et al. 2000). Although these concerns do not negate data gathered with the use of the murine models, they underscore the fact that the murine data should invariably be treated with caution as they are applied to human disease 
(Yutzey et al. 2007). Furthermore, the use of the mouse as an experimental system for cardiovascular research depends on the individual investigator's ability to manipulate the mice surgically (Figure 17). Many mouse models require microsurgical techniques, which hitherto could not be performed without practical training.

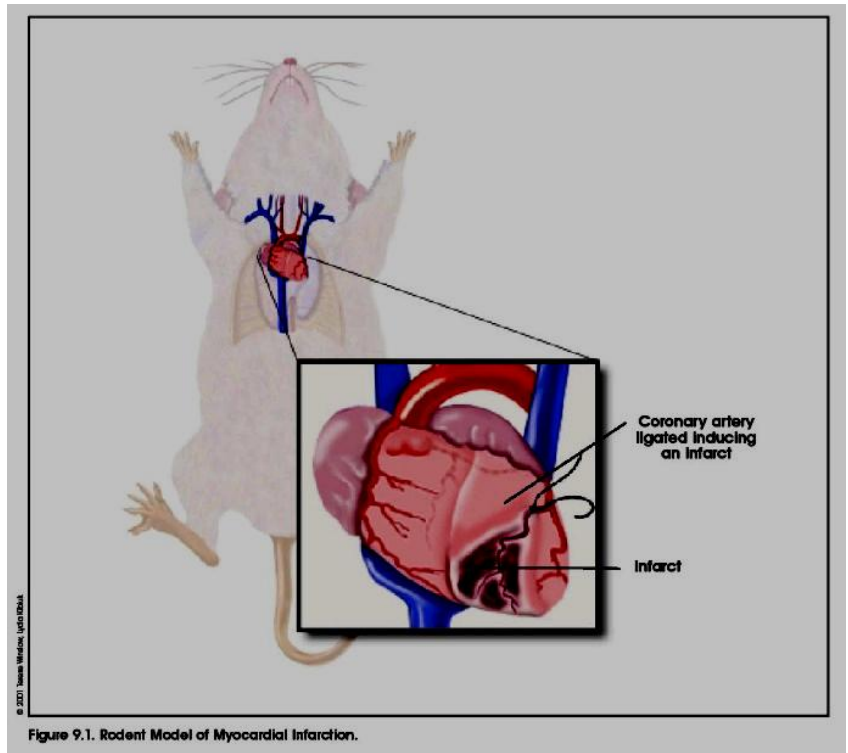

Figure 17. Cardiac mouse microsurgery (Sussman et al. 2001). 
Consequently, there remains a need for new animal models that closely represent human disease. Extrapolation of murine systems, particularly after induction of cardiovascular stress, has some obvious limits that can be crucial the closer it gets to a clinical application. Therefore, it is generally acknowledged that large animal models, which more closely approximate human physiology, function and anatomy, are essential to develop the discoveries from murine models into stem cell research and their translation into new clinical treatments (Dixon et al. 2009). 
1.10. Porcine models for heart disease

To improve human health, scientific discoveries and technologies must be translated into practical applications. Such advances typically begin with basic research and then progress to the clinical level. Inherent in the development of these technologies is the role of preclinical testing using animal models. Although no animal model can fully replicate the complexity of human pathological conditions, animal models are the key for the evaluation of mechanisms of disease and testing of diagnostic technologies and interventions. Large animal models that approximate human physiology, function, and anatomy, are essential to develop discoveries from murine models into clinical therapies and interventions. Following the results obtained so far and the prospect of a future therapy in humans, it is considered necessary to pursue these studies in an animal model intermediate between the mouse and human: for this purpose it has been chosen the pig. The pig, in fact, has been widely used as a model in cardiovascular research (Guiney et al. 1965; Bustad and McClellan 1966; Douglas et al. 1972; Hughes et al. 1986) and, over the past decade, swine have been increasingly used in studies of chronic ischemia because of their numerous similarities to humans (Table 2). 


\begin{tabular}{c|ccc|} 
Species & $\begin{array}{c}\text { Heart weight } \\
(\mathbf{g r})\end{array}$ & $\begin{array}{c}\text { Heart } \\
\text { (rate/min) }\end{array}$ & $\begin{array}{c}\text { Systolic pressure } \\
(\mathbf{m m H g})\end{array}$ \\
\hline Pig & $400-500$ & $65-75$ & $70-130$ \\
Human & $360-480$ & $60-90$ & $60-120$ \\
Mouse & $0.14-0.15$ & $500-600$ & $80-160$
\end{tabular}

Table 2. Comparison of indicative anatomy and physiology data between the pig, the human and the mouse (Gandolfi et al. 2011) (Appendix a).

The most widely used porcine model of chronic ischemia has been the ameroid constrictor (Elzinga et al. 1969; Inou et al. 1980; O’Konski et al. 1987; Roth et al. 1987), which has been utilized in preclinical studies of numerous proangiogenic therapies. When the device is implanted around an artery, the constrictor absorbs water and swells, compressing the artery and leading to a progressive coronary stenosis with late occlusion with consequent myocardial ischemia and ventricular dysfunction.

On the other hand, heart failure could be produced only by using acute coronary occlusion caused by the ligation of the descending coronary artery. In particular, in the ischemia/reperfusion model, the coronary artery occlusion is followed by the reperfusion of the infarcted area after $\sim 30-40$ minutes. Reperfusion offers two important advantages. It increases the success rate of 
cell therapy in limiting the damage to heart tissue and it also allows to reach more directly the infarcted area through the intra-coronary artery injection of cardiac stem cells. Two different ways of cell injection can be used.

Intra-arterial (IA) injection represents an experimental avenue for minimally invasive delivery of stem cells to the injured heart but the achievement of the injected cells to the ischemic area depends on the ability of these cells to migrate from blood vessels to the damaged myocardium.

The intra-ventricular (IV) injection consists of the introduction of materials for diffusion throughout the ventricular and subarachnoid space by means of ventricular puncture. IV, instead, allows the injection of the cardiogenic cells directly into the wall surrounding the infarcted area (Figure 18).

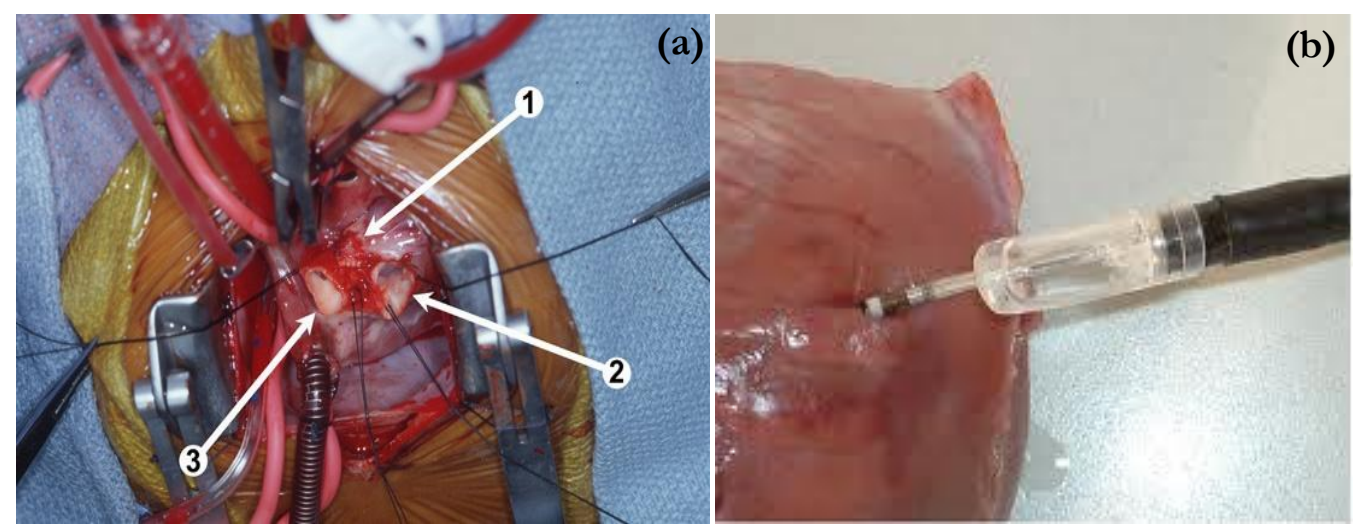

Figure 18. Surgical ligation of the descending coronary artery (a); intraventricular injection of cardiogenic cells (b) (courtesy of Dott. F. Acocella). 
According to these evidences, recent several studies clearly established that the best replacement for the lost myocardium after myocardial infarction is functional autologous myocardial tissue. However, its derivation from autologous stem cells is too slow and inefficient to be of real benefit in a clinical setting (Torella et al. 2007). Therefore, it has recently been proposed that a more promising approach to the regenerative medicine is to stimulate the activation of the resident stem cell population (Nadal-Ginard et al. 2006; Rossi et al. 2008). 


\section{Aim of the research}

The recent identification of different classes of cardiac progenitor cells suggests that the heart, classically considered a terminally differentiated, postmitotic organ, may contain a stem cell compartment, responsible for both tissue turn-over and regeneration, which follows acute or chronic damage to the cardiac tissue (Bergamann et al. 2006; Hsieh et al. 2007).

Several groups have already reported the isolation of different types of cardiac stem-like cells based on distinct cell surface markers, such as c-kit, Sca-1 and Isl1 (Beltrami et al. 2003; Rota et al. 2008; Laugwitz et al. 2008; Matsuura et al. 2004; Oh et al. 2003), but the experiments carried out until now were predominantly performed on mice and human. This restricts significantly the possibility to apply the results obtained in preclinical studies that cannot be performed using the human as a model and, at the same time, are limited by the evident differences between mouse and humans, such as their size, mice heart rate and their general anatomy. Therefore, large animal models, which more closely approximate human physiology, function, and anatomy, are essential to develop the discoveries from murine models into clinical therapies and interventions.

However, cardiogenic cells were already found in large animal models. Dog cardiogenic cells are available from different sources, such as skeletal muscle 
satellite cells (Yoon et al. 1995), bone marrow-derived cells (Silva et al. 2005) or cardiac stem cells (Bartosh et al. 2008). Sheep instead contained mesenchymal stem cells (Kalfa et al. 2010), bone marrow-derived cells (Vincentelli et al. 2007), endothelial progenitor cells (Sales et al. 2010) and skeletal muscle satellite cells (Ghostine et al. 2002). Pig was characterized for the presence of cardiogenic cells, such as bone marrow-derived cells (Kamihata et al. 2001; Bhakta et al. 2006; Makela et al. 2007; Doyle et al. 2008; Pak et al. 2003; He et al. 2007; Liu et al. 2004), adipose tissue cells (Valina et al. 2007), amniotic fluid-derived mesenchymal cells (Sartore et al. 2005) and resident cardiac stem cells, recently described in weanling pigs (Torella et al. 2006).

In this context, it seems to be accepted in the literature that the anatomy of the pig heart is almost identical to that of man, respect to the dog and the sheep (Lumb et al. 1966; Douglas et al. 1972; Hughes et al. 1986; Cooper et al. 1991; White and Wallwork 1993).

According with the recent discoveries that proposed as a more promising approach to the regenerative medicine the activation of the resident stem cell population, the aim of this study was to see whether resident cardiac stem cells also existed in adult swine, in order to verify whether adult pig could be a suitable model for a therapeutic approach. 
We also wanted to deepen the characterization of these cells in order to better understand the molecular mechanisms involved in the tissue regeneration and in the damaged myocardium reparation processes.

In particular, in this thesis we describe the isolation of a cell population derived from aorta, ventricle and atrium of adult healthy pig, thasat we arbitrarily defined Pig Adult Cardiac Progenitors (PACPs).

Cells were analyzed for their expansion ability and for the expression of surface markers by flow cytometry. Molecular characterization was performed using primers designed for pluripotency, mesenchymal and cardiac related genes. Furthermore, the ability of PACPs to differentiate into cardiomyocytes and into other mesodermal cell lines, such as smooth muscle, were assessed using specific cardiac antibodies, when exposed to the appropriate inducing media. The PACPs capacity to generate cardiomyocytes was confirmed by fusion event analysis after coculture with fetal rat cardiomyocytes.

Thus, all these experiments were carried out in order to evaluate the potential future application for human cell therapy of PACPs that may represent an interesting tool for preclinical and translational studies of stem cell-based cardiovascular therapy. 


\section{Materials and methods}

\subsection{Isolation and culture of Pig Adult Cardiac Progenitors}

Adult healthy pig hearts were collect at the slaughterhouse and then transported to the laboratory in a saline solution $(0.9 \% \mathrm{NaCl})$ in controlled temperature conditions. Once they arrived in the laboratory, hearts were rinsed in saline solution to remove blood residues. Then, aorta, atrium and ventricle were cut in small pieces. Each piece was rinsed in PBS (SigmaAldrich ${ }^{\mathrm{TM}}$, Italy) with $\mathrm{Ca}^{2+} / \mathrm{Mg}^{2+}$ and sharply dissected into 1-2 mm diameter fragments. They were transferred to $35 \mathrm{~mm}$ Petri dishes (Sarstedt, Germany) pre-coated with $0.1 \%$ porcine gelatin, in the presence of $500 \mu$ l Dulbecco's Modified Eagle’s Medium high glucose (DMEM, Gibco, Italy) supplemented with 10\% fetal bovine serum (FBS, Gibco, Italy), 1\% glutamine and 1\% antibiotics (Sigma-Aldrich ${ }^{\mathrm{TM}}$, Italy) (complete medium) (Table 3). Heart fragments were cultured for 10 days at $37^{\circ} \mathrm{C}$. After the initial outgrowth of fibroblast-like cells, small and round cells appeared in suspension, given their lower adhesion ability respect the other cells present in the culture (predominantly fibroblasts). This cell population was easily collected by gently pipetting the original culture and counted by limited dilution on a $0,1 \%$ gelatin (Table 4) pre-coated $35 \mathrm{~mm}$ Petri dish (Sarstedt, Germany). After 3 days, 
PACPs were washed 2 times in PBS, incubated for 5 minutes with $1 \mathrm{ml}$ Trypsin (Sigma-Aldrich ${ }^{\mathrm{TM}}$, Italy) and centrifuged at $1250 \mathrm{rpm}$ for 5 minutes. The supernatant obtained was removed and the pellet was resuspended in the specific volume to obtain the right density. PACPs were expanded in vitro in flask (T25, Nunc) for further characterization. 


\begin{tabular}{|c|c|}
\hline Components & Quantity \\
\hline Dulbecco's Modified Eagle's Medium & $88 \mathrm{ml}$ \\
High glucose (DMEM, Gibco, Italy) & $10 \mathrm{ml}(10 \%)$ \\
\hline Fetal Bovine Serum (FBS, Gibco, & \\
Italy) & $1 \mathrm{ml}(1 \%)$ \\
\hline L-glutamine $200 \mathrm{mM}($ Sigma- & $1 \mathrm{ml}(1 \%)$ \\
\hline Aldrich ${ }^{\text {TM }}$, Italy) & \\
\hline Penicillin/Streptomycin $10 \mathrm{mg} / \mathrm{ml}$ & $100 \mathrm{ml}$ \\
\hline Sigma-Aldrich ${ }^{\text {TM }}$, Italy) & \\
\hline
\end{tabular}

Table 3. Complete medium used for PACPs in vitro culture.

\begin{tabular}{|c|c|}
\hline Components & Quantity \\
\hline Porcine gelatin & $0.1 \mathrm{~g}$ \\
\hline $\begin{array}{c}\text { Cell Culture Water (Sigma-Aldrich } \\
\text { Italy) }\end{array}$ & Up to $100 \mathrm{ml}$ \\
\hline
\end{tabular}

Table 4. Sterile solution of $0.1 \%$ porcine gelatin. 
3.2. Analysis of Pig Adult Cardiac Progenitor proliferation ability

PACPs isolated from aorta, atrium and ventricle respectively were plated in 4 well dishes (Nunc, USA) in complete medium at a density of $5 \times 10^{4} \mathrm{cells} / \mathrm{cm}^{2}$. Each population derived from aorta, atrium and ventricle was plated with 4 replicates. Cells were then counted every 3 days for 21 days using Kova Glasstic ${ }^{\circledR}$ slide (Hycor, UK). During the analysis, PACPs were washed with PBS, trypsinized and then $10 \mu \mathrm{l}$ were used for the counting. Cells were stained with $0.8 \mathrm{mM}$ Trypan Blue (Sigma, Italy) at room temperature for 30 minutes to discriminate living cells from dead ones that stained blue due to trypan blue uptake. The total number of living cells was determined by the following proportion:

$\left(\mathrm{N}^{\circ}\right.$ of cells counted $/ 10$ fields) $* 90$ (constant) $* 100$ (dilution factor) 
3.3. Karyotype of Pig Adult Cardiac Progenitors

Karyotype analysis was carried out on cells undergoing active proliferation. In particular, $2 \times 10^{6}$ cells were plated in 4 well dishes in complete medium and allowed to reach $80 \%$ confluence. PACPs were washed with PBS and incubated with $10 \mu \mathrm{g} / \mathrm{ml}$ colcemid (Gibco, Italy), to arrest cells in metaphase, for 40 minutes in a humidified incubator $\left(5 \% \mathrm{CO}_{2}, 37^{\circ} \mathrm{C}\right)$ and then trypsinized. Mitotic PACPs were centrifuged at $1000 \mathrm{rpm}$ for 5 minutes.

The pelleted cells were resuspended in $5 \mathrm{ml} 0.075 \mathrm{M}$ hypotonic buffer $(0.04 \mathrm{M}$ $\mathrm{KCl}$ and $0.025 \mathrm{M} \mathrm{NaCl}$ ) and incubated for 20 minutes at room temperature. PACPs were pelleted again at $1000 \mathrm{rpm}$ for 5 minutes. The supernatant fraction was carefully aspirated and discarded. Cells were resuspended in $5 \mathrm{ml}$ methanol/glacial acetic acid (3:1) fixative solution and incubated for 20 minutes. PACPs were pelleted by centrifugation at $2000 \mathrm{rpm}$ for 2 minutes and resuspended in $100 \mu \mathrm{l}$ fixative solution. Fixed cells were stored at $4^{\circ} \mathrm{C}$; otherwise cells were dropped on wet slides and air-dried for the following procedure.

Giemsa staining was carried out using the KaryoMAX®) kit (Giemsa, Gibco, Italy). Mitotic spreads were stained with Giemsa 1X staining buffer at room temperature for 20 minutes. Slides were rinsed with Gurr's buffer for 3 times and air-dried at room temperature for 30 minutes. 
Metaphases were fully karyotyped under a Leica HC microscope. Images were then captured with digital camera Leica DC250 and using Leica CW4000 Karyo software. 
3.4. Gene expression profile

\subsubsection{RNA extraction}

Total RNA from PACPs was obtained following the method described by Chomczynski and Sacchi 1987. Cell RNA was isolated during cells lysis for 10 minutes at room temperature with $1 \mathrm{ml}$ Trizol reagent (Invitrogen, Italy), a monophasic denaturing solution that maintains RNA integrity during the lysis process. Samples were left at room temperature for 5 minutes, to maximize the solution denaturing power and its ability to inhibit cellular RNases and disaggregate nucleoprotein complex, favoring the release of free RNA. Two hundred $\mu \mathrm{l}$ chloroform ( $200 \mu \mathrm{l}$ each $\mathrm{ml}$ of Trizol) were added to the sample, shaking the tubes for 15 seconds and allowing them to rest at $4^{\circ} \mathrm{C}$ for 5 minutes. Cells were centrifuged at $14000 \mathrm{rpm}$ for 15 minutes at $4^{\circ} \mathrm{C}$ to separates the solution into an organic phase and an aqueous phase, which contained the RNA. After transferring of the aqueous phase into new tubes, RNA was recovered by precipitation with $500 \mu$ lisopropyl alcohol (ml Trizol/2) and stored at $-20^{\circ} \mathrm{C}$ over-night. After the precipitation, samples were centrifuged at $14000 \mathrm{rpm}$ for 10 minutes at $4^{\circ} \mathrm{C}$ and then the supernatant was discarded without to dry the sample. Cells were resuspended in $1 \mathrm{ml}$ ethanol $70 \%$ and centrifuged at $9000 \mathrm{rpm}$ for 5 minutes at $4^{\circ} \mathrm{C}$. Besides, genomic 
DNA contaminations were removed incubating the samples with DNAase I $\left(1 \mathrm{U} / \mu \mathrm{l}\right.$, Invitrogen, Italy) for 30 minutes at $37^{\circ} \mathrm{C}$. Subsequently, they were incubated for 10 minutes at $55^{\circ} \mathrm{C}$ to inactivate the DNases. The pelleted cells were dried and resuspended in $25 \mu \mathrm{l}$ DiEthylPyroCarbonate (DEPC-treated water) (Invitrogen, Italy), a strong RNases inhibitor, and reverse transcribed. The amount of extracted RNA was assessed by reading the absorbance values using a spectrophotometer (BioRad, SmartSpec ${ }^{\text {TM }}$ 3000) at a wavelength of $260 \mathrm{~nm}$. Spectrophotometer was first calibrated with $100 \mu \mathrm{l}$ DEPC water (the sample blank). Quantification was carried out taking $1 \mu \mathrm{l}$ RNA from each sample and resuspending it in $100 \mu \mathrm{l}$ DEPC water before the reading. The amount of RNA was calculated using the following proportion:

$$
1: 40=\operatorname{Abs}_{260}: \mathrm{X}
$$

The spectrophotometer was also used to calculate the "ratio" (Abs260/Abs280), which indicates the purity of the RNA extracted.

The quality of the extracted RNA was checked after 5\% agarose gel electrophoresis. This method also allows to highlight the possible presence of contaminating genomic DNA. The 5\% agarose gel was composed of $1.7 \mathrm{~g}$ agarose in $95 \mathrm{ml} 1 \mathrm{X}$ TAE (Tris-acetate-EDTA) buffer plus $1 \mu$ l ethidium bromide $\left(0.5 \mu \mathrm{g} / \mu \mathrm{l}\right.$, Sigma-Aldrich ${ }^{\mathrm{TM}}$, Italy), which binds to RNA nucleotide 
bases and makes them visible at UV light. The electrophoretic run was carried out in $1 \mathrm{X}$ TAE buffer at $80 \mathrm{~V}$. Five $\mu \mathrm{l} 50 \mathrm{bp}$ Ladder (Invitrogen, Italy) was used as a marker in the electrophoretic run and samples were added with $5 \mu \mathrm{l}$ Loading Die (0.25\% bromophenol blue, $0.25 \%$ xylene cyanol $+30 \%$ glycerol, Sigma-Aldrich ${ }^{\mathrm{TM}}$, Italy).

\subsection{2. $R N A$ reverse transcription}

Reverse transcription was carried out using the SuperScript ${ }^{\circledR}$ II Reverse Transcriptase kit (Invitrogen, Italy). For each sample, aliquots of $1 \mu \mathrm{g}$ total RNA were reverse transcribed and diluted in $8.5 \mu$ of DEPC water. $1 \mu 110$ $\mathrm{mM}$ dNTPs mix and $1 \mu \mathrm{l}$ oligo (dT) were added to the tubes. Samples were then heated at $65^{\circ} \mathrm{C}$ for 5 minutes to denature any loops on the RNA strand and then resuspended in:

- $4 \mu \mathrm{l}$ First-Strand Buffer 5X

$-1.5 \mu \mathrm{l} \mathrm{MgCl} 250 \mathrm{mM}$

- $2 \mu \mathrm{l}$ DTT $0,1 \mathrm{M}$

- $1 \mu \mathrm{l}$ RNaseOUT (Recombinant Ribonuclease Inhibitor).

They were heated at $42^{\circ} \mathrm{C}$ for 2 minutes and then $1 \mu$ SuperScript ${ }^{\circledR}$ RNase $H$ Reverse Transcriptase was added to the tubes. Samples were incubated at $42^{\circ} \mathrm{C}$ 
for 1 hour. The enzyme was inactivated at $70^{\circ} \mathrm{C}$ for 15 minutes. The cDNA obtained was stored at $-20^{\circ} \mathrm{C}$ until use. Reverse transcription was carried out using a 480 DNA Thermal Cycler (Perkin-Elmer).

\subsubsection{Polymerase Chain Reaction (PCR)}

Polymerase chain reaction (PCR) is a technique used to amplify a single or few copies of a piece of DNA across several orders of magnitude, generating thousands to millions of copies of a particular DNA sequence. The method consists of cycles of repeated heating and cooling of the reaction for DNA melting and enzymatic replication of the DNA. Primers (short DNA fragments) contain sequences complementary to the target region. PCR reactions were carried out using the Taq DNA Polymerase ${ }^{\circledR}$ Recombinant kit (Invitrogen, Italy).

Our PCR mix included:

- $2 \mu \mathrm{l}$ Buffer 10X (200 mM Tris- $\mathrm{HCl} \mathrm{pH}=8.4,500 \mathrm{mM} \mathrm{KCl})$

- $1 \mu \mathrm{l} \mathrm{MgCl}_{2} 50 \mathrm{mM}$

$-1 \mu \mathrm{ldNTPs} \operatorname{mix}(10 \mathrm{mM})$

- $1 \mu \mathrm{l}$ Primer forward $(100 \mathrm{pmol} / \mu \mathrm{l})$

- $1 \mu \mathrm{l}$ Primer reverse $(100 \mathrm{pmol} / \mu \mathrm{l})$ 
- $0.3 \mu \mathrm{l}$ Taq polymerase $(5 \mathrm{U} / \mu \mathrm{l})$

- $1 \mu \mathrm{l}$ cDNA template

- Sterile water until $8.5 \mu 1$

It always involved:

[1] Initialization step

[2] Denaturation step

[3] Annealing step

[4] Elongation step

[5] Final elongation step

[6] Final hold $94^{\circ} \mathrm{C}$ for 5 minutes

$94^{\circ} \mathrm{C}$ for 1 minute

$\mathrm{T}_{\mathrm{a}}=\mathrm{T}_{\mathrm{m}}-4^{\circ} \mathrm{C}$

$72^{\circ} \mathrm{C}$ for 1 minute

$72^{\circ} \mathrm{C}$ for 7 minutes

$4^{\circ} \mathrm{C}$

PCR products were run in 5\% agarose gel. Amplifications were carried out in an automated thermal cycler (iCycler, Bio-Rad, Italy), using the conditions appropriate for each set of primers.

\subsubsection{Pig Adult Progenitor gene expression}

c-kit, LY6G6F (Sca-1), Oct4, Nanog, Sox-2, Gata6, CD31, CD34, CD44, Mesp1, Mesp2, Mef2a, Nkx2.5, ANP, Cx43, Cardiac Actinin, Tbx5, Tbx18, MyoD, Myf5 and $\beta$-actin primers were designed on pig genome sequence available in database bank using the oligo program Primer3 Input. PCR were 
carried out using the conditions specific of each pair of primers (Table 5). Positive controls were always included using genomic DNA or cDNA obtained from the appropriate tissue, depending on the gene (Table 6). Expression of $\beta$-actin was examined as an internal control of the sample quality. To confirm the identity of the RT-PCR fragments, amplification products from each primer pair were separated by gel electrophoresis in $2 \%$ agarose gels, purified using Spin-X centrifuge tube filters (Corning, Italy), sequenced (SEQLAB, Gottingen, Germany) and aligned using Clustal W 1.82 (EMBL-EBI service). 


\begin{tabular}{|c|c|c|c|c|}
\hline GENE & $\begin{array}{c}\text { NCBI } \\
\text { Accession N. }\end{array}$ & Primer sequence & $\begin{array}{c}\text { Annealing } \\
\text { temperature }\end{array}$ & $\begin{array}{l}\text { Fragment } \\
\text { size }\end{array}$ \\
\hline c-kit & NM_001044525.1 & $\begin{array}{l}\text { 5'-TGTGAAGCGCGAGTATCATC-3' } \\
\text { 5'-AGTCTGGCTGTTCTCCCTGA-3' }\end{array}$ & $60^{\circ} \mathrm{C}$ & $238 \mathrm{bp}$ \\
\hline $\begin{array}{c}\text { LY6G6F } \\
\text { (Sca-1) }\end{array}$ & NM_001195349.1 & $\begin{array}{l}\text { 5'-TCTGGAAACCCCTCAGTGAC-3' } \\
\text { 5'-CTCCCACTACCCTCTCCACA-3' }\end{array}$ & $56^{\circ} \mathrm{C}$ & $240 \mathrm{bp}$ \\
\hline Oct-4 & NM_001113060 & $\begin{array}{l}\text { 5'-AGGTGTTCAGCCAAACGACC-3' } \\
\text { 5'-TGATCGTTTGCCCTTCTGGC-3' }\end{array}$ & $50^{\circ} \mathrm{C}$ & $335 \mathrm{bp}$ \\
\hline Nanog & DQ447201.1 & $\begin{array}{l}\text { 5'-ATCCAGCTTGTCCCCAAAG-3' } \\
\text { 5'-ATTTCATTCGCTGGTTCTGG-3' }\end{array}$ & $60^{\circ} \mathrm{C}$ & $438 \mathrm{bp}$ \\
\hline Sox-2 & EU503117.1 & $\begin{array}{l}\text { 5'-GCCCTGCAGTACAACTCCAT-3' } \\
\text { 5'-GCTGATCATGTCCCGTAGGT-3' }\end{array}$ & $60^{\circ} \mathrm{C}$ & $216 \mathrm{bp}$ \\
\hline GATA6 & AM937234 & $\begin{array}{c}\text { 5'-CCGCGAGTGCGTGAACT-3' } \\
\text { 5'-CGCTTCTGTGGCTTGATGAG-3' }\end{array}$ & $60^{\circ} \mathrm{C}$ & $104 \mathrm{bp}$ \\
\hline CD31 & X98505 & $\begin{array}{c}\text { 5'-CATTTCCAAAGTCAGCAGCA-3' } \\
\text { 5'-CATCATCATGCCTCCCTTCT-3' }\end{array}$ & $56^{\circ} \mathrm{C}$ & $172 \mathrm{bp}$ \\
\hline CD34 & NM_214086 & $\begin{array}{l}\text { 5'-GGAAACCACACCAGATGCTT-3', } \\
\text { 5'-AGGTCTGAGGCTGGACAGAA-3' }\end{array}$ & $56^{\circ} \mathrm{C}$ & $164 \mathrm{bp}$ \\
\hline CD44 & XM_003122866 & $\begin{array}{c}\text { 5'-AAGGTGAGGCAAACACAACC-3' } \\
\text { 5'-AGCTTTTTCTTCTGCCCACA-3' }\end{array}$ & $56^{\circ} \mathrm{C}$ & $151 \mathrm{bp}$ \\
\hline Mesp1 & AM937233 & $\begin{array}{c}\text { 5'-GCGACATGCTGGCTCTTCTA-3' } \\
\text { 5'-TGGTATCACTGCCGCCTCTTCC-3' }\end{array}$ & $64^{\circ} \mathrm{C}$ & $175 \mathrm{bp}$ \\
\hline Mesp2 & AM937232 & $\begin{array}{c}\text { 5'-TGCCTTTATCTGCCTCTTCTG-3' } \\
\text { 5'-GGGGGTGTCTTGTCTCAGC-3' }\end{array}$ & $56^{\circ} \mathrm{C}$ & $150 \mathrm{bp}$ \\
\hline Mef2a & EF194143 & $\begin{array}{l}\text { 5'-TGGCAATCTTGGAATGAACA-3' } \\
\text { 5'-ACAGACACCACTGGGGTAGC-3' }\end{array}$ & $56^{\circ} \mathrm{C}$ & $165 \mathrm{bp}$ \\
\hline $\mathrm{Nkx} 2.5$ & NM_008700 & $\begin{array}{c}\text { 5'-TTCAAGCAACAGCGGTACC-3' } \\
\text { 5'-TAACCGTAGGGATTGAGGCC-3' }\end{array}$ & $58^{\circ} \mathrm{C}$ & $150 \mathrm{bp}$ \\
\hline ANP & X54669 & $\begin{array}{c}\text { 5'-AAGCGAGCAGAATGAGGAAG-3' } \\
\text { 5'-CAGTCCACTCTGTGCTCCAA-3' }\end{array}$ & $50^{\circ} \mathrm{C}$ & $244 \mathrm{bp}$ \\
\hline $\mathrm{Cx} 43$ & AJ293888 & $\begin{array}{l}\text { 5'- CACCAGGTGGACTGTTTCCT-3' } \\
\text { 5'- TCTTTCCCTTCACACGATCC-3' }\end{array}$ & $56^{\circ} \mathrm{C}$ & $151 \mathrm{bp}$ \\
\hline $\begin{array}{l}\text { Cardiac } \\
\text { Actinin }\end{array}$ & NM_001243666.1 & $\begin{array}{l}\text { 5'-CATGCTGCTTTTGGAAGTCA-3', } \\
\text { 5'-GGCAGAGGTTTCTTCGACTG-3' }\end{array}$ & $56^{\circ} \mathrm{C}$ & $244 \mathrm{bp}$ \\
\hline Tbx 5 & AM937230 & $\begin{array}{c}\text { 5'-GCGAAGGGATGTATCAGCAC-3' } \\
\text { 5'-GCCGTGTACCGAGTGATACTG-3' }\end{array}$ & $56^{\circ} \mathrm{C}$ & $170 \mathrm{bp}$ \\
\hline Tbx 18 & XM_001926951 & $\begin{array}{l}\text { 5'-GCCTTTGCTGCTAACCAGAC-3', } \\
\text { 5'-AACTCTGTTGACCCCCACTG-3' }\end{array}$ & $50^{\circ} \mathrm{C}$ & $238 \mathrm{bp}$ \\
\hline MyoD & U12574.1 & $\begin{array}{c}\text { 5'-TGCGTATTCTCAACCCCTTC-3' } \\
\text { 5'-AGTATGCAAGGGTGGAGTGG-3' }\end{array}$ & $60^{\circ} \mathrm{C}$ & $243 \mathrm{bp}$ \\
\hline Myf5 & XM_001924362 & $\begin{array}{l}\text { 5'-GCTCAGACGAGGAAGAGCAC-3' } \\
\text { 5'-AGCCTCTGGTTGGGGTTAGT-3' }\end{array}$ & $60^{\circ} \mathrm{C}$ & $211 \mathrm{bp}$ \\
\hline$\beta$-actin & DQ452569.1 & $\begin{array}{c}\text { 5'-CCCTCCTCTCTTGCCTCTCT-3' } \\
\text { 5'-GGGGAGTCACGTCAGACCTA-3', }\end{array}$ & $60^{\circ} \mathrm{C}$ & $296 \mathrm{bp}$ \\
\hline
\end{tabular}

Table 5. List of primers used for PCR detailing accession number, primer sequence, annealing temperature and expected amplification product size. 


\begin{tabular}{|c|c|}
\hline GENE & POSITIVE CONTROL \\
\hline c-kit & $\begin{array}{c}\text { Ovary cDNA } \\
\text { (Yoshinori Okamura et al.,2001) }\end{array}$ \\
\hline LY6G6F (Sca-1) & Genomic DNA \\
\hline Oct 4 & $\begin{array}{c}\text { Genomic DNA } \\
\text { (Brevini et al, 2010) }\end{array}$ \\
\hline Nanog & $\begin{array}{c}\text { Genomic DNA } \\
\text { (Brevini et al, 2010) }\end{array}$ \\
\hline Sox-2 & $\begin{array}{c}\text { Genomic DNA } \\
\text { (Brevini et al, 2010) }\end{array}$ \\
\hline GATA6 & $\begin{array}{c}\text { Ovary cDNA } \\
\text { (Carolina Gillio-Meina et al.,2003) }\end{array}$ \\
\hline CD31 & Genomic DNA \\
\hline CD34 & Genomic DNA \\
\hline CD44 & Genomic DNA \\
\hline Mesp1 & Muscle cDNA \\
\hline Mesp2 & Muscle cDNA \\
\hline Mef2a & $\begin{array}{c}\text { Ovary cDNA } \\
\text { (Maria D. Ivanova et al.,2003) }\end{array}$ \\
\hline Nkx2.5 & Genomic DNA \\
\hline ANP & Genomic DNA \\
\hline $\mathrm{Cx} 43$ & Genomic DNA \\
\hline Cardiac Actinin & Heart cDNA \\
\hline Tbx 5 & Heart cDNA \\
\hline Tbx18 & Heart cDNA \\
\hline MyoD & Genomic DNA \\
\hline Myf5 & Genomic DNA \\
\hline$\beta$-actin & Genomic DNA \\
\hline
\end{tabular}

Table 6. PACPs gene expression through RT-PCR analysis. The appropriate positive control was selected depending on the gene and is indicated in the far right column. 
3.5. Characterization of Pig Adult Cardiac Progenitors surface markers

PACPs were plated in 4 well dishes in complete medium and, once they reached the density of $5 \times 10^{5}$ cells $/ \mathrm{cm}^{2}$, cells were washed three times in PBS and trypsinized. PACPs were centrifuged at $1250 \mathrm{rpm}$ for 5 minutes and then the pelleted cells were putted in ice. Cells were resuspended in $100 \mu \mathrm{l}$ PBS and $1 \mu \mathrm{l}$ specific antibody for each surface marker was added followed by incubation at $4^{\circ} \mathrm{C}$ for 30 minutes. PACPs were then washed in PBS and centrifuged at $2000 \mathrm{rpm}$ for 5 minutes. Supernatants were discarded and the pelleted cells were fixed with $200 \mu \mathrm{l}$ 2\% paraformaldehyde (PFA, SigmaAldrich ${ }^{\mathrm{TM}}$, Italy) at $4^{\circ} \mathrm{C}$ for 10 minutes in the dark. Cells were then washed again in PBS and stored at $4^{\circ} \mathrm{C}$. Flow cytometry was carried out with a FACSCalibur Flow Cytometer (Beckton Dickinson, Lincolin Park, USA) and analyzed with FACSDiva v6.1.3 software. Cells incubated with primary isotypic antibody were used as a control.

The antibodies used were:

- R-Phycoerythrin (R-PE)-Conjugated Rat Anti-Mouse CD34 Monoclonal Antibody (BD Biosciences, Italy);

- Fluorescein Isothiocyanate (FITC)-Conjugated Rat Anti-Mouse CD44 Monoclonal Antibody (BD Biosciences, Italy); 
- Fluorescein Isothiocyanate (FITC)-Conjugated Mouse Anti-Mouse CD31 Monoclonal Antibody (ID Labs inc., USA);

- Fluorescein Isothiocyanate (FITC)-Conjugated Mouse Anti-Mouse CD45 Monoclonal Antibody (BD Biosciences, Italy);

- Fluorescein Isothiocyanate (FITC)-Conjugated Mouse Anti-Mouse LAlkaline Phosphatase (Santa Cruz Biotecnology, Germany). 
3.6. Pig Adult Cardiac Progenitor differentiation ability

\subsubsection{Cardiac differentiation}

PACPs cardiac differentiation ability was carried out plating cells in 4 well dishes pre-coated with $0.1 \%$ porcine gelatin at a density of $2.5 \times 105$ in the presence of $500 \mu \mathrm{l}$ complete medium, supplemented with $10 \mu \mathrm{M} 5$ '-azacytidine (Sigma, Hybri-Max ${ }^{\mathrm{TM}}$ ). The differentiation medium was changed every 48 hours for 7 days.

\subsubsection{Smooth muscle differentiation}

Differentiation ability into smooth muscle cells was also tested. In order to address PACPs towards this commitment, cells were plated in 4 well dishes pre-coated with $0.1 \%$ porcine gelatin at a density of $2.5 \times 10^{5}$ in $500 \mu \mathrm{l}$ complete medium, supplemented with $5 \mathrm{ng} / \mathrm{ml}$ transforming growth factor beta (TGF $\beta$, PeproTech, Inc, USA). 


\subsubsection{Skeletal muscle differentiation}

Skeletal muscle differentiation ability was assessed by coculturing PACPs with C2C12 myoblasts. Cells were plated at a rate of 1:5 respectively and cultured for 7 days in complete medium. After these treatments PACPs were analyzed through immunofluorescence techniques. 
3.7. Immunocytochemistry and immunofluorescence

At the end of the differentiation culture, 4 well dishes containing PACPs were washed 3 times with PBS and fixed with 4\% PFA for 10 minutes at $4^{\circ} \mathrm{C}$ for all the antibodies or with a solution composed of methanol/glacial acetic acid (1:1) for the MF20 antibody. Cells were permeabilized with $0.1 \%$ Triton X-100 (Sigma-Aldrich ${ }^{\mathrm{TM}}$, Italy) for 20 minutes at room temperature, rinsed 3 times with the solution formed by $0.1 \%$ PBS-Tween (Sigma-Aldrich ${ }^{\mathrm{TM}}$, Italy)-5\% bovine serum albumin (BSA) and then nonspecific binding sites were blocked with $10 \%$ donkey serum for 30 minutes at room temperature. Markers of muscular and cardiac cells were assessed by immunocytochemistry using the following primary antibodies:

- $\operatorname{MF20~(1:500,~Santa~Cruz,~USA);~}$

- Smooth Muscle Actin (SMA, 1:800, Santa Cruz, USA);

- $\operatorname{Desmin}(1: 200$, Chemicon, USA);

- Cx43 (1:2000, Santa Cruz, USA);

- $\quad \alpha$-Tropomyosin (1:200, Abcam, UK);

- Lamins A/C (1:200, Novocastra, UK).

Primary antibodies diluted in blocking solution composed of $10 \%$ donkey serum were incubated over-night at $4^{\circ} \mathrm{C}$. Cells were then stained and revealed usingthe appropriate secondary antibodies for 45 minutes at room temperature 
(488 and 594 Alexafluor, Invitrogen, Italy). Nuclei were stained with 4',6diamidino-2-phenylindole (DAPI). Samples were observed either under an Eclipse TE200 (Nikon, Japan) or an Eclipse E600 microscope (Nikon, Japan). 
3.8. Pig Adult Cardiac Progenitors cocultured with fetal rat cardiomyocytes

Fetal cardiomyocytes were obtained from wild-type rat embryos. Hearts were removed and the ventricles were dissected and digested with collagenase type II (108 U/ml, Worthington Biochemical Corporation, USA) and with pancreatine $\left(0.6 \mathrm{mg} / \mathrm{ml}, \mathrm{Gibco}\right.$, Italy) for 20 minutes at $37^{\circ} \mathrm{C}$. Cells were collected by centrifugation and resuspended in newborn calf serum (NBCS; Gibco, Italy). These steps were repeated until the ventricles were completely digested. Cells were collected and subjected to centrifugation through a discontinuous Percoll gradient. The middle band containing cardiomyocytes was collected. Cells were counted with Burker's chamber and then were plated on gelatin-coated $35-\mathrm{mm}$ plastic tissue culture plates at a density of $5 \times 10^{4} / 50$ $\mu \mathrm{l}$ in a culture medium consisting of a 4:1 mixture DMEM and medium 199 supplemented with 10\% HS and 5\% FBS, 1\% L-glutamine and 1\% penicillin/streptomycin. These cells were maintained at $37^{\circ} \mathrm{C}$. Cultures were then shifted, 24 hours after plating, to a maintenance medium containing both HS and FBS to a final concentration of $5 \%$ and $1 \%$ cytosine arabinoside (AraC, $10 \mathrm{mM}$ ) to kill fibroblasts and endothelial cells (all medium were from Gibco). Forty-eight hours after the plating of the cardiomyocytes, PACPs were added at different concentrations for 5 days. Cells were stained with an anti- 
Lamins A/C antibody that recognizes only pig nuclei, leaving rat cells unstained and DAPI. Fusion phenomena were scored randomly choosing 10 microscopy fields and averaged. Samples were observed under an Eclipse E600 microscope (Nikon, Japan).

\subsection{Data analysis}

All experiments were carried out three times using four replicates each and subjected to statistical analysis using ANOVA (Sigma Stat). Errors are presented as standard deviation (SD). Data with a $\mathrm{p}$ value $<0.05$ were considered statistically significant. In flow cytometry studies at least 10.000 events for each sample were counted. 


\section{4. $\underline{\text { Results }}$}

4.1. Isolation and proliferation ability of Pig Adult Cardiac Progenitors

Within 10 days from explants plating, small and poorly adhering cells appeared floating on the initial outgrowth of fibroblast-like cells adherent to the Petri dishes. These cells in suspension were collected by gently pipetting (Figure $19 \mathrm{a}-\mathrm{c})$.

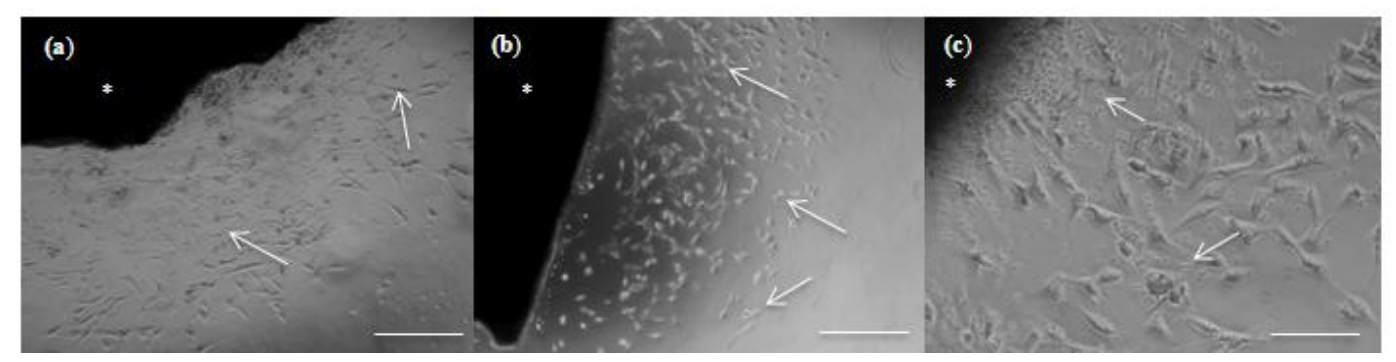

Figure 19. PACPs isolated from explants $\left(^{*}\right)$ of aorta (a), ventricle (b) and atrium (c) of healthy adult pig heart. Note the presence of rounded cells on top of fibroblast layer (arrows), bar: $100 \mu \mathrm{m}$. 
Cultures of this cell population was carried out and maintained in complete DMEM medium until senescence. We could observe that PACPs were efficiently and reproducibly obtained from aorta, ventricle and atrium regions. We termed these cells aortic, ventricular and atrial PACPs (Figure 20d-f).

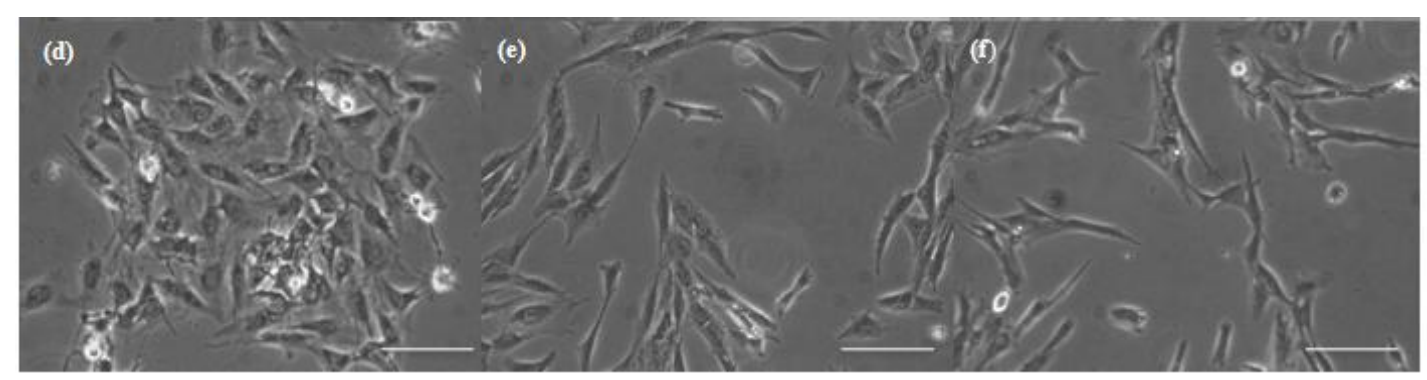

Figure 20. Growing PACPs isolated from aorta (d), ventricle (e) and atrium (f) after 8 passages in vitro, cultured in DMEM complete medium, bar: 50 $\mu \mathrm{m}$.

We analyzed the proliferation rate of the cells obtained. Four replicates for every lineage were evaluated in three separate experiments.

The results showed that PACPs have a doubling time of $35 \mathrm{~h}$ and keep a relatively slow proliferation rate for approximately 25 passages. They achieve senescence after 28 passages, when large cells appeared at increasing frequency that did not divide anymore (Figure 21g-i) (Vanelli et al. 2011) (Appendix b). 


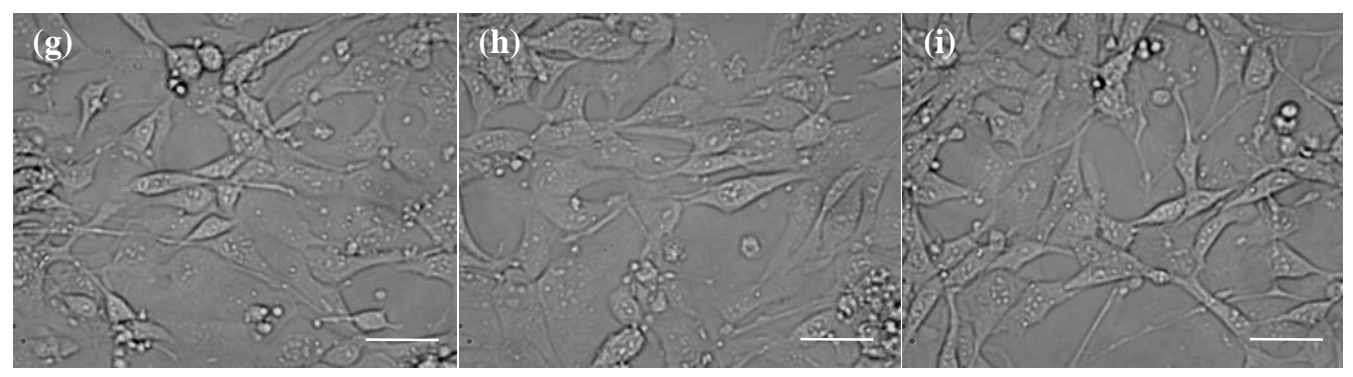

Figure 21. PACPs isolated from aorta (g), ventricle (h) and atrium (i) after 28 passages in vitro that reached senescence, bar: $20 \mu \mathrm{m}$.

Analysis of PACP ability to proliferate showed that aorta- and ventriclederived population replicate faster than cells isolated from atrium (Figure 22).

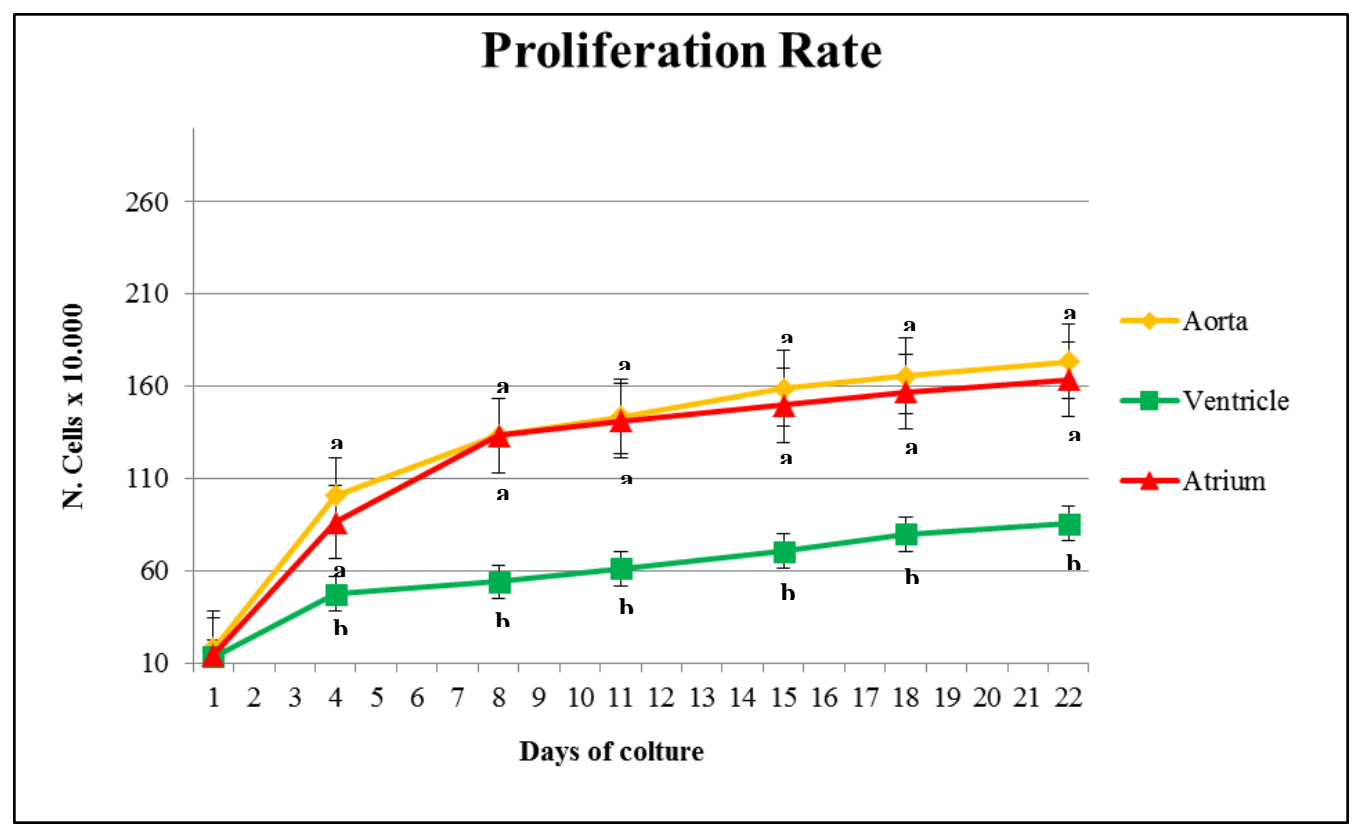

Figure 22. Proliferation curves of PACPs in complete DMEM medium. Aorta and atrium cells had a significant higher proliferation rate than those of ventricle ( $\mathrm{a} ; \mathrm{b} \mathrm{p}<0.05$ by ANOVA). 
4.2 Karyotype analysis of Pig Adult Cardiac Progenitors

Karyotype analysis demonstrated that PACPs appeared to be genetically stable and displayed the number of chromosomes typical of normal pig cells, namely 38 chromosomes (Figure 23a). The presence of normal karyotypes were confirmed when analysis was performed both at 14 and 25 passages. This allows us to exclude the presence of anomalies that could be caused by prolonged in vitro culture of PACPs (Figure 23b). We also evaluated the percentage of euploid karyotypes in relation to aneuploid karyotype in early and late passages. The results indicated that also in late passages, PACPs did not possess significant karyotype abnormalities (Figure 24) (Vanelli et al. 2011) (Appendix b).

(a)

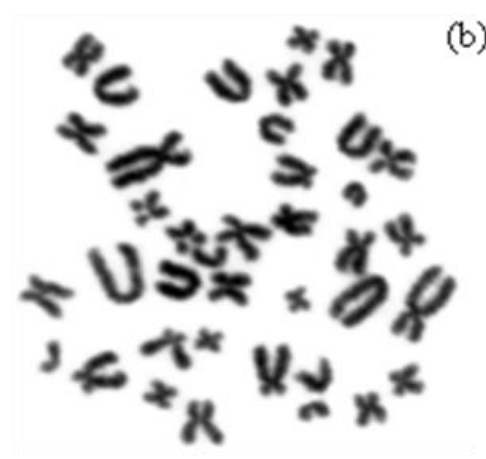

(b) $8 x \times x \times x \times x$
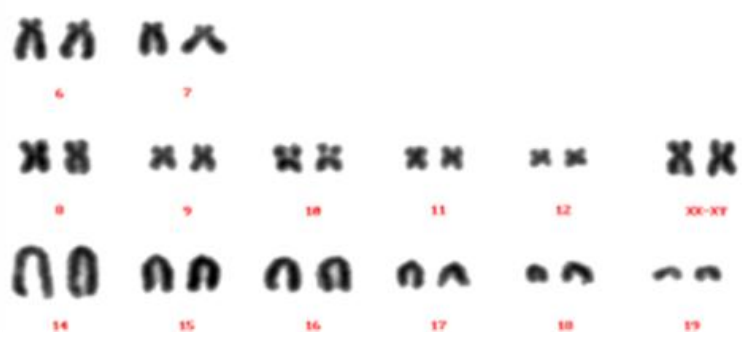

Figure 23. Representative karyotype analysis of PACPs after 14 passages (a). Cells showed the correct numbers of chromosomes, namely 38 (b). 


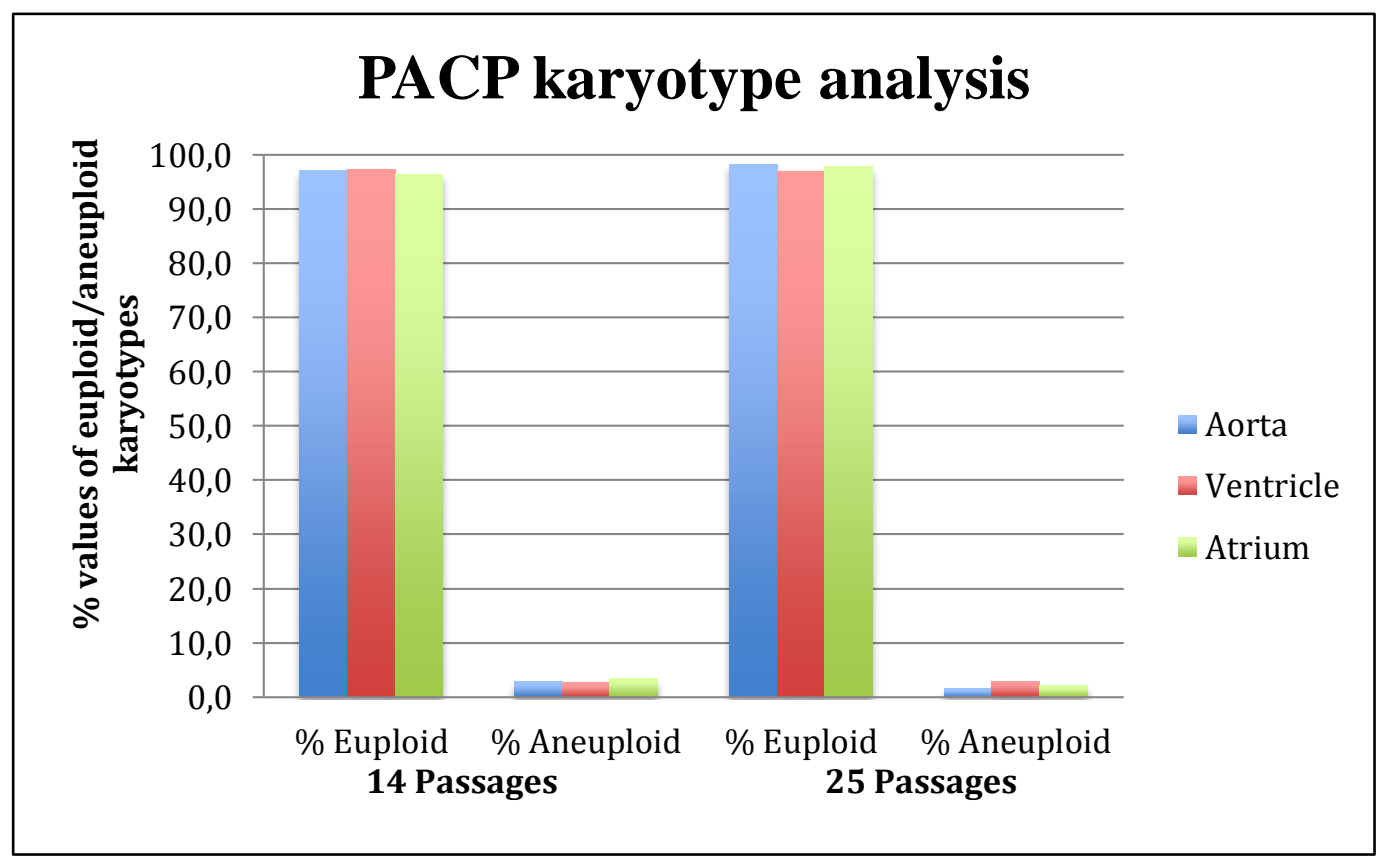

Figure 24. Percentage of euploid and aneuploid karyotypes of PACPs derived from aorta, ventricle and atrium at 14 and 25 passages. 
4.3 Characterization of Pig Adult Cardiac Progenitors surface markers

Three independent replicates of PACPs obtained from the different heart regions considered were analyzed for the presence of CD34, CD44, CD31, CD45 and Alkaline Phosphatase (AP) by flow cytometry (Figure 25-27). CD44, CD45 and AP antibodies were labeled with FITC fluorochrome while CD34 and CD31 antibodies were labeled with RED fluorochrome. The difference between the blue graph values (blank) and the black graph values (sample) gave the percentage of PACPs expressing the marker examined.

Thus, the analysis of the presence of these specific surface markers demonstrated that all cell lines examined were positive for the hematopoietic marker CD34 and for the mesenchymal marker CD44. A subpopulation of the analyzed cells expressed the endothelial marker CD31. In particular, 17.05\% of the cells in the lines obtained from aorta, 5.38\% in those derived from ventricle and $8.33 \%$ of the atrium derived populations were positive for CD31. Screening for CD45 gave not significant results in all cells of all the lines obtained, regardless to their origin. Expression of AP was restricted to a small subpopulation $(2 \%)$ of cells obtained from aorta (Vanelli et al. 2011) (Appendix b). 
(a) Flow cytometry analysis of aorta-derived cells at 10 passages

CD34
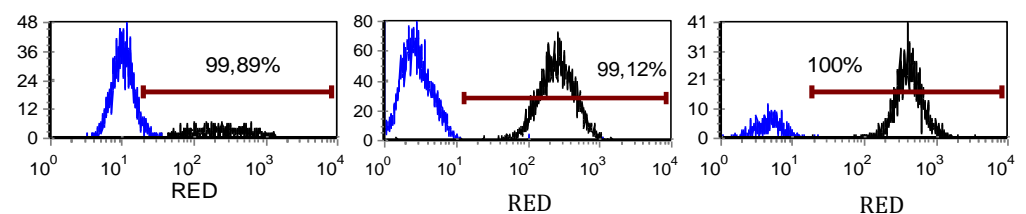

CD44
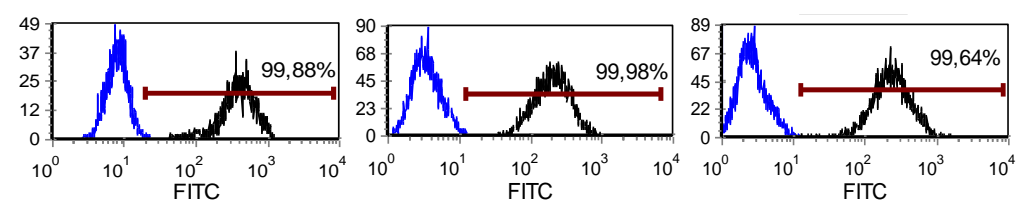

CD31
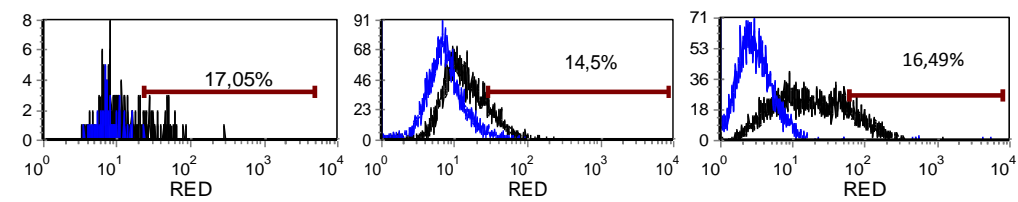

CD45
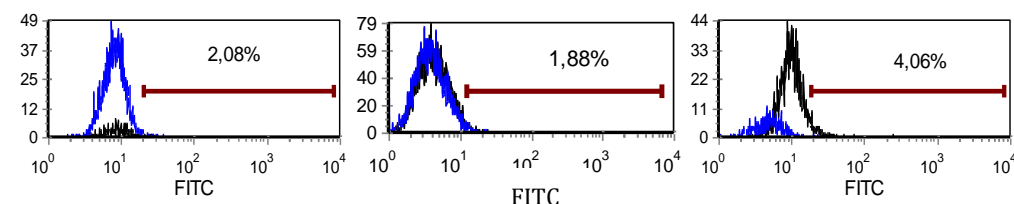

AP
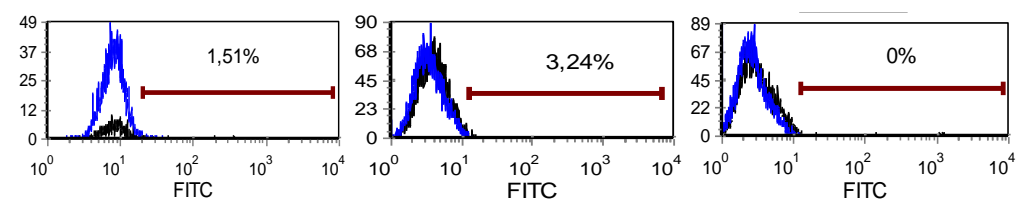

(b)

\begin{tabular}{|c|c|}
\hline Aorta & 10 passages \\
\hline CD34 & $99,67 \%$ \\
\hline CD44 & $99,83 \%$ \\
\hline CD31 & $17,05 \%$ \\
\hline CD45 & $2,67 \%$ \\
\hline AP & $1,58 \%$ \\
\hline
\end{tabular}

Figure 23. PACPs analysis of the surface markers CD34, CD44, CD31, CD45 and AP (a). Summary of the percentage values of the flow cytometry experiments carried out on aorta-derived cells at 10 passages (b). 
(a) Flow cytometry analysis of ventricle-derived cells at 10 passages

CD34
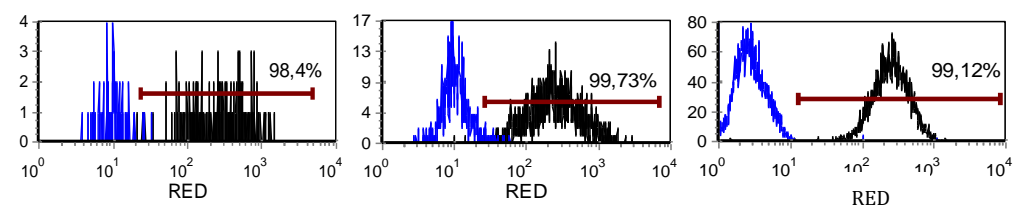

CD44
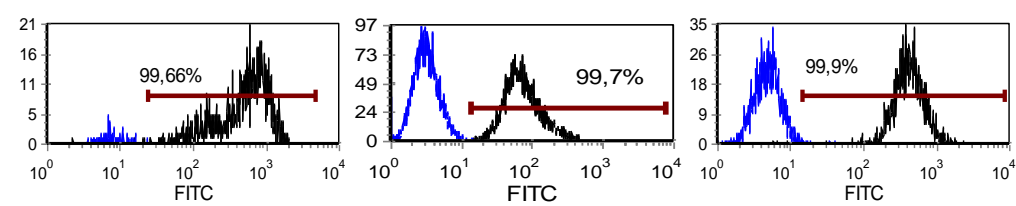

CD31
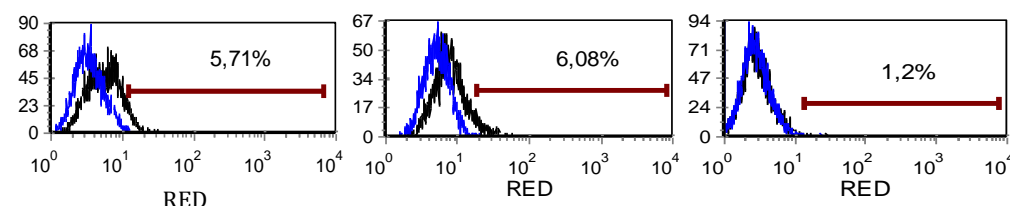

CD45
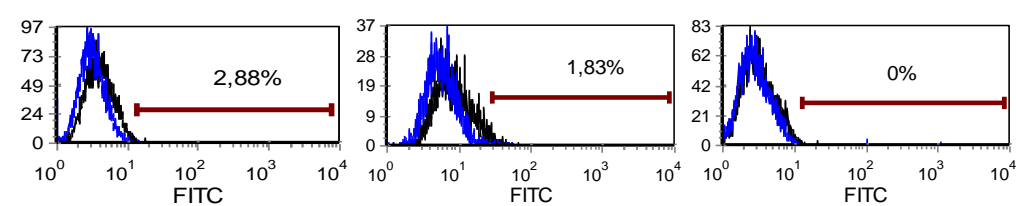

AP
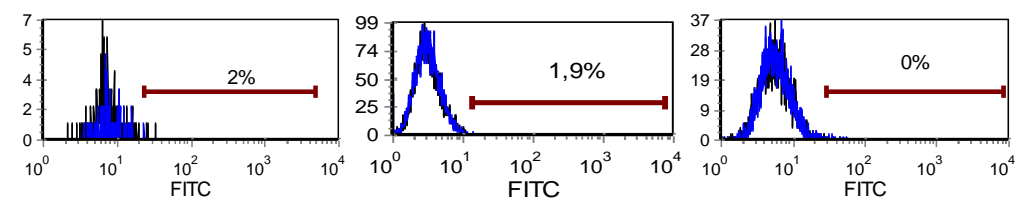

(b)

\begin{tabular}{|c|c|}
\hline Ventricle & $\mathbf{1 0}$ passages \\
\hline CD34 & $98,40 \%$ \\
\hline CD44 & $99,66 \%$ \\
\hline CD31 & $5,38 \%$ \\
\hline CD45 & $4,71 \%$ \\
\hline AP & $1,00 \%$ \\
\hline
\end{tabular}

Figure 24. PACPs analysis of the surface markers CD34, CD44, CD31, CD45 and AP (a). Summary of the percentage values of the flow cytometry experiments carried out on ventricle-derived cells at 10 passages (b). 
(a) Flow cytometry analysis of atrium-derived cells at 10 passages

CD34
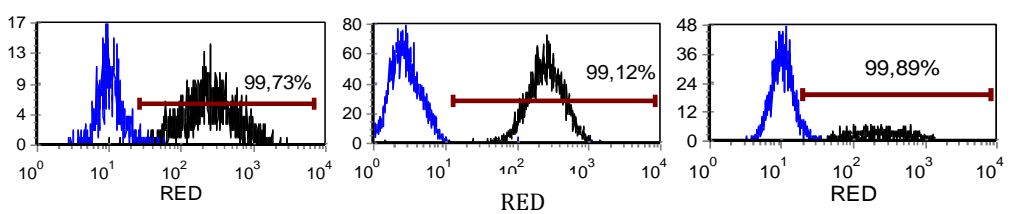

CD44
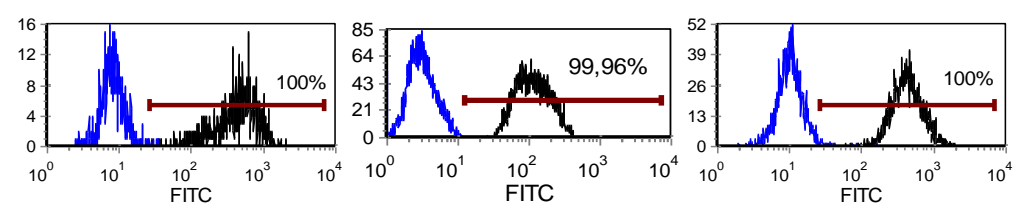

CD31
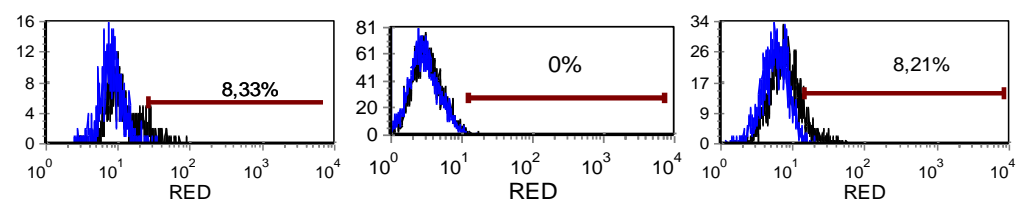

CD45
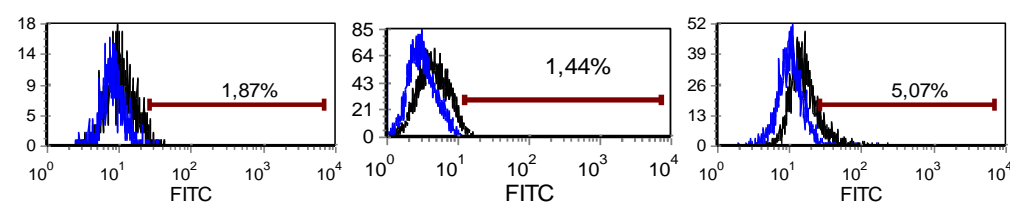

AP
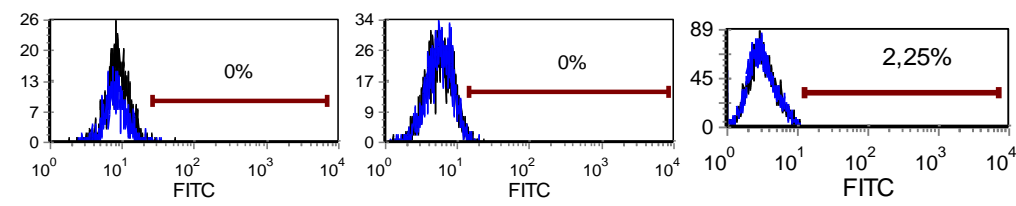

(b)

\begin{tabular}{|c|c|}
\hline Atrium & 10 passages \\
\hline CD34 & $100,00 \%$ \\
\hline CD44 & $99,96 \%$ \\
\hline CD31 & $8,33 \%$ \\
\hline CD45 & $1,46 \%$ \\
\hline AP & $0,00 \%$ \\
\hline
\end{tabular}

Figure 25. PACPs analysis of the surface markers CD34, CD44, CD31, CD45 and AP (a). Summary of the percentage values of the flow cytometry experiments carried out on atrium-derived cells at 10 passages (b). 
4.4 Gene expression analysis of Pig Adult Cardiac Progenitors

Gene expression was assessed through RT-PCR experiments. RNA was extracted from PACPs deriving from all the different heart regions considered. The results demonstrated that PACPs express genes related to pluripotency as well as genes involved in mesodermal and cardiac development (Figure 28, Table 7). In particular, PACPs expressed c-kit, Gata6, CD44, Mesp1, Mef2a and ANP while transcription of Mesp2 and Nkx2.5 was detected only in aortaand ventricular-derived cells. PACPs expressed some early endothelial markers such as CD31, suggesting a possible endothelial origin for these cells. Similarly, transcription of CD34 indicated a correlation with circulating vascular progenitor cells. RT-PCR analysis also demonstrated the expression of genes distinctive of epicardial progenitors such as Tbx5 and Tbx18. Furthermore, PACPs were positive for the pluripotency related marker Oct4, implying that these cells might belong to a residing cardiac stem cell population. On the other hand, no expression of Nanog, Sox-2 and LY6G6F (Sca-1) was detected. When exposed to the appropriate inducing media, PACPs showed positivity for $\mathrm{Cx} 43$ and Cardiac Actinin, while skeletal myogenic markers such as MyoD or Myf5 were negative in all cell lines (Figure 28, Table 7) (Vanelli et al. 2011) (Appendix b). 


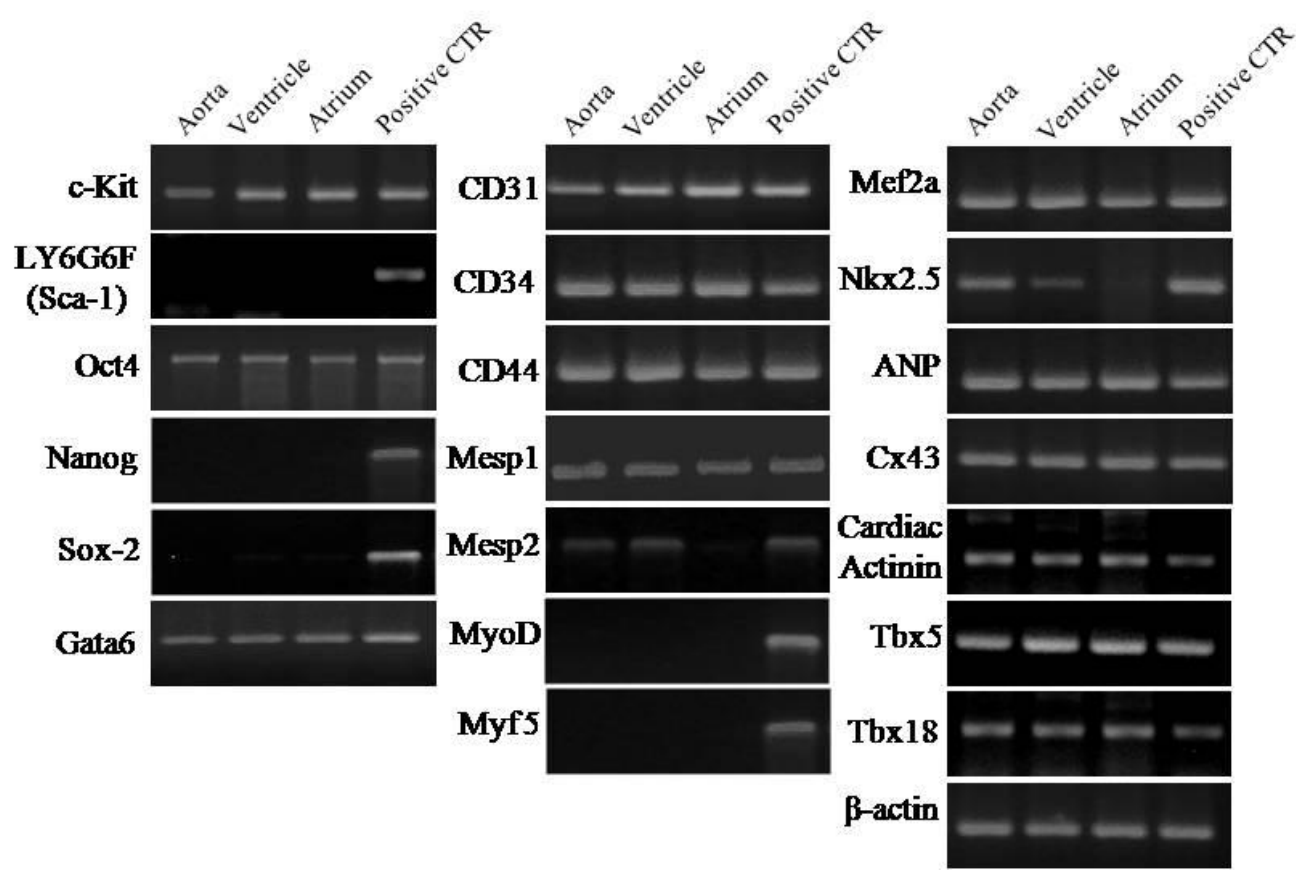

Figure 28. Expression of the genes c-kit, LY6G6F (Sca-1), Oct4, Nanog, Sox2, Gata6 (left column), CD31, CD34, CD44, Mesp1, Mesp2, MyoD, Myf5 (middle column), Mef2a, Nkx2.5, ANP, Cx43, Cardiac Actinin, Tbx5 and Tbx18 (right column), was investigated in samples from aorta, ventricle and atrium obtained from five different hearts. The appropriate positive control was used, depending on the gene considered (Table 7). Expression of $\beta$-actin was always examined as an internal control of the sample quality. 


\begin{tabular}{|c|c|c|c|}
\hline GENE & AORTA & VENTRICLE & ATRIUM \\
\hline c-kit & + & + & + \\
\hline LY6G6F (Sca-1) & - & - & - \\
\hline Oct 4 & + & + & + \\
\hline Nanog & - & - & - \\
\hline Sox-2 & - & - & - \\
\hline GATA6 & + & + & + \\
\hline CD31 & + & + & + \\
\hline CD34 & + & + & + \\
\hline $\mathrm{CD} 44$ & + & + & + \\
\hline Mesp1 & + & + & + \\
\hline Mesp2 & + & + & - \\
\hline Mef2a & + & + & + \\
\hline Nkx2.5 & + & + & - \\
\hline ANP & + & + & + \\
\hline $\mathrm{Cx} 43$ & + & + & + \\
\hline CardiacActinin & + & + & + \\
\hline Tbx5 & + & + & + \\
\hline Tbx18 & + & + & + \\
\hline MyoD & - & - & - \\
\hline Myf5 & - & - & - \\
\hline$\beta$-actin & + & + & + \\
\hline
\end{tabular}

Table 7. PACP expression of pluripotent, hematopoietic, endothelial, mesenchymal and cardiac genes. 
4.5 Differentiation ability of Pig Adult Cardiac Progenitors

PACPs were tested for their ability to differentiate into other cell types that belong to the mesoderm lineage. In particular, it was verified whether PACPs possess the ability to differentiate into smooth muscle cells and skeletal muscle cells, with particular interest to their ability to differentiate into cardiomyocytes (Vanelli et al. 2011) (Appendix b).

4.5.1. Analysis of Pig Adult Cardiac Progenitor ability to differentiate into smooth muscle

Analysis of PACP ability to differentiate into smooth muscle cells were carried out after treatment with $5 \mathrm{ng} / \mathrm{ml}$ TGF $\beta$. The results obtained through immunostaining experiments indicated that PACPs were able to differentiate into smooth muscle cells. In particular, $72 \%$ of aorta cells, $58 \%$ of ventricle cells and $71 \%$ of atrium cells displayed immunopositivity for SMA (Figure 29). 

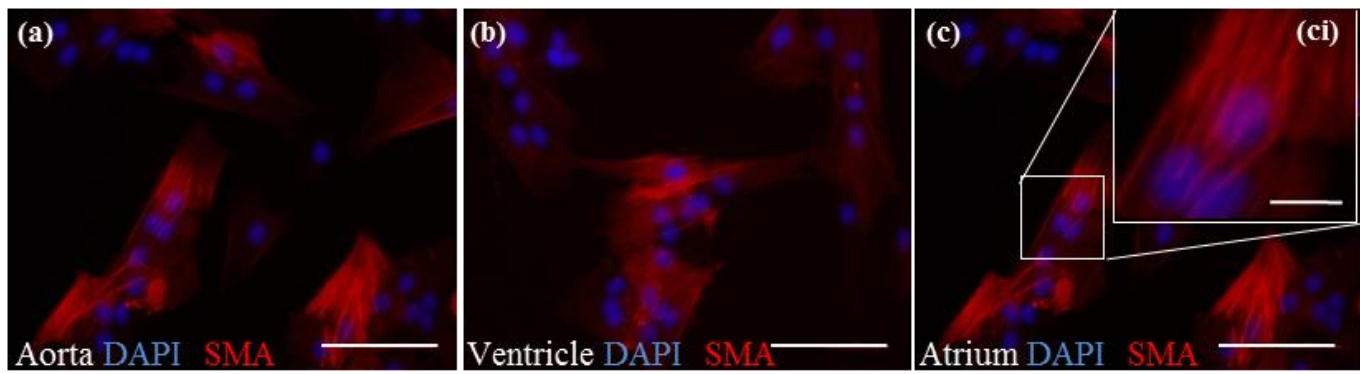

Figure 29. Staining with an anti-SMA antibody (red) showed PACP ability to differentiate into smooth muscle cells, with $72 \%$ of aorta cells, $58 \%$ of ventricle cells and $71 \%$ of atrium cells displaying immunopositivity for SMA; nuclei were stained with DAPI (blue) (a-c), bar: $50 \mu \mathrm{m}$. Insert shows SMApositive PACPs in higher magnification (ci), bar: $20 \mu \mathrm{m}$.

4.5.2. Analysis of Pig Adult Cardiac Progenitor ability to differentiate into skeletal muscle

PACPs were also tested for their ability to differentiate into skeletal muscle cells after coculture with C2C12 myoblasts for seven days. PACP differentiation was assessed after immunostaining with the specific MF20 antibody that recognizes the sarcomeric myosin. The results obtained indicated that PACPs had a poor ability (less than 1\%) to differentiate into skeletal muscle (Figure 30). These data confirmed the negative results obtained 
in the experiment section related to gene expression studies that demonstrated no transcription for MyoD and Myf5 muscular genes.

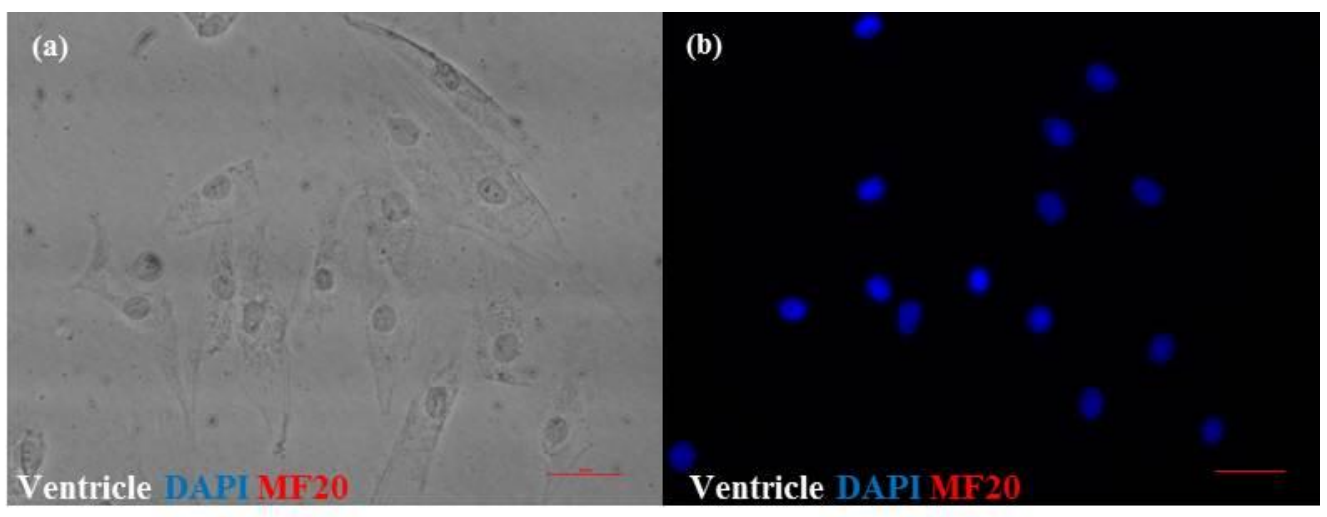

Figure 30. Representative ventricle-derived PACPs (a). Immunostaining with MF20 antibody (red) after coculture with C2C12 myoblasts demonstrated that PACPs did not differentiate into skeletal muscle (b). Cell nuclei were stained with DAPI (blue), bar: $20 \mu \mathrm{m}$. 
4.5.3. Analysis of Pig Adult Cardiac Progenitor differentiation ability into cardiomyocytes

Particular interest was addressed to the assessment of PACPs ability to differentiate into cardiomyocytes. The results obtained indicated that PACPs were not able to spontaneously differentiate into beating cardiomyocytes, even when cultured with a medium containing low serum, which has been previously shown to trigger this event in mice (Galvez et al. 2008). By contrast, they predominantly differentiated into cardiomyocytes when treated with 10 $\mu \mathrm{M}$ 5'-azacytidine, which also induced a change in cell morphology that became closer to that of genuine cardiomyocytes (Figure 31). 

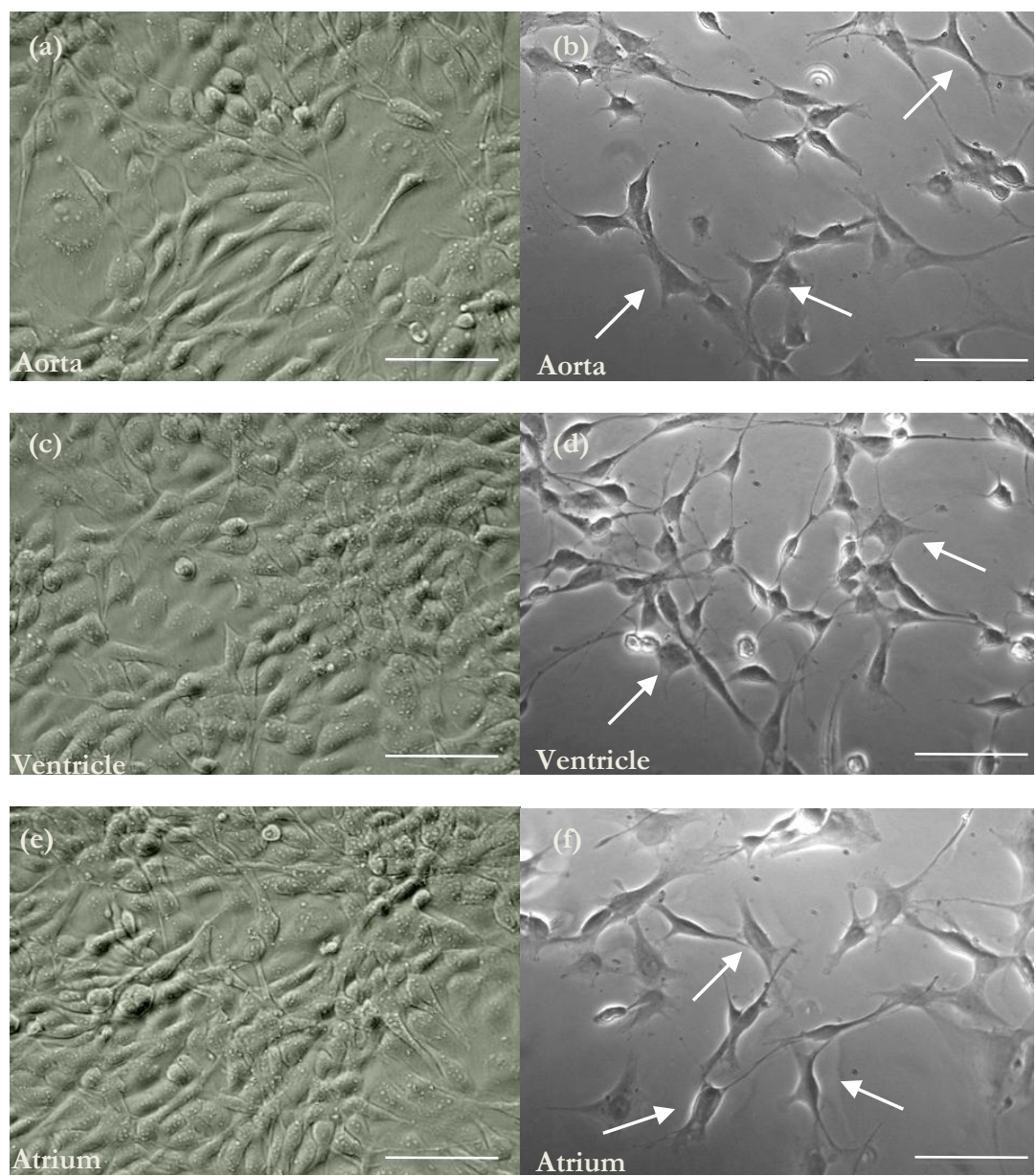

Figure 31. Morphological analysis of PACPs before (left column) and after (right column) treatment with 5'-azacytidine. PACPs acquired a morphology closer to that of cardiomyocytes. Aorta-derived cells in complete DMEM medium (a); aorta-derived cells after treatment with 5'-azacytidine (b); ventricle-derived cells in complete DMEM medium (c); ventricle-derived cells after treatment with 5'-azacytidine (d); atrium-derived cells in complete DMEM medium (e); atrium-derived cells after treatment with 5'-azacytidine (f), bars: $50 \mu \mathrm{m}$. 
In order to confirm PACPs differentiation into cardiomyocytes, immunostaining experiments were carried out using antibodies specific for skeletal muscle and cardiac proteins. In particular, staining with an antiDesmin antibody, specific for intermediate filaments found in muscle cells, showed PACP ability to progress to mesenchymal cell lineage with $96 \%$ of aorta cells, $89 \%$ of ventricle cells and $74 \%$ of atrium cells displaying positivity (Figure 32).
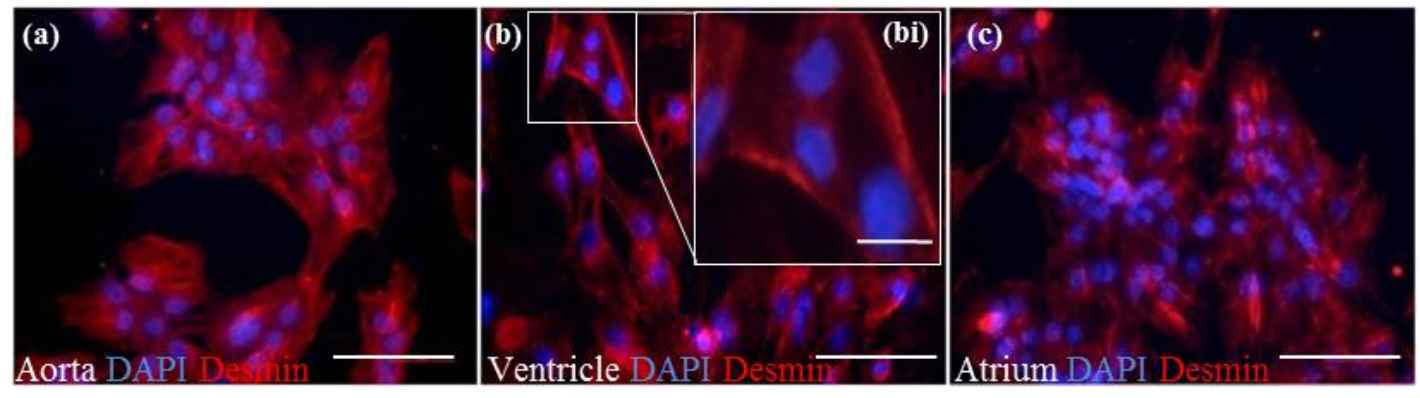

Figure 32. Staining with an anti-Desmin antibody (red) showed PACP ability to progress to mesenchymal cell lineage; cell nuclei were stained with DAPI (blue) (a-c), bar: $50 \mu \mathrm{m}$. Insert shows Desmin-positive PACPs in higher magnification (bi), bar: $20 \mu \mathrm{m}$. 
Similarly, the use of an anti-Cx43 antibody, which recognizes gap junction connecting cardiomyocytes, demonstrated that $61 \%$ of aorta cells, $30 \%$ of ventricle cells and 32\% of atrium cells formed cardiomyocytes (Figure 33). These data were supported by the fact that, after treatment with 5'-azacytidine, PACPs expressed Cx43 and Cardiac Actinin transcription factors, which have been investigated in the section related to gene expression studies through RTPCR experiments that demonstrated the transcription for $\mathrm{Cx} 43$ and Cardiac Actinin genes (Figure 28, Table 7).
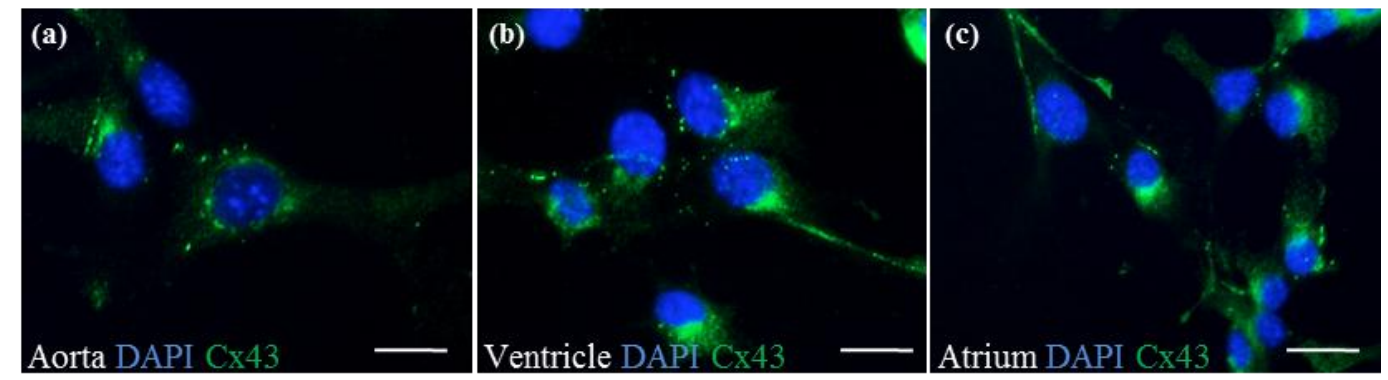

Figure 33. Immunostaining with an anti-Cx43 antibody (green) after treatment of cells with 5'-azacytidine demonstrated the PAPC ability to form cardiomyocytes. Nuclei were stained with DAPI (blue) (a-c), bar: $20 \mu \mathrm{m}$.

PACPs were also stained with Rhodamine Phalloidin, a probe conjugated to the red fluorescent dye that recognized the F-actin cytoskeleton, used to analyze the cytoskeletal organization of the cells. The results indicated that aorta- and ventricle-derived PACPs, after treatment with 5'-azacytidine, 
acquired a cytoskeletal organization similar to that of cardiomyocytes (Figure 34a,b). By contrast, atrium-derived cells did not respond to the treatment and did not display the expected morphological changes (Figure 33c).
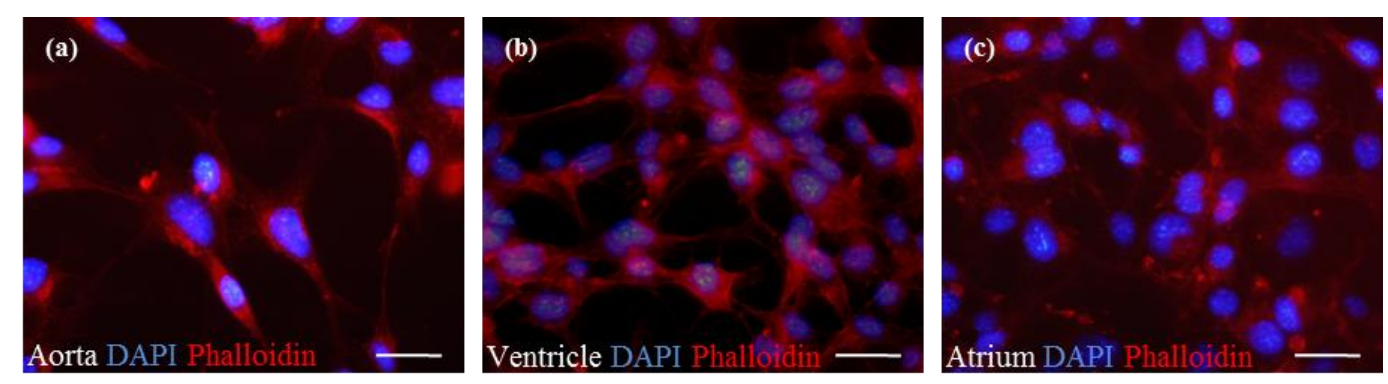

Figure 34. Immunostaining withRhodamine Phalloidin (red) after PACPs treatment with 5'-azacytidine demonstrated that aorta- and ventricle-derived cells possessed the cytoskeletric organization similar to that of genuine cardiomyocytes (a,b), in contrast to atrium-derived PACPs (c). Cell nuclei were stained with DAPI (blue), bar: $50 \mu \mathrm{m}$.

These data were confirmed after staining with the specific MF20 antibody, which recognizes the sarcomeric myosin (Figure 35), and an anti- $\alpha$ Tropomyosin antibody, which binds the tropomyosin protein associated with actin filaments, both typical of contractile structures of the skeletal muscle (Figure 36). 


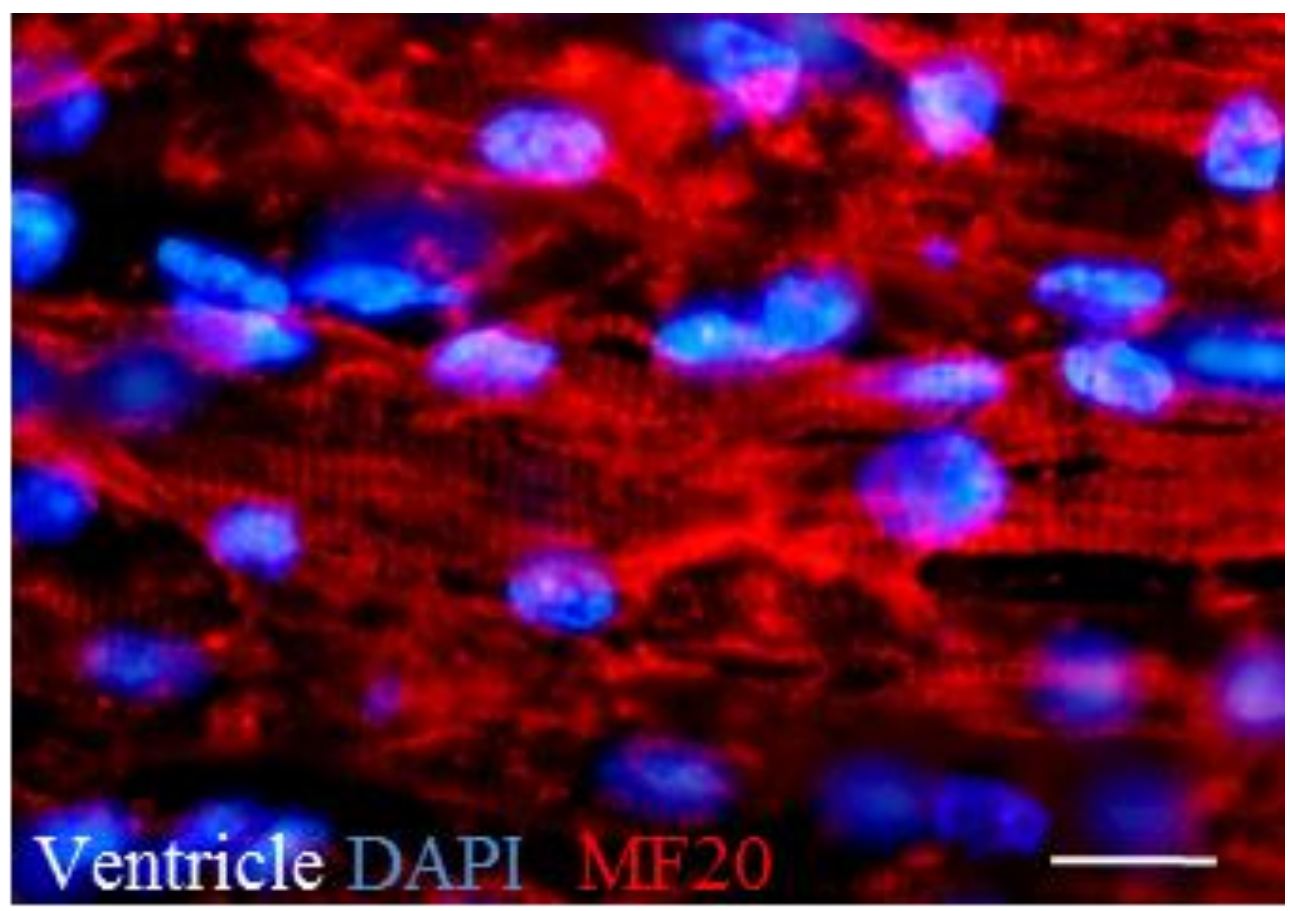

Figure 35. Representative ventricle-derived PACPs. Immunostaining with MF20 antibody (red) after treatment with 5'-azacytidine demonstrated PACPs ability to differentiate into cardiomyocytes characterized by the correct sarcomeric contractile structures. Cell nuclei were stained with DAPI (blue), bar: $20 \mu \mathrm{m}$. 


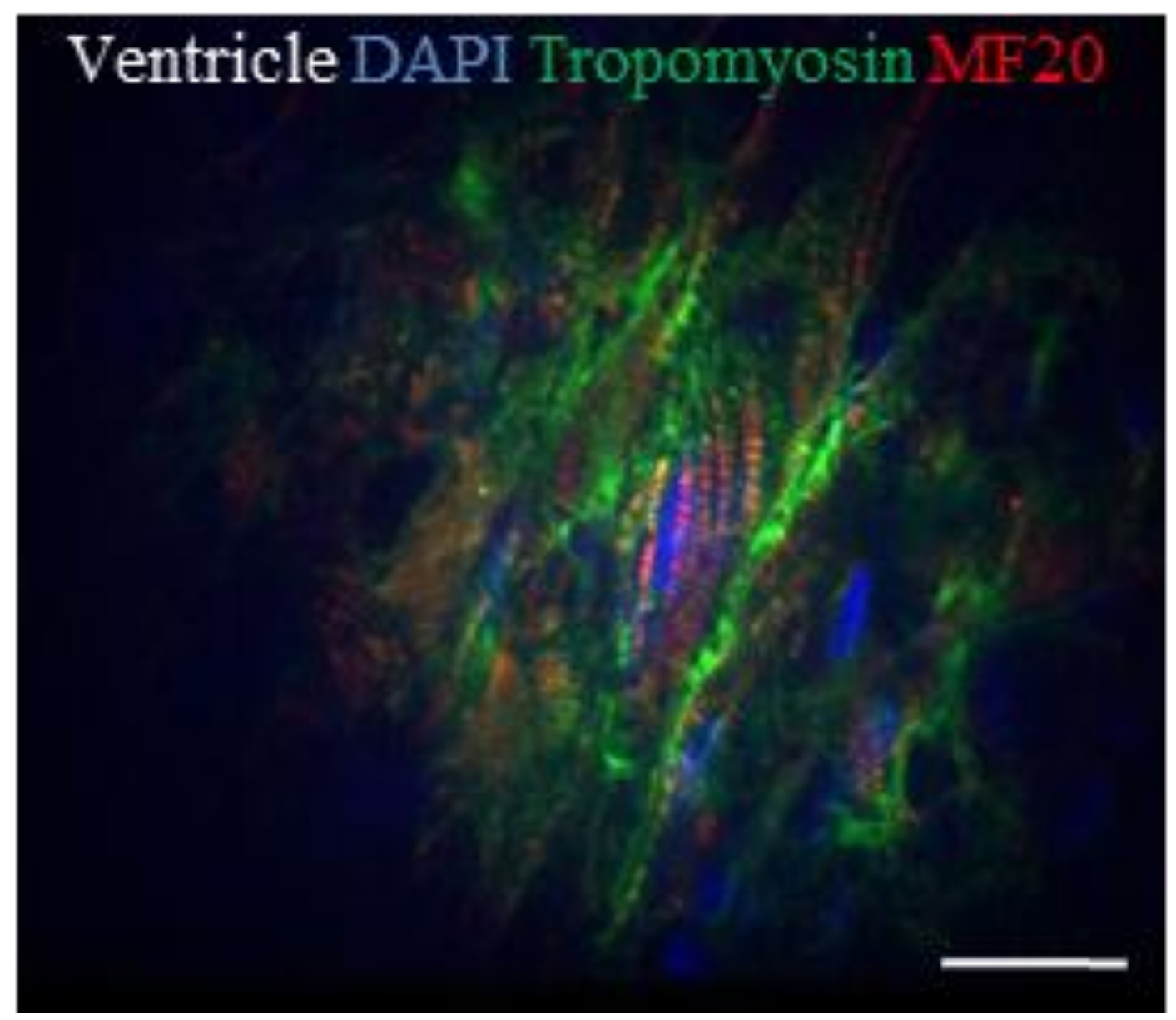

Figure 36. Representative ventricle-derived PACPs immunostaining with MF20 (red) and $\alpha$-Tropomyosin (green) antibody after treatment with 5'azacytidine showing PACP ability to differentiate into cardiomyocytes. Cell nuclei were stained with DAPI (blue), bar: $20 \mu \mathrm{m}$. 
4.6 Fusion ability of Pig Adult Cardiac Progenitors

Coculture with fetal rat cardiomyocytes demonstrated PACP ability to give rise to fusion events. However, this property appeared to be limited to aorta- and ventricle-derived PACPs that gave rise to $5 \%$ fusion rate with rat cardiomyocytes (Figure 37). Atrium-derived cells appeared to lack this ability since no fusion event was detected (data not shown). Fusion phenomena were scored in 10 microscopy fields and averaged. 

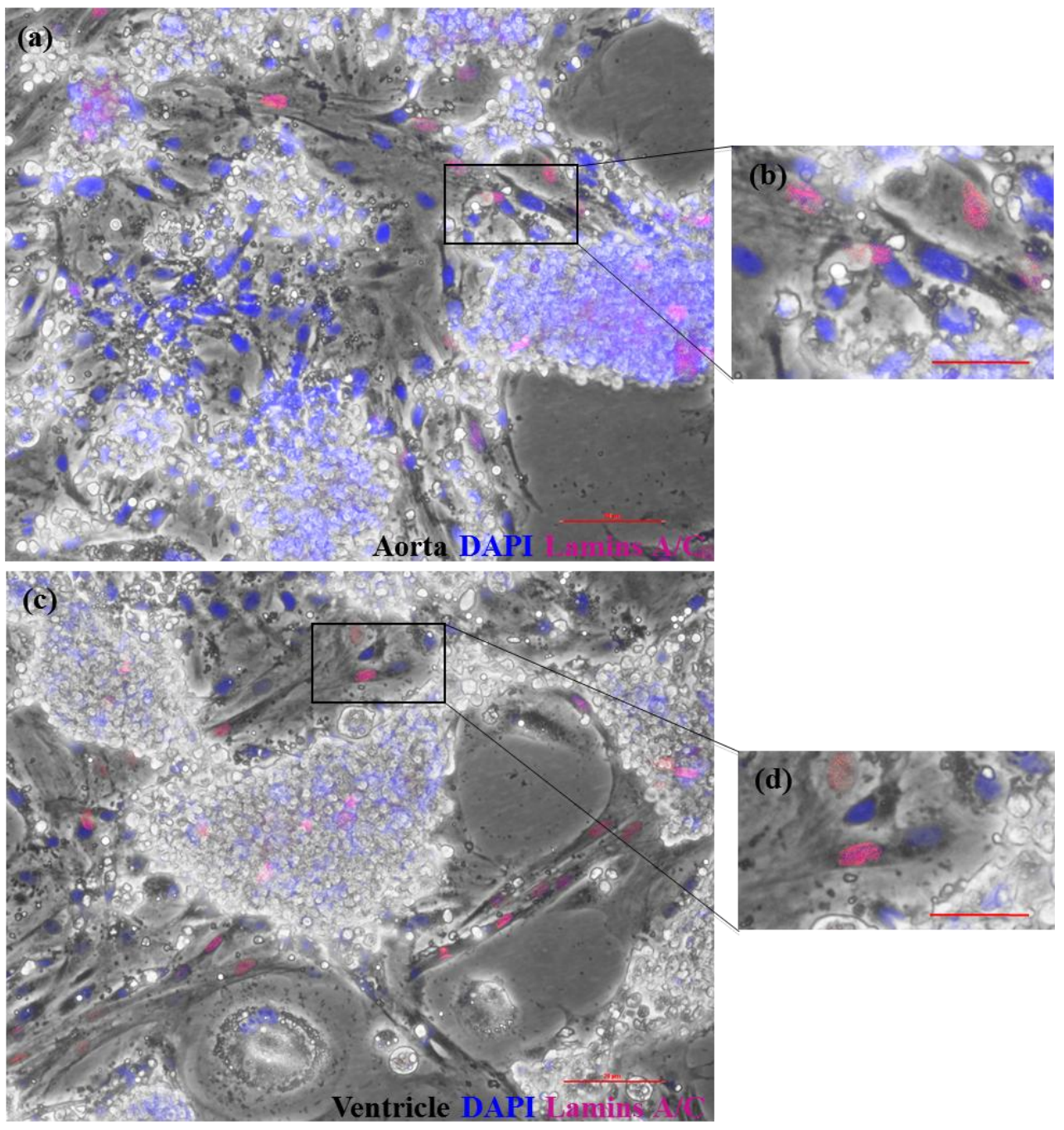

Figure 37. PACP coculture with rat fetal cardiomyocytes. Both rat and pig nuclei stained with DAPI (blue). However, Lamins A/C antibody (red) only recognized pig nuclei, leaving rat cells unstained. Coexistence of blue and pink nuclei within a cell demonstrated fusion event. A fusion rate of $5 \%$ for aorta(a, representative image) and ventricle-derived cells (c, representative image), bar: $50 \mu \mathrm{m}$. Higher magnification of aorta and ventricle fusion events $(\mathrm{b}, \mathrm{d})$, bar: $20 \mu \mathrm{m}$. 


\section{Discussion}

The development of an effective regenerative therapy of the heart is not likely to be achieved in the near future since clinical and animal studies show that true cardiac regeneration does involve more complex aspects than injecting the right type of cells in the right place (Segers et al. 2008).

Unfortunately, the experiments carried out until now were predominantly performed on mice and humans. This restricts significantly the possibility to apply the results obtained in preclinical studies that cannot be performed using the human as a model and, at the same time, are limited by the evident differences between mouse and humans. Consequently, to improve human health, large animal models that approximate human physiology, function, and anatomy, are essential to develop discoveries from murine models into clinical therapies and interventions.

Large animal models have a well-established role in cardiovascular research and the derivation of different types of cardiogenic stem cells in different species indicated that these models could certainly provide a substantial contribution to the development of cell therapies.

In the last few years, several groups described many different cardiac stem/progenitor cells in different species with high phenotypic and molecular variability. It is unclear whether they represent specific differentiation stages of 
a common multipotent cardiovascular progenitor cell population, whether they result from different methods of isolation, culture media and anatomical origin or whether they are genuine, distinct and specific cardiac progenitors, coexisting in the organ.

Cardiogenic stem cells of porcine origin have been object of intense studies. In particular, mesenchymal stem cells obtained in this species have been widely used to explore new delivery methods (Liu et al. 2004) and resulted in successful engraftment and differentiation into cardiomyocytes (Makkar et al. 2005). Cardiogenic stem cells have also been derived from pig adipose tissue (Valina et al. 2007) and from amniotic fluid-derived mesenchymal cells (Sartore et al. 2005).

In the present thesis, we report the derivation of adult cardiac progenitor cells from adult healthy pig hearts. We show the possibility to isolate cardiac progenitors from three different heart regions, such as aorta, ventricle and atrium, respectively (Figure 19-22). This observation indicates that this subpopulation of committed, but still proliferating, cardiac progenitor cells are not confined to a specific region within the organ, but rather distributed to several areas.

However, our results indicate that PACPs are unlikely to derive from the inner regions since the starting explants were obtained from the outer layers of the organ. This is consistent with experimental data, indicating the epicardium as a 
possible site of origin for resident stem or progenitor cell populations in the mouse and in the human. Recently, in fact, a novel cardiogenic precursor marked by the expression of the transcription factor Wt1 and Tbx18 and located within the epicardium were isolated and characterized (Zhou et al. 2008). These cells, termed epicardium-derived progenitor cells (EPDCs), expressed Nkx2.5 transcription factor and differentiate into a number of mature cardiovascular cell types, including vascular smooth muscle cells, cardiomyocytes, and, arguably, some endothelial cells (Smart et al. 2009; Smart et al. 2011). According to these evidences, we analyzed the presence of Tbx18 and Tbx5 and confirmed their expression in our cells. Since these T-box genes are expressed in the epicardial cell layer of the heart and its progenitors (Plageman et al. 2005; Kraus et al. 2001; Hatcher et al. 2004; Tanaka et al. 2004), PACPs may belong to an epicardial progenitor population (Figure 28, Table 7).

PACPs were able to grow in vitro until senescence and displayed a chromosomal set up typical of the porcine species. A normal karyotype was preserved unaffected along the culture passaging, suggesting that the protocol used to isolate, maintain and propagate PACPs in vitro was not affecting cell stability and/or inducing chromosomal alterations (Figure 23, 24). Unexpectedly, PACPs expressed the pluripotent marker Oct4 (Figure 28, Table 7). In the literature, Torella et al. already reported the expression of 
Oct4 in the mammalian heart. This group proposed that specific regions, defined harbours, contain Oct4 positive cells that belong to the cardiac stem cell pool and may represent the true resident stem cells in the organ. The expression of Oct4 gave to these cells the ability to differentiate into real cardiomyocytes, smooth muscle cells, endothelial cells and in other mesoderm cell types when grown with the appropriate media (Torella et al. 2006). Although this must be further investigated, we may hypothesize that PACPs might belong to this residing cardiac stem cell population, because of these similarities with the cardiac stem cells described by Torella's group.

At the same time, PACPs showed the expression of genes specific of mesenchymal stem cells (MSCs), such as CD44 (Carlson et al. 2011), Mesp1 (Saga et al. 1999; Kitajima et al. 2000) and Mesp2 (Kitajima et al. 2000) (Figure 28, Table 7). This indicates that PACPs are likely to have a mesodermal origin and display part of the transcription pattern, which has been previously described in mouse and human MSCs (Saga et al. 1999; Kitajima et al. 2000; Pittenger et al. 1999; Pittenger et al. 2004). Mesenchymal stem cells of different origin have proved to be readily available also in large animal models and showed the same properties of their human counterpart. Furthermore, similarly to MSCs, which have the ability to differentiate into different mesoderm-related cell types, including muscle tissue (Pittenger et al. 1999; Pittenger et al. 2004), PACPs were able to efficiently differentiate into smooth 
muscle cells in response to TGF $\beta$, with a high percentage of cells displaying immunopositivity for SMA (Figure 29). In contrast, gene expression analysis of PACPs did not show skeletal myogenic-related transcripts, such as MyoD and Myf5 (Figure 28, Figure 30, Table 7) (Beltrami et al. 2003; Galvez et al. 2008).

This was supported by the immunonegativity for a specific MF20 antibody, indicating the inability of these cells to differentiate into striated muscle tissue. It is however interesting to note that the concomitant expression of specific endothelial and hematopoietic markers, such as CD31 and CD34 (Figure 2325), suggests that PACPs might have a possible vascular origin or a close association with the vessel wall. This data was confirmed through RT-PCR analysis, which showed the positivity of CD31 and CD34 transcription factors (Figure 28, Table 7). The result is also in agreement with data previously described that shows the isolation from mice of a cell population that has the ability to differentiate into cardiomyocytes, endothelial cells and vascular smooth muscle cells (Galvez et al. 2008; Bearzi et al. 2007). It has also been suggested that, during the pre-and postnatal development, cells derived from the growing vessels maintain a multipotent state that allows them to acquire a cardiac phenotype, indicating in vitro transdifferentiation of endothelial cells into heart cells (Condorelli et al. 2001). 
Although PACPs share some molecular and functional properties with MSCs, they also express genes representative of early and late cardiac transcription factors, such as Gata6 (Koutsourakis et al. 1999), Mef2a (Potthoff et al. 2007), Nkx2.5 (Arminan et al. 2009; Arminan et al. 2010) and ANP (Guan et al. 1999; Miller-Hance et al. 1993), respectively (Figure 28, Table 7), indicating that they are part of a progenitor population addressed to the formation of the cardiac mesoderm (Rajala et al. 2011). This gene expression pattern is possibly involved in conferring PACPs the ability to respond to specific stimuli and further differentiate along the cardiac lineage. However, consistent with previous experiments carried out in human mesoangioblasts, human embryonic stem cells and human MSCs (Galvez et al. 2009; Yoon et al. 2006; Balana et al. 2006), PACPs were unable to spontaneously differentiate into beating cardiomyocytes, as it happens in the mouse (Galvez et al. 2008; Fukuda et al. 2001). On the other hand, after exposure to 5'-azacytidine, they acquired the positivity for $\mathrm{Cx} 43$ (Figure 33) (Bayes-Genis et al. 2005; Hierlihy et al. 2002) and Cardiac Actinin (Wainwright et al. 2010) (Figure 28, Table 7), which are typical of differentiated cardiomyocytes and are required to establish electrical intercellular connections between atrial and ventricular myocytes and essential for cardiac contraction (Hierlihy et al. 2002; Lobe et al. 2002; BayesGenis et al. 2005). Furthermore, after this treatment, PACPs progressed to cells that showed a change in the morphology (Figure 31), which became more 
similar to that of cardiomyocytes, and in the cytoskeletal organization, as demonstrated by the immunopositivity for Desmin (Figure 32), F-actin (Figure 34), myosin (Figure 35) and tropomyosin (Figure 36). These proteins are important in maintaining cardiomyocytes contractile structure (Srinivasan et al. 2011), although this property appeared to be limited to PACPs isolated from aorta- and ventricle. These findings altogether indicate that PACPs have a higher similarity with cardiac progenitors derived from the human species (Galvez et al. 2009; Yoon et al. 2006; Balana et al. 2006).

Moreover, in the recent years, several authors have considered fusion ability as a marker of differentiation in vitro (Galvez et al. 2009; Minasi et al. 2002; Galvez et al. 2008; Galli et al. 2005; Leri et al. 2005). Indeed, cell fusion experiments further demonstrated PACP ability to differentiate in vitro and to give rise to fusion events, reflecting a distinct property common to many types of cardiac progenitors, although this property appeared to be limited to aortaand ventricle-derived cells (Figure 37). In particular, PACPs showed 5\% rate of fusion events, consistent with previous data obtained using different cell types, such as mouse embryonic stem cells, human MSCs and human cardiac stem cells, that reported similar fusion efficiency (Pittenger et al. 2004; Christoforou et al. 2010; Acquistapace et al. 2005). On the other hand, much higher fusion rate has been previously described for human and mouse mesoangioblasts (Galvez et al. 2009; Galvez et al. 2008; Galli et al. 2005). 
Although we have no ready explanation for this variability, we may hypothesize that different cell types may lead to dissimilar fusion results. Furthermore, species-related diversities cannot be ruled out.

During the preparation of the present thesis an exhaustive study has reported the isolation of a c-kit ${ }^{+}$CD45- cardiogenic cell population from weanling pigs (Ellison et al. 2011), demonstrating a strong regenerative effect of these cells that are most likely involved in the myocardium hyperplastic growth and maturation to adulthood, consistent with data previously shown in neonatal mice (Zaruba et al. 2010). PACPs display a high molecular affinity, such as ckit, Oct3/4, Sox-2, CD45, CD34 and Nkx2.5, and share many differentiation abilities, such as smooth muscle and endothelial cells, with this resident cardiac

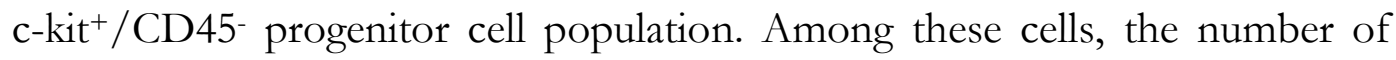
committed myogenic progenitors (c-kitpos/Nkx2.5pos cells) significantly increased in the infarct and border regions of the treated hearts in a dosedependent manner.

Altogether, the data presented in this thesis indicate the possibility that, although more abundant and active in the neonatal and post weaning period, cells with cardiogenic properties can also be isolated in the heart of adult pig. 


\section{6. $\underline{\text { References }}$}

Acquistapace, A., Bru, T., Lesault, P.F., Figeac, F., Coudert, A.E., le Coz, O. et al. (2011). Human mesenchymal stem cells reprogram adult cardiomyocytes toward a progenitor-like state through partial cell fusion and mitochondria transfer. Stem Cells, 29:812-824.

Aggarwal, S., Pittenger, M.F. (2005). Human mesenchymal stem cells modulate allogeneic immune cell responses. Blood, 105:1815-22.

Allen, W.E. and Wilson, D.J. (1993). Early embryonic angiogenesis in the chick area vasculosa. J. Anat., 183:579-585.

Amado, L.C., Saliaris, A.P., Schuleri, K.H., St. John, M., Xie, J.S.,Cattaneo, S., Durand, D.J., Fitton, T., Kuang, J.Q., Stewart, G., Lehrke, S., Baumgartner, W.W., Martin, B.J., Heldman, A.W., Hare, JM. (2005). Cardiac repair with intramyocardial injection of allogeneic mesenchymalstem cells after myocardial infarction. Proc. Natl. Acad. Sci.USA, 102:11474-9. 
Anderson, D., Self, T., Mellor, I.R., Goh, G., Hill, S.J., Denning, C. (2007). Transgenic Enrichment of Cardiomyocytes From Human Embryonic Stem Cells. Mol. Ther., 15:2027-36.

Anderson, R.H., Webb, S., Brown, N.A., Lamers, W., Moorman A. (2003). Development of the heart: septation of the atriums and ventricles. Heart, 89:949-958.

Andree, B., Duprez, D., Vorbusch, B., Arnold, H.H., Brand, T. (1998). BMP-2 induces ectopic expression of cardiac lineage markers and interferes with somite formation in chicken. Mech. Dev., 70:119-131.

Arminan, A., Gandia, C., Bartual, M., García-Verdugo, J.M., Lledó, E., Mirabet, V. et al. (2009). Cardiac differentiation is driven by NKX2.5 and GATA4 nuclear translocation in tissue-specific mesenchymal stem cells. Stem Cells Dev., 18:907-918. 
Arminan, A., Gandia, C., García-Verdugo, J.M., Lledó, E., Mullor, J.L., Montero, J.A. et al. (2010). Cardiac transcription factors driven lineagespecification of adult stem cells. J. Cardiovasc. Transl. Res., 3:61-65.

Bachiller, D., Klingensmith, J., Shneyder, N., Tran, U., Anderson, R., Rossant, J., De Robertis, E.M. (2003). The role of chordin/Bmp signals in mammalian pharyngeal development and Di George syndrome. Development, 130:35673578.

Baker, L.C., London, B., Choi, B.R., Koren, G., Salama, G. (2000). Enhanced dispersion of repolarization and refractoriness in transgenic mouse hearts promotes reentrant ventricular tachycardia. Circ. Res., 86:396-407.

Balana, B., Nicoletti, C., Zahanich, I., Graf, E.M., Christ, T., Boxberger, S. et al. (2006). 5'-azacytidine induces changes in electrophysiological properties of human mesenchymal stem cells. Cell Res., 16:949-960. 
Bartosh, T.J., Wang, Z., Rosales, A.A., Dimitrijevich, S.D., Roque, R.S. (2008). 3D-model of adult cardiac stem cells promotes cardiac differentiationand resistance to oxidative stress. J. Cell Biochem., 105:612-23.

Bartunek, J., Croissant, J.D., Wijns, W., Gofflot, S., de Lavareille, A.,Vanderheyden, M., Kaluzhny, Y., Mazouz, N., Willemsen, P., Penicka, M., Mathieu, M., Homsy, C., De Bruyne, B., McEntee, K., Lee, I.W., Heyndrickx, G.R. (2007). Pretreatment of adult bone marrow mesenchymal stem cells with cardiomyogenic growth factors and repair of the chronically infarcted myocardium. Am.J .Physiol.-Heart Circ. Physiol., 292:H1095-104.

Bayes-Genis, A., Roura, S., Soler-Botija, C., Farré, J., Hove-Madsen, L., Llachet, A. et al. (2005). Identification of cardiomyogenic lineage markers in untreated human bone marrow-derived mesenchymal stem cells. Transplant Proc., 37:4077-4079.

Bazan, J.F., Fletterick, R.J. (1989). Comparative analysis of viral cysteine protease structural models. FEES Left, 249:5-7. 
Bazan, J.F. (1991). Neuropoietic cytokines in the hematopoietic fold. Neuron, 7:197-208.

Bearzi, C., Rota, M., Hosoda, T., Tillmanns, J., Nascimbene, A., De Angelis, A. et al. (2007). Human cardiac stem cells. Proc. Natl. Acad. Sci. USA, 104:14068-14073.

Behfar, A., Faustino, R.S., Arrell, D.K., Dzeja, P.P., Perez-Terzic, C., Terzic, A. (2008). Guided stem cell cardiopoiesis: discovery and translation. J. Mol. Cell Cardiol., 45:523-9.

Beltrami, A.P., Barlucchi, L., Torella, D., Baker, M., Limana, F., Chimenti, S. et al. (2003). Adult cardiac stem cells are multipotent and support myocardial regeneration. Cell, 114:763-776.

Bergmann, O., Bhardwaj, R.D., Bernard, S., Zdunek, S., Barnabé-Hieder, F., Walsh, S. et al. (2009). Evidence for cardiomyocyte renewal in humans. Science, 324:98-102. 
Bers, D.M. (2000). Calcium fluxes involved in control of cardiac myocyte contraction. Circ. Res., 87:275-281.

Bertho, E., Gagnon, G. (1964). A comparative study in three dimension of the blood supply of the normal interventricular septum in human, canine, bovine, porcine, ovine and equine heart. Dis. Chest, 46:251-62.

Bhakta, S., Greco, N.J., Finney, M.R., Scheid, P.E., Hoffman, R.D., Joseph, M.E., Banks, J.J., Laughlin, M.J., Pompili, V.J. (2006). The safety of autologous intracoronary stem cell injections in a porcine model of chronic myocardial ischemia. J. Invasive Cardiol., 18:212-8.

Bjornson, C.R., Rietze, R.L., Reynolds, B.A., Magli, M.C. and Vescovi, A.L. (1999). Turning brain into blood: a hematopoietic fate adopted by adult neural stem cells in vivo. Science, 283:534-537. 
Bi, W., Drake, C.J., Schwartz, J. (1999). The transcription factor MEF2C-null mouse exhibits complex vascular malformation and reduced cardiac expression of angiopoietin1 and VEGF. Dev. Biol., 211:255-267.

Bianco, P. and Cossu, G. (1999). Uno, nessuno e centomila: searching for the identità of mesodermal progenitors. Exp. Cell. Res., 251:257-263.

Blankesteijn, W.M., Creemers, E., Lutgens, E., Cleutjens, J.P., Daemen, M.J., Smith, J.F. (2001). Dynamics of cardiac wound healing following myocardial infarction: observations in genetically altered mice. Acta Physiol. Scand., $173: 75-82$.

Blau, H.M., Brazelton, T.R., Weimann, J.M. (2001). The evolving concept of a stem cell: entity or function? Cell, 105:829-841.

Boudoulas, K.D., Hatzopoulos, A.K. (2009). Cardiac repair and regeneration: the Rubik's cube of cell therapy for heart disease. Dis. Model Mech., 2:344-58. 
Brazelton, T.R., Rossi, F.M., Keshet, G.I. and Blau, H.M. (2000). From marrow to brain: expression of neuronal phenotypes in adult mice. Science, 290:1775-1779.

Buckingham, M., Montarras, D. (2008). Skeletal muscle stem cells. Curr. Opin. Genet. Dev., 18:330-6.

Burdon, T., Stracey, C., Chambers, I., Nichols, J. and Smith, A. (1999). Suppression of SHP-2 and ERK signalling promotes self-renewal of mouse embryonic stem cells. Dev. Biol., 210:30-43.

Bustad, L.K. and McClellan, R.O. (1966). Swine in biomedical research. Science, 152:1526-1530.

Cai, C.L., Liang, X., Shi, Y., Chu, P.H., Pfaff, S.L., Chen, J. and Evans, S. (2003). Isl1 identifies a cardiac progenitor population that proliferates prior to differentiation and contributes a majority of cells to the heart. Dev. Cell, 5:877-889. 
Carlson, S., Trial, J., Soeller, C., Entman, M.L. (2011). Cardiac mesenchymal stem cells contribute to scar formation after myocardial infarction. Cardiovasc. Res., 91:99-107.

Chambers, I., Colby, D., Robertson, M., Nichols, J., Lee, S., Tweedie, S., Smith, A. (2003). Functional expression cloning of Nanog, a pluripotency sustaining factor in embryonic stem cells. Cell, 113:643-55.

Chau, M.D., Tuft, R., Fogarty, K., Bao, Z.Z. (2006). Notch signaling plays a key role in cardiac cell differentiation. Mech. Dev., 123:626-640.

Chien, K.R. (2003). Genotype, phenotype: upstairs, downstairs in the family of cardiomyopathy. J. Clin. Invest., 111:175-178.

Christoforou, N., Oskouei, B.N., Esteso, P., Hill, C.M., Zimmet, J. M., Bian, W. et al. (2010). Implantation of mouse embryonic stem cell-derived cardiac progenitor cells preserves function of infarcted murine hearts. PLoS One, 5:e11536. 
Clarke, D.L., Johansson, C.B., Wilbertz, J., Veress, B., Nilsson, E., Karlstrom, H., Lendahl, U., Frisen, J. (2000). Generalized potential of adult stem cells. Science, 288:1660-1663.

Condorelli, G., Borello, U., De Angelis, L., Latronico, M., Sirabella, D., Coletta, M. et al. (2001). Cardiomyocytes induce endothelial cells to transdifferentiate into cardiac muscle: implications for myocardium regeneration. PNAS, 98:10733-10738.

Cooper, D.K.C., Ye, Y., Rolf, L.L., Zuhdi, N. (1991). The pig as potential organ donor for man (ed. Cooper DKC, Kemp E, Reemtsma K, White DJG), pp. $480-500$.

Crick, S.J., Sheppard, M.N., Ho, S.Y., Gebstein, L., Anderson, R.H. (1998). Anatomy of the pig heart: comparisons with normal human cardiac structure. J. Anat., 193:105-119. 
De Angelis L., Berghella, L., Coletta, M., Lattanti, L., Zanchi, M., Cusella-De Angelis, G., Ponzetto, C., Cossu, G. (1999). Skeletal myogenic progenitors originating from embryonic dorsal aorta coexpress endothelial and myogenic markers and contribute to postnatal muscle growth and regeneration. J. Cell. Biol., 147:869-878.

Di Francesco, D., Ferroni, A., Mazzanti, M., Tromba, C. (1986). Properties of the hyperpolarizing-activated current (if) in cells isolated from the rabbit sinoatrial node. Journ. Physiol., 377:61-88.

Di Lisi, R., Millino, C., Calabria, E., Altruda, F., Schiaffino, S., Ausoni, S. (1998). Combinatorial cis-acting elements control tissue specific activation of the cardiac troponin I in vitro and in vivo. J. Biol. Chem., 273:25371-25380.

Dixon, J.A. and Spinale, F.G. (2009). Large animal models of heart failure: a critical link in the translation of basic science to clinical practice. Circ. Heart Fail, 2:262-271. 
Doevendans, P.A., Daemen, M.J., de Muinck, E.D., Smits, J.F. (1998). Cardiovascular phenotyping in mice. Cardiovasc. Res., 39:34-49.

Douglas, W.R. (1972). Of pigs and men and research: a review of applications and analogies of the pig, sus scrofa, in human medical research. Space Life Sci., 3:226-234.

Doyle, B., Sorajja, P., Hynes, B., Kumar, A.H., Araoz, P.A., Stalboerger, P.G., Miller, D., Reed, C., Schmeckpeper, J., Wang, S., Liu, C., Terzic, A., Kruger, D., Riederer, S., Caplice, N.M. (2008). Progenitor cell therapy in a porcine acute myocardial infarction model induces cardiac hypertrophy, mediated by paracrine secretion of cardiotrophic factors including TGFbeta1. Stem Cells Dev., 17:941-51.

Dyce, Sack and Wensing (1987). Textbook of veterinary anatomy. 
Durocher, D., Charron, F., Warren, R., Schwartz, R.J., Nemer, M. (1997). The cardiac transcription factors $\mathrm{Nkx} 2.5$ and GATA-4 are mutual cofactors. EMBO J., 16:5687-5696.

Ellison, G.M., Torella, D., Dellegrottaglie, S., Perez-Martinez, C., Perez de Prado, A. et al. (2011). Endogenous cardiac stem cell activation by insulin-like growth factor-1/hepatocyte growth factor intracoronary injection fosters survival and regeneration of the infarcted pig heart. J. Am. Coll. Cardiol., doi:10.1016/j.jacc.2011.05.013.

Elzinga, W.E. (1969). Ameroid constrictor: uniform closure rates and a calibration procedure. J. Appl. Physiol., 27:419-421.

Ferrara, N. (2000). Vascular endothelial growth factor and the regulation of angiogenesis. Recent. Prog. Horm. Res., 55:15-35. 
Ferrari, G., Cusella-De Angelis, G., Coletta, M., Paolucci, E., Stornaiuolo, A., Cossu, G. and Mavilio, F. (1998). Muscle regeneration by bone marrowderived myogenic progenitors. Science, 279:1528-1530.

Fujiwara, Y., Browne, C.P., Cunniff, K., Goff, S.C., Orkin, S.K. (1996). Arrested development of embryonic red cell precursors in mouse embryos lacking transcription factor GATA-1. Proc. Natl. Acad. Sci. USA., 93:1235512358.

Fukuda, K. (2001). Development of regenerative cardiomyocytes from mesenchymal stem cells for cardiovascular tissue engineering. Artif. Organs, 25:187-193.

Galli, D., Innocenzi, A., Staszewsky, L., Zanetta, L., Sampaolesi, M., Bai, A., Martinoli, E., Carlo, E., Balconi, G., Fiordaliso, F., Chimenti, S., Cusella, G., Dejana, E., Cossu, G., Latini, R. (2005). Mesoangioblasts, vessel-associated multipotent stem cells, repair the infarcted heart by multiple cellular mechanisms. A comparison with bonemarrow progenitors, fibroblasts, and endothelial cells. Arterioscler. Thromb. Vasc. Biol., 25:692-697. 
Galvez, B.G., Sampaolesi, M., Barbuti, A., Crespi, A., Covarello, D., Brunelli, S. et al. (2008). Cardiac mesoangioblasts are committed, self-renewable progenitors, associated with small vessels of juvenile mouse ventricle. Cell Death Differ., 15:1417-1428.

Galvez, B.G., Covarello, D., Tolorenzi, R., Brunelli, S., Dellavalle, A., Crippa, S. et al. (2009). Human cardiac mesoangioblasts isolated from hypertrophic cardiomyopathies are greatly reduced in proliferation and differentiation potency. Cardiovasc Res., 83:707-716.

Gandolfi, F., Vanelli, A., Pennarossa, G., Rahaman, M., Acocella, F., Brevini, T.A.L. (2011). Large animal models for cardiac stem cell therapies. Theriogenology, 75:1416-1425.

Garg, V., Kathiriya, I.S., Barnes, R., Schluterman, M.K., King, I.N., Butler, C.A. (2003). GATA-4 mutations cause human congenital heart defects and reveal an interaction with TBX5. Nature, 424:443-447. 
Ghostine, S., Carrion, C., Souza, L.C., Richard, P., Bruneval, P., Vilquin, J.T., Pouzet, B., Schwartz, K., Menasche, P., Hagege, A.A. (2002). Long-term efficacy of myoblast transplantation on regional structure and function after myocardial infarction. Circulation, 106:I131-36.

Gilbert, S.F. (2000). Developmental biology, 6th edition.

Gnecchi, M., Zhang, Z., Ni, A., Dzau, V.J. (2008). Paracrine mechanisms in adult stem cell signaling and therapy. Circ. Res., 103:1204-19.

Gorman, J.H., Gorman, R.C., Plappert, T., Jackson, B.M., Hiramatsu, Y., St John-Sutton, M.G., Edmunds, L.H. Jr. (1998). Infarct size and location determine development of mitral regurgitation in the sheep model. J. Thorac. Cardiovasc. Surg., 115:615-22.

Grepin, C., Robitaille, L., Antakly, T., Nemer, M. (1995). Inhibition of transcription factor GATA-4 expression blocks in vitro cardiac muscle differentiation. Mol. Cell Biol., 15:4095-4102. 
Guan, K., Rohwedel, J., Wobus, A.N. (1999). Embryonic stem cell differentiation models: cardiogenesis, myogenesis, neurogenesis, epithelial and vascular smooth muscle cell differentiation in vitro. Cytotechnology, 30:211226.

Guiney, E.J. (1965). The pig as an experimental animal with particular reference to cardiovascular surgery. Ir. J. Med. Sci., 474:273-280.

Hamamoto, H., Gorman, J.H., Ryan, L.P., Hinmon, R., Martens, T.P., Schuster, M.D., Plappert, T., Kiupel, M., St John-Sutton, M.G., Itescu, S., Gorman, R.C. (2009). Allogeneic mesenchymal precursor cell therapy to limit remodeling after myocardial infarction: the effect of cell dosage. Ann. Thorac. Surg., 87:794-801.

Harvey, R.P. (2002). Patterning the vertebrate heart. Nat. Rev. Genet., 3:544556. 
Hatcher, C.J., Diman, N.Y., Kim, M.S., Pennisi, D., Song, Y., Goldstein, M.M., Mikawa, T., Basson, C.T. (2004). A role for Tbx5 in proepicardial cell migration during cardiogenesis. Physiol. Genom., 18:129-140.

He, G., Zhang, H., Wei, H., Wang, Y., Zhang, X., Tang, Y., Wei, Y., Hu, S. (2007). In vivo imaging of bone marrow mesenchymal stem cells transplanted into myocardium using magnetic resonance imaging: a novel method to trace the transplanted cells. Int. J. Cardiol., 114:4-10.

Heinrich, P.C., Behrmann, I., Muller-Newen, G., Schaper, F., Graeve, L. (1998). Interleukin-6-type cytokine signaling through the gp130/Jak/STAT pathway. Biochem. J., 334:297-314.

Hierlihy, A.M., Seale, P., Lobe, C.G., Rudnicki, M.A., Megeney, L.A. (2002). The post-natal heart contains a myocardial stem cell population. FEBS Lett, 530:239-243. 
Hoeben, A., Landuyt, B., Highley, M.S., Wildiers, H., Van Oosterom, A.T., De Bruijn, E.A. (2004). Vascular endothelial growth factor and angiogenesis. pharmacol. Rev., 56:549-580.

Hosoda, T., Kajstura, J., Leri, A., Anversa, P. (2010). Mechanisms of myocardial regeneration. Circ. J., 74:13-7.

Hsieh, P.C., Segers, V.F., Davis, M.E., MacGillivray, C., Gannon, J., Molkentin, J.D. (2007). Evidence from a genetic fate-mapping study that stem cells refresh adult mammalian cardiomyocytes after injury. Nat. Med., 13:970974.

Hughes, H.C. (1986). Swine in cardiovascular research. Lab. Anim. Sci., 36:348-350.

Jackson, K.A., Mi, T., Goodell, M.A. (1999). Hematopoietic potential of stem cells isolated from murine skeletal muscle. Proc. Natl. Acad. Sci., 96:144482144486. 
Jiang, Y. and Evans, T. (1996). The Xenopus GATA-4/5/6 genes are associated with cardiac specification and can regulate cardiac-specific transcription during embryogenesis. Dev. Biol., 174:258-270.

Jensen, U.B., Lowell, S. and Watt, F.M. (1999). The spatial relationship between stem cells and their progeny in the basal layer of human epidermis: a new view based on whole mount labelling and lineage analysis. Development, 126:2409-2418.

Jirmanova, L., Afanassieff, M., Gobert-Gosse, S., Markossian, S. and Savatier, P. (2002). Differential contributions of ERK and PI3-kinase to the regulation of cyclin D1 expression and to the control of the G1/S transition in mouse embryonic stem cells. Oncogene, 21:5515-5528.

Jugdutt, B.I. and Menon, V. (2004). Valsartan-induced cardioprotection involves angiotensin II type 2 receptor upregulation in dog and rat models of in vivo reperfused myocardial infarction. J. Card. Fail, 10:74-82. 
Kajstura, J., Rota, M., Whang, B., Cascapera, S., Hosoda, T., Bearzi, C., Nurzynska, D., Kasahara, H., Zias, E., Bonafe, M., Nadal-Ginard, B., Torella, D., Nascimbene, A., Quaini, F., Urbanek, K., Leri, A., Anversa, P. (2005). Bone marrow cells differentiate in cardiac cell lineages after infarction independently of cell fusion. Circ. Res., 96:127-137.

Kalfa, D., Bel, A., Chen-Tournoux, A., Della Martina, A., Rochereau, P., Coz, C., Bellamy, V., Bensalah, M., Vanneaux, V., Lecourt, S., Mousseaux, E., Bruneval, P., Larghero, J., Menasche, P. (2010). A polydioxanone electrospun valved patch to replace the right ventricular outflow tract in a growing lamb model. Biomaterials, 31:4056-63.

Kamihata, H., Matsubara, H., Nishiue, T., Fujiyama, S., Tsutsumi, Y., Ozono, R., Masaki, H., Mori, Y., Iba, O., Tateishi, E., Kosaki, A., Shintani, S., Murohara, T., Imaizumi, T., Iwasaka, T. (2001). Implantation of bone marrow mononuclear cells into ischemic myocardium enhances collateral perfusion and regional function via side supply of angioblasts, angiogenic ligands, and cytokines. Circulation, 104:1046-52. 
Kaushal, S., Schneider, J.W., Nadal-Ginard, B., Mahdavi, V. (1994). Activation of the myogenic lineage by MEF2A, a factor that induces and cooperates with MyoD. Science, 266:1236-1240.

Kelley, C., Blumberg, H., Zon, L.I., Evans, T. (1993). GATA-4 is a novel transcription factor expressed in endocardium of the developing heart. Development, 118:817-827.

Kitajima, S., Takagi, A., Inoue, T., Saga, Y.(2000). MesP1 and MesP2 are essential for the development of cardiac mesoderm. Development, 127:32153226.

Klug, M.G., Soonpaa. M.H., Koh,G.Y., Field, L.J. (1996). Genetically selected cardiomyocytes from differentiating embryonic stem cells form stable intracardiac grafts. J. Clin. Invest., 98:216-224. 
Koyanagi, M., Haendeler, J., Badorff, C., Brandes, R.P., Hoffmann, J., Pandur, P., Zeiher, A.M., Kuhl, M., Dimmeler, S. (2005). Non-canonical Wnt signaling enhances differentiation of human circulating progenitor cells to cardiomyogenic cells. J. Biol. Chem., 280:16838-16842.

Koutsourakis, M., Langeveld, A., Patient, R., Beddington, R., Grosveld, F. (1999). The transcription factor GATA6 is essential for early extraembryonic development. Development, 126:723-732.

Kraitchman, D.L., Heldman, A.W., Atalar, E., Amado, L.C., Martin, B.J., Pittenger, M.F., Hare, J.M., Bulte, J.W. (2003). In vivo magnetic resonance imaging of mesenchymal stem cells in myocardial infarction. Circulation, 107:2290-3.

Kraus, F., Haenig, B., Kispert, A. (2001). Cloning and expression analysis of the mouse T-box gene Tbx18. Mech. Dev., 100:83-86. 
Krause, D.S., Theise, N.D., Collector, M.I., Henegariu, O., Hwang, S., Gardner, R., Neutzel, S. and Sharkis, S.J. (2001). Multi-organ, multilineage engraftment by a single bone marrow-derived stem cell. Cell, 105:369-377.

Kuisk, I.R., Li, H., Tran, D., Capetanaki, Y. (1996). A single MEF2 site governs desmin transcription in both heart and skeletal muscle during mouse embryogenesis. Dev. Biol., 174:1-13.

Kushwaha, S.S., Fallon, J.T., Fuster, V. (1997). Restrictive cardiomyopathy. New England Journal of Medicine, 336:267-276.

Iannello, R.C., Mar, J.H., Ordahl, C.P. (1991). Characterization of a promoter element required for transcription in myocardial cells. J. Biol. Chem., 266:3309-3316.

Ieda, M., Fu, J.D., Delgado-Olguin, P., Vedantham, V., Hayashi, Y., Bruneau, B.G., Srivastava, D. (2010). Direct reprogramming of fibroblasts into functional cardiomyocytes by defined factors. Cell, 142:375-86. 
Inou, T., Tomoike, H., Watanabe, K., Kikuchi, Y., Mizukami, M., Kurozumi, T., and Nakamura, M. (1980). A newly developed x-ray transparent ameroid constrictor for study on progression of gradual coronary stenosis. Basic Res. Cardiol., 75:537-543.

Itskovitz-Eldor, J., Schuldiner, M., Karsenti, D., Eden, A., Yanuka, O., Amit, M., Soreg, H., Benvenisty, N. (2000). Differentiation of human embryonic stem cells into embryoid bodies compromising the three embryonic germ layers. Mol. Med., 6:88-95.

Laflamme, M.A., Chen, K.Y., Naumova, A.V., Muskheli, V., Fugate, J.A., Dupras, S.K., Reinecke, H., Xu, C., Hassanipour, M., Police, S., O’Sullivan, C., Collins, L., Chen, Y., Minami, E., Gill, E.A., Ueno, S., Yuan, C., Gold, J., Murry, C.E. (2007). Cardiomyocytes derived from human embryonic stem cells in pro-survival factors enhance function of infarcted rat hearts. Nat. Biotech., 25:1015. 
Laflamme, M.A., Zbinden, S., Epstein, S.E., Murry, C.E. (2007). Cellbasedcardiac repair: pathophysiologic mechanisms. Annu. Rev. Pathol. Mech. Dis., $2: 307$.

Lagasse, E., Connors, H., Al-Dhalimy, M., Reitsma, M., Dohse, M., Osborne, L., Wang, X., Finegold, M., Weissman, I. L. and Grompe, M. (2000). Purified hematopoietic stem cells can differentiate into hepatocytes in vivo. Nat. Med., 6:1229-1234.

Laugwitz, K.L., Moretti, A., Lam, J., Gruber, P., Chen, Y., Woodard, S., Lin, L.Z., Cai, C.L., Lu, M.M., Reth, M., Platoshyn, O., Yuan, J.X., Evans, S., Chien, K.R. (2005). Postnatal isl1+ cardioblasts enter fully differentiated cardiomyocyte lineages. Nature, 433:647-653.

Laugwitz, K.L., Moretti, A., Caron, L., Nakano, A., Chien, K.R. (2008). Islet1 cardiovascular progenitors: a single source for heart lineages? Development, 135:193-205. 
Laverriere, A.C., MacNeill, C., Mueller, C., Poelmann, R.E., Burch, J.B., Evans, T. (1994). GATA-4/5/6, a subfamily of three transcription factors transcribed in developing heart and gut. J. Biol. Chem., 269:23177-23184.

Leobon, B., Garcin, I., Menasche, P., Vilquin, J.T., Audinat, E., Charpak, S. (2003). Myoblasts transplanted into rat infarcted myocardium are functionally isolated from their host. Proc. Natl. Acad. Sci. USA, 100:7808-11.

Leri, A., Kajstura,J., Anversa, P. (2005). Cardiac stem cells and mechanisms of myocardial regeneration. Physiol. Rev., 85:1373-1416.

Li, J., Stouffs, M., Serrander, L., Banfi, B., Bettiol, E., Charnay, Y., Steger, K., Krause, K.H., Jaconi, M.E. (2006). The NADPH oxidase NOX4 drives cardiac differentiation: role in regulating cardiac transcription factors and MAP kinase activation. Mol. Biol. Cell., 17:3978-3988.

Li, L. and Xie, T. (2005). Stem cell niche: structure and function. Annu. Rev. Cell Dev. Biol., 21:605-31. 
Lien, C.L., McAnally, J., Richardson, J.A., Olson, E.N. (2002). Cardiac specific activity at an Nkx2.5 enhancer requires an evolutionarily conserved Smad binding site. Dev. Biol., 244:257-266.

Lin, Q., Schwartz, J., Bucana, C., Olson, E.N. (1997). Control of mouse cardiac morphogenesis and myogenesis by transcription factor MEF2C. Science, 276:1404-1407.

Lin, J.H., Huang, S.Y., Lee, W.C., Liu, S.K., Chu, R.M. (2002). Echocardiographic features of pigs with spontaneous hypertrophic cardiomyopathy. Comp. Med., 52:238-42.

Linke, A., Muller, P., Nurzynska, D., Casarsa, C., Torella, D., Nascimbene, A., Castaldo, C., Cascapera, S., Bohm, M., Quaini, F., Urbanek,K., Leri, A., Hintze, T.H., Kajstura, J., Anversa, P. (2005). Stem cells in the dog heart are self-renewing, clonogenic, and multipotent and regenerate infarcted myocardium, improving cardiac function. Proc. Natl. Acad. Sci. USA, 102:8966-71. 
Liu, J., Hu, Q., Wang, Z., Xu, C., Wang, X., Gong, G., Mansoor, A., Lee, J., Hou, M., Zeng, L., Zhang, J.R., Jerosch-Herold, M., Guo, T., Bache, R.J., Zhang, J. (2004). Autologous stem cell transplantation for myocardial repair. Am. J. Physiol.-Heart Circ. Physiol., 287:H501-11.

Lobe, C.G., Rudnicki, M.A., Megeney, L.A. (2002). The post-natal heart contains a myocardial stem cell population. FEBS Lett, 530:239-243.

Lu, H., Xu, X., Zhang, M., Cao, R., Brakenhielm, E., Li, C., Lin, H., Yao, G., Sun, H., Qi, L., Tang, M., Dai, H., Zhang, Y., Su, R., Bi, Y., Cao, Y. (2007). Combinatorial protein therapy of angiogenic and arteriogenic factors remarkably improves collaterogenesis and cardiac function in pigs. Proc. Natl. Acad. Sci. USA, 104:12140-5.

Lumb, G.D. (1966). Experimentally induced cardiac failure in swine: pathological changes. In Swine in Biomedical Research (ed. Bustad LK, McClellan RO), pp. 389-403. 
MacRae, C. (2010). Genetics of Cardiomyopathy and Heart Failure, Textbook.

Makkar, R.R., Price, M.J., Lill, M., Frantzen, M., Takizawa, K., Kleisli, T., Zheng, J., Kar, S., McClelan, R., Miyamota, T., Bick-Forrester, J., Fishbein, M.C., Shah, P.K., Forrester, J.S., Sharifi, B., Chen, P.S.,Qayyum, M. (2005). Intramyocardial injection of allogenic bone marrow-derived mesenchymal stem cells without immunosuppression preserves cardiac function in a porcine model of myocardial infarction. J. Cardiovasc. Pharmacol. Ther., 10:225-33.

Makela, J., Ylitalo, K., Lehtonen, S., Dahlbacka, S., Niemela, E., Kiviluoma, K., Rimpilainen, J., Alaoja, H., Paavonen, T., Lehenkari, P., Juvonen, T., Anttila, V. (2007). Bone marrow-derived mononuclear cell transplantation improves myocardial recovery by enhancing cellular recruitment and differentiation at the infarction site. J. Thorac. Cardiovasc.Surg., 134:565-73.

Martin-Rendon, E., Brunskill, S.J., Hyde, C.J., Stanworth, S.J., Mathur, A., Watt, S.M. (2008). Autologous bone marrow stem cells to treat acute myocardial infarction: a systematic review. Eur. Heart J. 29:1807-18. 
Marvin, M.J., DiRocco, G., Gardiner, A., Bush, S.M., Lassar, A.B. (2001). Inhibition of Wnt activity induces heart formation from posterior mesoderm. Genes Dev., 15:316-327.

Matoba, R., Niwa, H., Masui, S., Ohtsuka, S., Carter, M.G., Sharov, A.A. et al. (2006). Dissecting Oct3/4-regulated gene networks in embryonic stem cells by expression profiling. Plos One, issue 1, e26.

Matsuura, K., Nagai, T., Nishigaki, N., Oyama, T., Nishi, J., Wada, H. et al. (2004). Adult cardiac Sca-1-positive cells differentiate into beating cardiomyocytes. J. Biol. Chem., 279:11384-11391.

Messina, E., De Angelis, L., Frati, G., Morrone, S., Chimenti, S., Fiordaliso, F., Salio, M., Battaglia, M., Latronico, M.V., Coletta, M. et al. (2004). Isolation and expansion of adult cardiac stem cells from human and murine heart. Circ. Res. 95:911-921. 
Mezey, E., Chandross, K.J., Harta, G., Maki, R.A. and McKercher, S.R. (2000). Turning blood into brain: cells bearing neuronal antigens generated in vivo from bone marrow. Science, 290:1779-1782.

Miller-Hance, W.C., LaCorbiere, M., Fuller, S.J., Evans, S.M., Lyons, G., Schmidt, C. et al. (1993). In vitro chamber specification during embryonic stem cell cardiogenesis. Expression of the ventricular myosin light chain-2 gene is independent of heart tube formation. J. Biol. Chem., 268:25244-25252.

Minasi, M., Riminucci, M., Angelis, L.D., Borello, U., Berarducci, B., Innocenzi, A., et al. (2002). The meso-angioblast: a multipotent, self-renewing cell that originates from the dorsal aorta and differentiates into most mesodermal tissues. Development, 129:2773-2783.

Mitchell, A.J., Sabondjian, E., Sykes, J., Deans, L., Zhu, W., Lu, X., Feng, Q., Prato, F.S., Wisenberg, G. (2010). Comparison of initial cell retention and clearance kinetics after subendocardial or subepicardial injections of endothelial progenitor cells in a canine myocardial infarction model. J. Nucl. Med., 51:413-7. 
Mitsui, K., Tokuzawa, Y., Itoh, H., Segawa, K., Murakami, M. et al. (2003). The homeoprotein Nanog is required for maintenance of pluripotency in mouse epiblast and ES cells. Cell, 113:631-642.

Molkentin, J.D. and Markham, B.E. (1993). Myocyte-specific enhancerbinding factor (MEF-2) regulates alpha-cardiac myosin heavy chain gene expression in vitro and in vivo. J. Biol. Chem., 268:19512-19520.

Molkentin, J.D., Black, B.L., Martin, J.F., Olson, E.N. (1995). Cooperative activation of muscle gene expression by MEF2 and myogenic bHLH proteins. Cell, 83:1125-1136.

Moorman, A., Webb, S., Brown, N.A., Lamers, W., Anderson, R.H. (2003). Development of the heart: formation of the cardiac chambers and arterila trunks. Heart, 89:806-814. 
Moro, L., Venturino, M., Bozzo, C., Silengo, L., Altruda, F., Beguinot, L., Tarone, G. and Defilippi, P. (1998). Integrin induce activation of EGF receptor: role in MAP kinase induction and adhesion-dependent cell survival. EMBO J., 17:6622-6632.

Morrison, S.J., Kimble, J. (2006). Asymmetric and symmetric stem-cell divisions in development and cancer. Nature, 441:1068-1074.

Mukherjee, R., Brinsa, T.A., Dowdy, K.B., Scott, A.A., Baskin, J.M., Deschamps, A.M., Lowry, A.S., Escobar, G.P., Lucas, D.G., Yarbrough, W.M., Zile, M.R., Spinale, F.G. (2003). Myocardial infarct expansion and matrix metalloproteinase inhibition. Circulation, 107:618-25.

Nadal-Ginard, B., Torella, D., Ellison, G. (2006). Cardiovascular regenerative medicine at the crossroads. Clinical trials of cellular therapy must now be based on reliable experimental data from animals with characteristics similar to human's. Rev. Esp. Cardiol., 59:1175-89 
Narazaki, G., Uosaki, H., Teranishi, M., Okita, K., Kim, B., Matsuoka, S., Yamanaka, S., Yamashita, J.K. (2008). Directed and systematic differentiation of cardiovascular cells from mouse induced pluripotent stem cells. Circulation, 118:498-506.

Nygren, J.M., Jovinge, S., Breitbach, M., Sawen, P., Roll, W., Hescheler, J., Taneera, J., Fleischmann, B.K. and Jacobsen, S.E. (2004). Bone marrowderived hematopoietic cells generate cardiomyocytes at a low frequency through cell fusion, but not transdifferentiation. Nat. Med., 10:494-501.

Nishimoto, M., Fukushima, A., Okuda, A., Muramatsu, M. (1999). The gene for the embryonic stem cell coactivator UTF1 carries a regulatory element which selectively interacts with a complex composed of Oct-3/4 and Sox-2. Mol. Cell. Biol., 19:5453-5465.

Niwa, H., Miyazaki, J., Smith, A.G. (2000). Quantitative expression of Oct-3/4 defines differentiation, dedifferentiation or self-renewal of ES cells. Nat. Genet., 24:372-376. 
Niwa, H. (2001). Molecular mechanism to maintain stem cell renewal of ES cells. Cell Struct. Funct., 26:137-148.

Nussbaum, J. (2007). Transplantation of undifferentiated murine embryonic stem cells in the heart: teratoma formation and immuneresponse. FASEB J., 21:1345.

O’Konski, M.S., White, F.C., Longhurst, J., Roth, D., and Bloor, C.M. (1987). Ameroid constriction of the proximal left circumflex coronary artery in swine. A model of limited coronary collateral circulation. Am. J. Cardiovasc. Pathol., $1: 69-77$

Oh, H., Bradfute, S., Gallardo, T., Nakamura, T., Gaussin, V., Mishina, Y. et al. (2003). Cardiac progenitor cells from adult myocardium: homing, differentiation, and fusion after infarction. Proc. Natl. Acad. Sci. USA, 100:12313-12318. 
Ojaniemi, M., V. Glumoff, K. Harju, M. Liljeroos, K. Vuori, and M. Hallman. (2003). Phosphatidylinositol 3-kinase is involved in Toll-like receptor 4mediated cytokine expression in mouse macrophages. Eur. J. Immunol. 33:597-605.

Orlic, D., Kajstura, J., Chimenti, S., Jakoniuk, I., Anderson, S.M., Li, B., Pickel, J., McKay, R., Nadal-Ginard, B., Bodine, D.M. et al. (2001). Bone marrow cells regenerate infarcted myocardium. Nature, 410:701-705.

Pak, H.N., Qayyum, M., Kim, D.T., Hamabe, A., Miyauchi, Y., Lill, M.C., Frantzen, M., Takizawa, K., Chen, L.S., Fishbein, M.C., Sharifi, B.G., Chen, P.S., Makkar, R. (2003). Mesenchymal stem cell injection induces cardiac nerve sprouting and increased tenascin expression in a Swine model of myocardial infarction. J. Cardiovasc. Electrophysiol., 14:841-8.

Pandolfi, P.P., Roth, M.E., Karis, A., Leonard, M.W., Dzierzak, E., Grosveld, F.G., Engel, J.D., Lindenbaum, M.H. (1995). Targeted disruption of the GATA3 gene causes severe abnormalities in the nervous system and in fetal liver haematopoiesis. Nature Genet., 11:40-44. 
Pardanaud, L. and Eichmann A. (2006). Identification, emergence and mobilization of circulating endothelial cells or progenitors in the embryo. Development, 133:2527-2537.

Passier, R., van Laake, L.W., Mummery, C.L. (2008). Stem-cell-based therapy and lessons from the heart. Nature, 453:322-9.

Patthy, L. (1990). Homology of a domain of the growth hormone/prolactin receptor family with type 3 modules of fibronectin. Cell, 61:13-14.

Perez-Pomares, J.M., Mironov, V., Guadix, J., Macias, D., Markwald, R. and Munoz-Chapuli, R. (2006). In vitro self-assembly of proepicardial cell aggregates: an embryonic vasculogenic model for vascular tissue engineering. Anat. Rec. Part A, 288A:700-713.

Pesce, M. and Schöler, H.R. (2001). Oct-4: gatekeeper in the beginnings of mammalian development. Stem Cells, 19:271-278. 
Peterkin, T., Gibson, A., Patient, R. (2003). GATA-6 maintains BMP-4 and Nkx2.5 expression during cardiomyocyte precursor maturation. EMBO J., 19:3683-3693.

Pfister, O., Mouquet, F., Jain, M., Summer, R., Helmes, M., Fine, A., Colucci, W.S. and Liao, R. (2005). CD31- but Not CD31+ cardiac side population cells exhibit functional cardiomyogenic differentiation. Circ. Res., 97:52-61.

Pittenger, M.F., Mackay, A.M., Beck, S.C., Jaiswal, R.K., Douglas, R., Mosca, J.D., Moorman, M.A., Simonetti, D.W., Craig, S., Marshak, D.R. (1999). Multilineage potential of adult human mesenchymal stem cells. Science, 284:143-7.

Pittenger, M.F. and Martin B.J. (2004). Mesenchymal stem cells and their potential as cardiac therapeutics. Circ. Res., 95:9-20.

Plageman, F.T., Yutzey, Jr. and K.E. (2005). T-Box Genes and Heart Development: Putting the " $T$ " in Heart. Developmental Dynamics, 232:11-20. 
Poh, K.K., Sperry, E., Young, R.G., Freyman, T., Barringhaus, K.G., Thompson, C.A. (2007). Repeated direct endomyocardial transplantation of allogeneic mesenchymal stem cells: safety of a high dose, "off-the-shelf", cellular cardiomyoplasty strategy. Int. J. Cardiol., 117:360-4.

Potthoff, M.J. and Olson, E.N. (2007). MEF2: a central regulator of diverse developmental programs. Development, 134:4131-4140.

Quesenberry, P.J., Becker, P.S. (1998). Stem cell homing: rolling, crawling, and nesting. Proc. Natl. Acad. Sci. USA, 95:15155-15157.

Rajala, K., Pekkanen-Mattila, M., Aalto-Setala, K. (2011). Cardiac differentiation of pluripotent stem cells. Stem Cells Int., 383709.

Reinecke, H., Poppa, V., Murry, C.E. (2002). Skeletal muscle stem cells do not transdifferentiate into cardiomyocytes after cardiac grafting. J. Mol. Cell Cardiol., 34:241-9. 
Ryan, K., Chin, A.J. (2003). T-box genes and cardiac development. Birth Defects Res. Part C Embryo Today, 69:25-37.

Ribatti, D., Urbinati, C., Nico, B., Rusnati, M., Roncali, L., Presta, M. (1995). Endogenous basic fibroblast growth factor is implicated in the vascularization of the chick embyo. Dev. Biol., 170:39-49.

Risau, W., Sariola, H., Zerwes, H.G., Sasse, J., Ekblom, P., Kemler, R. (1988). Vasculogenesis and angiogenesis in embryonic stem cell derived embryoid bodies. Development, 102:471-478.

Rose, R.A., Keating, A., Backx, P.H. (2008). Do mesenchymal stromal cells transdifferentiate into functional cardiomyocytes? Circ. Res., 103:e120.

Rossi, D.J., Jamieson, C.H., Weissman, I.L., (2008). Stem cells and the pathways to aging and cancer. Cell, 132:681-96. 
Rota, M., Padin-Iruegas, M.E., Misao, Y., De Angelis, A., Maestroni, S., Ferreira-Martins, J., Fiumana, E., Rastaldo, R., Arcarese, M.L., Mitchell, T.S., Boni, A., Bolli, R., Urbanek, K., Hosoda, T., Anversa, P., Leri, A., Kajstura, J. (2008). Local activation or implantation of cardiac progenitor cells rescues scarred infarcted myocardium improving cardiac function. Circ. Res., 103:107116.

Roth, D.M., Maruoka, Y., Rogers, J., White, F.C., Longhurst, J.C. and Bloor, C.M. (1987). Development of coronary collateral circulation in left circumflex ameroid-occluded swine myocardium. Am. J. Physiol. Heart Circ. Physiol., 253:H1279-H1288.

Saga, Y., Miyagawa-Tomita, S., Takagi, A., Kitajima, S., Miyazaki, J., Inoue, T. (1999). MesP1 is expressed in the heart precursor cells and required for the formation of a single heart tube. Development, 126:3437-3447. 
Sales, V.L., Mettler, B.A., Engelmayr, G.C.Jr., Aikawa, E., Bischoff, J., Martin, D.P., Exarhopoulos, A., Moses, M.A., Schoen, F.J., Sacks, M.S., Mayer, J.E.Jr. (2010). Endothelial progenitor cells as a sole sourcefor ex vivo seeding of tissue-engineered heart valves. Tissue Eng. Part A, 16:257-67.

Sartore, S., Lenzi, M., Angelini, A., Chiavegato, A., Gasparotto, L., De Coppi, P., Bianco, R., Gerosa, G. (2005). Amniotic mesenchymal cells autotransplanted in a porcine model of cardiac ischemia do not differentiate to cardiogenic phenotypes. Eur. J. Cardiothorac. Surg., 28:677-84.

Savatier, P., Lapillonne, H., van, Grunsven, L.A., Rudkin, B.B., Samarut, J. (1996). Withdrawal of differentiation inhibitory activity/leukemia inhibitory factor up-regulates D-type cyclins and cyclin-dependent kinase inhibitors in mouse embryonic stem cells. Oncogene, 12:309-322.

Schratt, G., Weinhold, B., Lundberg, A.S., Schuck, S., Berger, J., Schwarz, H., Weinberg, R.A., Ruther, U. and Nordheim, A. (2001). Serum response factor is required for immediate-early gene activation yet is dispensable for proliferation of embryonic stem cells. Mol. Cell. Biol., 21:2933-2943. 
Schlange, T., Adree, B., Arnold, HH., Brand, T. (2000). BMP-2 is required for early heart development during a distinct time period. Mech. Dev., 91:258-270.

Schofield, J.D., and Weightman, B. (1978). New knowledge of connective tissue ageing. Journal of Clinical Pathology, 31, Supplement (Royal College of Pathologists), 12:174-190.

Schuleri, K.H., Feigenbaum, G.S., Centola, M., Weiss, E.S., Zimmet, J.M., Turney, J., Kellner, J., Zviman, M.M., Hatzistergos, K.E., Detrick, B., Conte, J.V., McNiece, I., Steenbergen, C., Lardo, A.C., Hare, J.M. (2009). Autologous mesenchymal stem cells produce reverse remodeling in chronic ischaemic cardiomyopathy. Eur. Heart J., 30:2722-32.

Schultheiss, T.M., Burch, J.B., Lassar, A.B. (1997). A role of bone morphogenetic proteins in the induction of cardiac myogenesis. Genes Dev., $11: 451-462$. 
Schwartz, R.J. and Olson, E.N. (1999). Building the heart piece by piece: modulatory of cis-elements regulating Nkx2.5 transcription. Development, $126: 4187-4192$.

Scott, F.G. (1997). Developmental Biology, Sinauer Associates Inc. 917 pp.

Searcy, R.D., Vincent, E.B., Liberatore, C.M., Yutzey, K.E. (1998). A GATAdependent Nkx2.5 regulatory element activates early cardiac gene expression in transgenic mice. Development, 125:4461-4470.

Secker, G.A. and Daniels J.T. (2009). Limbal epithelial stem cells of the cornea.

Segers, V.F. and Lee, R.T. (2008). Stem-cell therapy for cardiac disease. Nature, 451:937-42.

Sherr, C.J. and Roberts, J.M. (1995). Inhibitors of mammalian $G_{1}$ cyclindependent kinases. Genes \& Dev., 9:1149-1163. 
Silva, G.V., Litovsky, S., Assad, J.A., Sousa, A.L., Martin, B.J., Vela, D., Coulter, S.C., Lin, J., Ober, J., Vaughn, W.K., Branco, R.V., Oliveira, E.M., He, R., Geng, Y.J., Willerson, J.T., Perin, E.C. (2005). Mesenchymal stem cells differentiate into an endothelial phenotype, enhance vascular density, and improve heart function in a canine chronic ischemia model. Circulation, 111:150-6.

Smart, N. and Riley, P.R. (2009). Derivation of epicardium-derived progenitor cells (EPDCs) form adult epicardium. Somatic Stem Cells, 2C.2.1 supplement 8.

Smart, N., Bollini, S., Dubé, K.N., Vieira, J.M., Zhou, B., Davidson, S. et al. (2011). De novo cardiomyocytes from within the activated adult heart after injury. Nature, doi:10.1038.

Smith, R.R., Barile, L., Cho, H.C., Leppo, M.K., Hare, J.M., Messina, E.,Giacomello, A., Abraham, M.R., Marban, E. (2007). Regenerative potential of cardiosphere-derived cells expanded from percutaneous endomyocardial biopsy specimens. Circulation, 115:896-908. 
Srinivasan, V. (2011). A method to fix and permeabilize isolated adult mouse cardiomyocytes for immuno-staining and confocal imaging. Protocol Exchange, doi:10.1038/protex.2011.235.

Stull, L.B., Leppo, M.K., Marban, E., Janssen, P.M. (2002). Physiological determinants of contractile force generation and calcium handling in mouse myocardium. J. Mol. Cell. Cardiol., 34:1367-1376.

Sussman, M. (2001). Cardiovascular biology. Hearts and bone. Nature, 410:640-641.

Sutherland, F.W., Perry, T.E., Yu, Y., Sherwood, M.C., Rabkin, E., Masuda, Y., Garcia, G.A., McLellan, D.L., Engelmayr, G.C.Jr., Sacks, M.S., Schoen, F.J., Mayer, J.E.Jr. (2005). From stem cells to viable autologous semilunar heart valve. Circulation, 111:2783-91.

Swynghedauw, B. (1986). Developmental and functional adaptation of contractile proteins in cardiac and skeletal muscles. Physiol. Rev., 66:710-71. 
Taga, T. and Kishimoto, T. (1997). gp130 and the interleukin-6 family of cytokine. Annu. Rev. Immunol., 15:797-819.

Tallini, Y.N., Greene, K.S., Craven, M., Spealman, A., Breitbach, M., Smith, J., Fisher, P.J., Steffey, M., Hesse, M., Doran, R.M., Woods, A., Singh, B., Yen, A., Fleischmann, B.K. and Kotlikoff, M.I. (2009). c-kit expression identifies cardiovascular precursors in the neonatal heart. Proc. Natl. Acad. Sci. USA, 106:1808-1013.

Tanaka, M., Tickle, C. (2004). Tbx18 and boundary formation in chick somite and wing development. Dev. Biol., 268:470-480.

Theunissen, T.W. and Silva, J.C.R. (2011). Switching on pluripotency: a perspective on the biological requirement of Nanog. Philos. Trans., 366:22222229. 
Tokuzawa, Y., Kaiho, E., Maruyama, M., Takahashi, K., Mitsui, K., Maeda, M., Niwa, H., Yamanaka, S. (2003). Fbx15 is a novel target of Oct3/4 but is dispensable for embryonic stem cell self-renewal and mouse development. Mol Cell Biol., 23:2699-2708.

Tomita, Y., Matsumura, K., Wakamatsu, Y., Matsuzaki, Y., Shibuya, I., Kawaguchi, H., Ieda, M., Kanakubo, S., Shimazaki, T., Ogawa, S. et al. (2005). Cardiac neural crest cells contribute to the dormant multipotent stem cell in the mammalian heart. J. Cell Biol., 170:1135-1146.

Torella, D., Ellison, G.M., Nadal-Ginard, B. and Indolfi, C. (2005). Cardiac stem and progenitor cell biology for regenerative medicine. Trends Cardiovasc. Med., 15:229-236.

Torella, D., Ellison, G., Karakikes, I., Nadal-Ginard, B. (2006). The cardiac stem cell: the adult mammalian heart harbours Oct4pos cardiac stem cells with very broad developmental potential. Circulation, 114:II_303. 
Torella, D., Ellison, G., Karakikes, I., Nadal-Ginard, B. (2007). Growth-factormediated cardiac stem cell activation in myocardial regeneration. Nat. Clin. Pract. Cardiovasc. Med., 4 Supplement 1, S46-51.

Tsai, F.Y., Keller, G., Kuo, F.C., Weiss, M., Chen, J., Rosenblatt, M. (1994). An early haematopoietic defect in mice lacking the transcription factor GATA-2. Nature, 371:221-226.

Urbanek, K., Cesselli, D., Rota, M., Nascimben, A., De Angelis, A., Hosoda, T., Bearzi, C., Boni, A., Bolli, R., Kajstura, J., Anversa, P., Leri, A. (2006). Stem cell niches in the adult mouse heart. Proc. Natl. Acad. Sci. USA, 103:92269231.

Vailhé, B., Vittet, D., Feige, J.J. (2001). In vitro models of vasculogenesis and angiogenesis. Lab. Invest., 81:439-451. 
Valina, C., Pinkernell, K., Song, Y.H., Bai, X., Sadat, S., Campeau, R.J., Le Jemtel, T.H., Alt, E. (2007). Intracoronary administration of autologous adipose tissue-derived stem cells improves left ventricular function, perfusion, and remodelling after acute myocardial infarction. Eur. Heart J., 28:2667-77.

van Tuyn, J., Atsma, D.E., Winter, E.M., van der Velde-van Dijke, I.,Pijnappels, D.A., Bax, N.A., Knaan-Shanzer, S., Gittenberger-deGroot, A.C., Poelmann, R.E., van der Laarse, A., van der Wall, E.E., Schalij, M.J., de Vries, A.A. (2007). Epicardial cells of human adults can undergo an epithelialto-mesenchymal transition and obtain characteristics of smooth muscle cells in vitro. Stem Cells, 25:271-8.

Vanhaesebroeck, B. and Alessi, D.R. (2000). The PI3K-PDK1 connection: more thanjust a road to PKB. Biochem. J., 346 Pt 3:561-756. 
Vincentelli, A., Wautot, F., Juthier, F., Fouquet, O., Corseaux, D., Marechaux, S., Le Tourneau, T., Fabre, O., Susen, S., Van Belle, E., Mouquet, F., Decoene, C., Prat, A., Jude, B. (2007). In vivo autologous recellularization of a tissueengineered heart valve: are bone marrow mesenchymal stem cells the best candidates? J. Thorac. Cardiovasc. Surg., 134:424-32.

Vikkula, M., Boom, L.M., Carraway, K.L., Calvert, J.T., Diamonti, A.J., Goumnerov, B. et al. (1996). Vascular dysmorphogenesis caused by an activating mutation in the receptor tyrosine kinase Tie2. Cell, 87:1181-1190.

Vulliet, P.R., Greeley, M., Halloran, S.M., MacDonald, K.A., Kittleson, M.D. (2004). Intra-coronary arterial injection of mesenchymal stromal cells and microinfarction in dogs. Lancet, 363:783-4.

Zaruba, M.M., Soonpaa, M., Reuter, S., Field, L.J. (2010). Cardiomyogenic potential of $\mathrm{c}-\mathrm{kit}^{+}-$expressing cells derived from neonatal and adult mouse hearts. Circulation, 121:1992-2000. 
Zeisberg, E.M., Tarnavski, O., Zeisberg, M., Dorfman, A.L., McMullen, J.R., Gustafsson, E., Chandraker, A., Yuan, X., Pu, W.T., Roberts, A.B., Neilson, E.G., Sayegh, M.H., Izumo, S., Kalluri, R. (2007). Endothelial-to-mesenchymal transition contributes to cardiac fibrosis. Nat. Med., 13:952-61.

Zhou, B., Pu, W.T. (2008). More than a cover: epicardium as a novel source of cardiac progenitor cells. Regen. Med., 3:633-635.

Zhou, B., Ma, Q., Rajagopal, S., Wu, S.M., Domian, I., Rivera-Feliciano, J. et al. (2008). Epicardial progenitors contribute to the cardiomyocyte lineage in the developing heart. Nature, 454:109-113.

Weaver, M.E., Pantely, G.A., Bristow, J.D., Ladley, H.D. (1986). A quantitative study of the anatomy and distribution of coronary arteries in swine in comparison with other animals and man. Cardiovasc. Res., 20:907-17. 
Weir, C., Morel-Kopp, M.C., Gill, A., Tinworth, K., Ladd, L., Hunyor, S.N., Ward,C. (2008). Mesenchymal stem cells: isolation, characterisation and in vivo fluorescent dye tracking. Heart Lung Circ., 17:395-403.

Whyatt, D.J., DeBoer, E., Grosveld, F. (1993). The two zinc finger-like domains of GATA-1 have different DNA binding specificities. EMBO J., 12:4993-5005.

White, F.C., Roth, D.M., Bloor, C.M. (1986). The pig as a model for myocardial ischemia and exercise. Lab. Anim. Sci., 36:351-6.

Wianny, F., Real, F.X., Mummery, C.L., Van Rooijen, M., Lahti, J., Samarut, J. and Savatier, P. (1998). G1-phase regulators, cyclin D1, cyclin D2, and cyclin D3: up-regulation at gastrulation and dynamic expression during neurulation. Dev. Dyn., 212:49-62. 
Yan, P., Nagasawa, A., Uosaki, H., Sugimoto, A., Yamamizu, K., Teranishi, M., Matsuda, H., Matsuoka, S., Ikeda, T., Komeda, M., Sakata, R., Yamashita, J.K. (2009). Cyclosporin-A potently induces highly cardiogenic progenitors from embryonic stem cells. Biochem. Biophys. Res. Commun., 379:115-20.

Yoon, P.D., Kao, R.L., Magovern, G.J. (1995). Myocardial regeneration. Transplanting satellite cells into damaged myocardium. Tex. Heart Inst. J., 22:119-25.

Yoon, B.S., Yoo, S.J., Lee, J.E., You, S., Lee, H.T., Yoon, H.S. et al. (2006). Enhanced differentiation of human embryonic stem cells into cardiomyocytes by combining hanging drop culture and 5-azacytidine treatment. Differentiation, 74:149-159.

Young, D.A., Dequach, J.A., Christman, K.L. (2010). Human cardiomyogenesis and the need for systems biology analysis. WIREs Systems Biology and Medicine, 3:666-680. 
Yuan, H., Corbi, N., Basilico, C., Dailey, L. (1995). Developmental-specific activity of the FGF-4 enhancer requires the synergistic action of Sox 2 and Oct-3. Genes Dev., 9:2635-2645.

Yuasa, S., Itabashi, Y., Koshimizu, U., Tanaka, T., Sugimura, K., Kinoshita, M., Hattori, F., Fukami, S., Shimazaki, T., Ogawa, S., Okano, H., Fukuda, K. (2005). Transient inhibition of BMP signaling by Noggin induces cardiomyocyte differentiation of mouse embryonic stem cells. Nat. Biotechnol., 23:607-611.

Yutzey, K.E. and Robbins, J. (2007). Principles of genetic murine models for cardiac disease. Circulation, 115:792-9.

Zaruba, M.M., Soonpaa, M., Reuter, S., Field, L.J. (2010). Cardiomyogenic potential of $\mathrm{c}-\mathrm{kit}^{+}-$expressing cells derived from neonatal and adult mouse hearts. Circulation, 121:1992-2000. 
Zhang, Y.M., Hartzell, C., Narlow, M., Dudley, S.C. (2002). Stem cell-derived cardiomyocytes demonstrate arrhythmic potential. Circulation, 106:1288-1293.

Zhu, A.J., Haase, I. and Watt, F.M. (1999). Signalling via b1 integrins and mitogen-activated protein kinase determines human epidermal stem cell fate in vitro. Proc. Natl. Acad. Sci. USA, 96:6728-6733.

Wainwright, J.M., Czajka, C.A., Patel, U.B., Freytes, D.O., Tobita, K., Gilbert, T.W. (2010). Preparation of cardiac extracellular matrix from an intact porcine heart. Tissue Eng. Part C Methods, 16:525-32.

Weeke-Klimp, A., Bax, N.A., Bellu, A.R., Winter, E.M., Vrolijk, J., Plantinga, J., Maas, S., Brinker, M., Mahtab, E.A., et al. (2010). Epicardium-derived cells enhance proliferation, cellular maturation and alignment of cardiomyocytes. Journal of Molecular and Cellular Cardiology, 49:606-616.

White, D. and Wallwork, J. (1993). Xenografting: probability, possibility, or pipe-dream?Lancet,342:879-880. 


\section{Appendix}

a) Gandolfi, F., Vanelli, A., Pennarossa, G., Rahaman, M., Acocella, F., Brevini, T.A.L. (2011). Large animal models for cardiac stem cell therapies. Theriogenology, 75:1416-25.

b) Vanelli, A., Pennarossa, G., Maffei, S., Galvez, G.B., Cossu, G., Rahaman, M., Gandolfi, F., Brevini, T.A.L. (2011). Isolation, characterization and differentiation potential of cardiac progenitor cells in adult pigs. Stem Cell Rev. and Rep. (accepted). 


\section{Acknowledgements}

I would like to take this opportunity to thank those who made this work possible.

First and foremost, I offer my sincerest gratitude to my supervisor, Professor Tiziana Brevini, who has supported me throughout my thesis with her patience, knowledge and giving me always valuable advice and offering its maximum willingness.

I also owe my deepest gratitude to Professor Fulvio Gandolfi for welcoming me into his laboratory and for leading my professional growth to levels that alone I couldn't have ever reach.

I would like to thank my parents for their unconditional support, both financially and emotionally, throught my $\mathrm{PhD}$. In particular, the patience and understanding shown by my mum, dad and sister during these three years were essential to allow me to completing this work. 
To my boyfriend, Emanuele Canziani, I wish to offer my deepest thanks. He was and is a solid anchor on which I rely again and again. Words can not express how grateful I am to be in his life and how much this work was enhanced and made easier by him being in mine.

There are many others I should mention here. People who helped me along the way and provided me support when I didn't even realize I needed it. Listing all of them would fill a book itself, so I merely will have to limit myself to a few words:

THANKS TO ALL 